\begin{abstract}
UNIVERSIDADE DE SÃO PAULO
FACULDADE DE FILOSOFIA, LETRAS E CIÊNCIAS HUMANAS DEPARTAMENTO DE LETRAS CLÁSSICAS E VERNÁCULAS MESTRADO PROFISSIONAL EM LETRAS EM REDE NACIONAL
\end{abstract}

TICIANA LOSANO

Estratégias de leitura no ensino de língua portuguesa: a observação das escolhas lexicais e seu efeito de sentido nos contos de Lygia Fagundes Telles 


\author{
UNIVERSIDADE DE SÃO PAULO \\ FACULDADE DE FILOSOFIA, LETRAS E CIÊNCIAS HUMANAS \\ DEPARTAMENTO DE LETRAS CLÁSSICAS E VERNÁCULAS \\ MESTRADO PROFISSIONAL EM LETRAS EM REDE NACIONAL
}

Estratégias de leitura no ensino de língua portuguesa:

a observação das escolhas lexicais e seu efeito de sentido nos contos de Lygia Fagundes Telles

\title{
Ticiana Losano
}

\begin{abstract}
Dissertação apresentada ao Programa de Mestrado Profissional em Letras em Rede Nacional do Departamento de Letras Clássicas e Vernáculas da Faculdade de Filosofia, Letras e Ciências Humanas da Universidade de São Paulo.
\end{abstract}

Orientadora: Prof. ${ }^{a}$ Dr. ${ }^{a}$ Elis de Almeida Cardoso Caretta 
A todos aqueles que acreditam no poder transformador da educação 


\section{AGRADECIMENTOS}

À CAPES, pela concessão da bolsa de mestrado, que trouxe o suporte financeiro necessário durante minha trajetória estudantil e possibilitou a realização desta pesquisa.

À minha orientadora, Prof. ${ }^{\underline{a}}$ Dr. ${ }^{\text {a }}$ Elis de Almeida Cardoso Caretta, por sua paciência e carinho, pelas conversas e sugestões, por sua visão experiente e crítica, por toda sua dedicação e imensa contribuição em minha vida acadêmica e profissional.

À Prof. ${ }^{\underline{a}}$ Dr. ${ }^{\underline{a}}$ Maria Helena da Nóbrega e à Prof. ${ }^{\underline{a}}$ Dr. ${ }^{\underline{a}}$ Alessandra Ferreira Ignez, pelo tempo investido e atenção dedicada na leitura de meu trabalho e pelas preciosas contribuições dadas no exame de qualificação.

A todos os docentes envolvidos no processo de implantação do Mestrado Profissional em Letras (PROFLETRAS), cujos ideais para realização desse curso me inspiraram para concretização deste trabalho e, principalmente, para exercer uma prática educativa mais consciente.

Às unidades escolares em que trabalhei durante a realização do curso, que sempre me apoiaram e contribuíram para que este trabalho fosse concluído.

À minha família, por toda paciência e compreensão.

Finalmente, para meus queridos alunos, que me inspiram, a cada dia, a ser uma professora melhor, e por me mostrar que todo o esforço e dedicação valem a pena. 
O texto, assim como o tapete, é um chamariz. Juntamente com o protagonista do conto, o leitor pouco a pouco vai sendo seduzido pela cena de caça bordada no tapete, vai se aproximando das figuras ali desenhadas, corroído pela incerteza de saber se é caçador ou a caça, até abandonar-se àquele tempo/espaço e se distanciar de si mesmo, absorto na contemplação, completamente esquecido de sua identidade e pronto para se fundir nas malhas daquele imaginário. Imaginário mais concreto do que a própria página do livro. $\mathrm{O}$ bom texto literário exige esse deslocamento do leitor, assim como a cena do tapete exerce seu chamado sobre o protagonista. Ambos, protagonista e leitor, atravessam o espaço tênue que separa a realidade da representação, trilhando a própria urdidura de fios e traços à sua frente para o confronto com outra realidade. Essa é a tradição da narrativa, o aprisionamento do leitor, uma qualidade que os textos da autora mantêm de modo admirável.

Sônia Régis - $A$ densidade do aparente 


\section{RESUMO}

A presente pesquisa tem por objetivo elaborar uma proposta de ensino de língua portuguesa que vise direcionar alunos do $9^{\circ}$ ano do Ensino Fundamental II a aplicar estratégias de leitura tendo como foco o texto literário, mais especificamente a estratégia de observar as escolhas lexicais realizadas por um escritor, para que possam fazer uso dessas observações na interpretação textual. Para isso, partimos da análise das escolhas lexicais de Lygia Fagundes Telles, observando o papel dos recursos expressivos encontrados em três contos da autora: Natal na Barca, Verde Lagarto Amarelo e A caçada. Procurou-se dar ênfase ao papel das palavras que exercem função caracterizadora na construção de elementos descritivos nos contos literários estudados. Com base na análise estabelecida, apontam-se direcionamentos para a prática pedagógica, que visem repensar o ensino da língua presente nos currículos escolares atualmente, buscando-se observar estratégias do ensino da leitura que refletem sobre questões linguísticas, discursivas e estéticas do texto. $\mathrm{Na}$ análise dos contos, procurou-se mostrar como a construção da caracterização do ambiente e das personagens por meio das escolhas lexicais ajuda a criar a atmosfera do texto, imprimindo uma imagem que se agrega à produção de efeitos de sentido, assim como a averiguar como os elementos expressivos no texto podem colaborar com seu entendimento, possibilitando leitura crítica e apreciação estética. Para se atingir o objetivo proposto, esta pesquisa se baseou na Morfologia, na Lexicologia, na Estilística e na Semântica, tanto para a análise do corpus quanto para a elaboração da sequência didática. Após a aplicação da sequência didática em sala de aula, verificou-se que os estudantes têm dificuldade em sistematizar conceitos gramaticais e utilizá-los na análise textual. Pôde-se observar, ainda, que quando existe uma estratégia clara e delineada para o aluno, este pode ser conduzido a compreender um texto com mais autonomia.

Palavras-chave: conto; Lygia Fagundes Telles; escolhas lexicais; estratégia de leitura; ensino. 


\section{ABSTRACT}

This research aims to develop a Portuguese Language teaching proposal to direct students of 9th grade of elementary school to apply for reading strategies focusing on literary text, specifically the strategy to observe the lexical choices made by a writer, so that they can make use of these observations in textual interpretation. For this, we start from the analysis of lexical choices of Lygia Fagundes Telles, noticing the role of some expressive resources found in three short-stories by the author: Natal na barca, Verde lagarto amarelo and $A$ caçada. The study of these short-stories tries to emphasize the role of words which have important functions in the construction of descriptive elements in the literary texts. The established analysis intends to give some directions to the pedagogical practice, rethinking the teaching of this language in school curriculum, seeking for reading and teaching strategies that could reflect on language, discursive and aesthetic issues in the text. In the analysis of the short-stories, we tried to show how the construction of the characterization of the environment and the characters help to create the atmosphere of the text. Resulting on an image that adds to the meaning of the text and its impression effect, and also find out how the expressive elements in the text can collaborate with their understanding, enabling critical reading abilities and aesthetic appreciation. To achieve this purpose, this research was based on Morphology, Lexicology, Stylistics and Semantics for the analysis of the corpus and also for the elaboration of didactic sequence applied in the classroom. After the research application in the classroom, it was found that students have difficulty in systematize grammatical concepts and use them in textual analysis. It was also observed that when there is a clear and definite strategy for the student, it can leads to understand the text with more autonomy.

Keywords: short-story, Lygia Fagundes Telles, lexical choices, reading strategy, instruction. 


\section{SUMÁRIO}

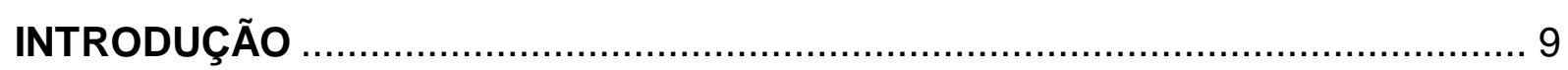

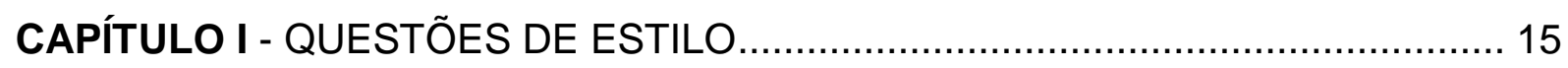

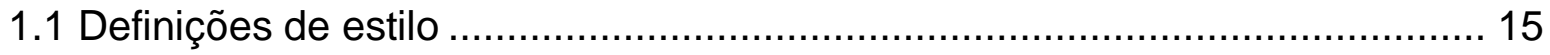

$1.2 \mathrm{O}$ estilo de Lygia Fagundes Telles .......................................................... 17

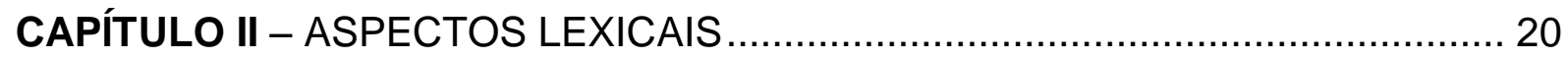

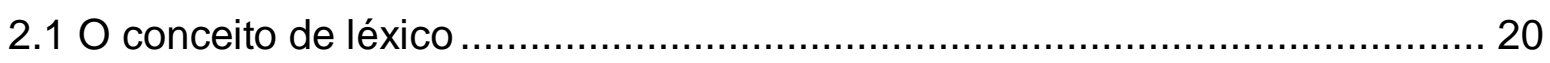

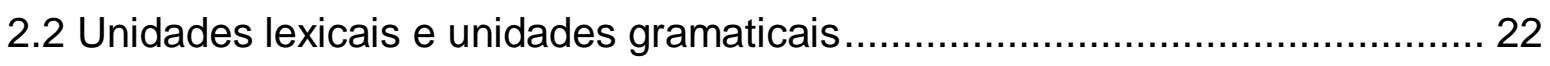

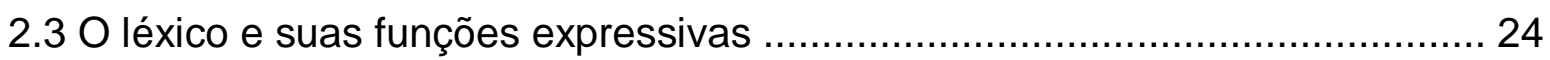

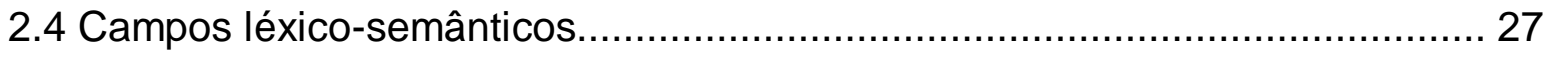

CAPÍTULO III - PALAVRAS COM FUNÇÃO CARACTERIZADORA........................ 30

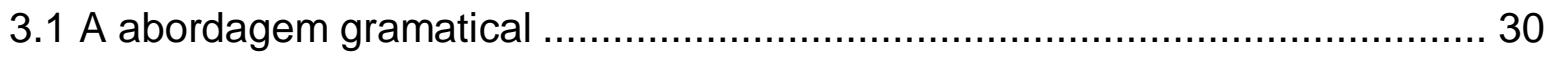

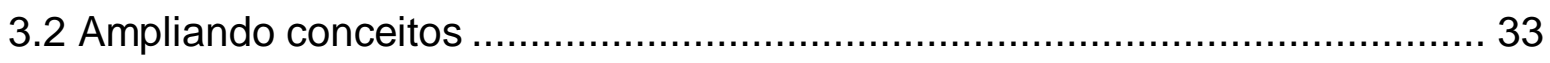

CAPÍTULO IV - ENCAMINHAMENTOS DIDÁTICOS: O CONTO EM CENA .......... 41

4.1 Definição do conto e suas características .................................................... 41

4.2 A Caçada: Caçando... Ou sendo caçado? ................................................... 48

4.3 Verde Lagarto Amarelo: a disputa entre irmãos .......................................... 54

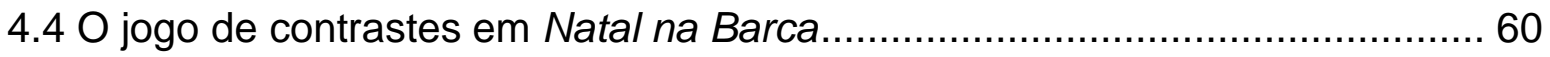

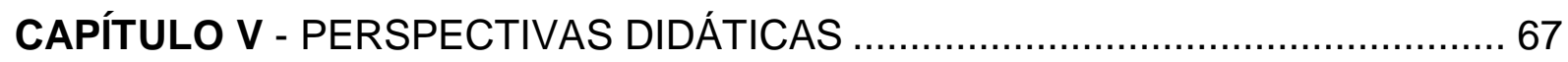

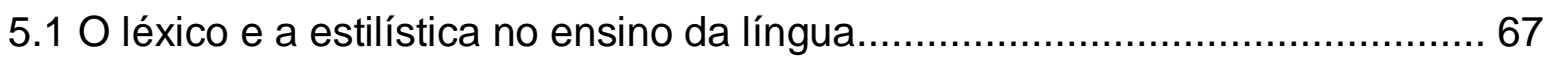

5.2 A leitura e a compreensão do texto ......................................................... 71

5.2.1 Uma proposta de leitura dos contos de Lygia Fagundes Telles em sala de

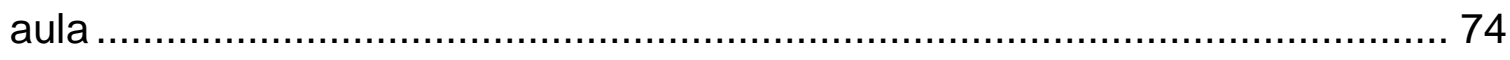

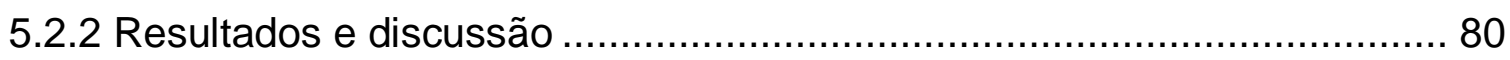

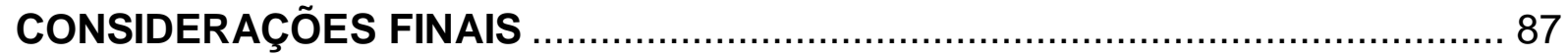

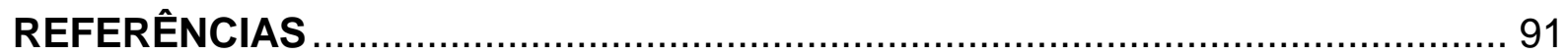

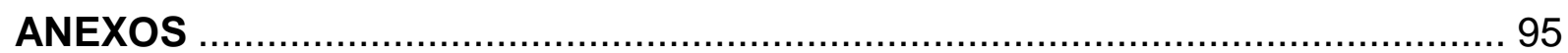




\section{INTRODUÇÃO}

A educação, assim como a sociedade, tem, ao longo dos anos, passado por significantes transformações, o que também se verifica com o ensino de Língua Portuguesa. Segundo Rojo (2008), o ensino da língua portuguesa esteve pautado, por muito tempo, na gramática histórica e normativa. Somente nas décadas de 1960 e 1970, com a democratização do ensino, a língua portuguesa passou a ser trabalhada na escola como instrumento de comunicação e expressão da cultura brasileira.

Ainda assim, na década de 1980 , o texto era usado como pretexto para o ensino das regras gramaticais (GERALDI, 1984). Somente na década de 1990, com o avanço das novas tecnologias, a discussão contra um ensino escolarizado e descontextualizado se intensifica. A partir disso, muitos documentos são elaborados - dentre eles os Parâmetros Curriculares Nacionais (PCN) -, a fim de promover debates sobre a função da escola: o que ensinar e para que ensinar.

Desvencilhar-se da herança conteudista que por tantos anos guiou os currículos escolares, entretanto, não tem sido tarefa fácil. Muitos alunos ainda alegam não conseguir vincular os conteúdos ministrados em sala de aula com atividades práticas. No caso da disciplina de Língua Portuguesa, não parecem conseguir transportar os aprendizados supostamente adquiridos a contextos de análise, de interpretação ou de produção escrita. Na última década, resultados de avaliações do ensino têm mostrado que o nível de aprendizagem dos estudantes brasileiros não é satisfatório. É o caso do Programa Internacional de Avaliação de Estudantes (PISA), por exemplo. O PISA avalia os alunos na área de leitura, matemática e ciências. Em leitura é avaliada a "capacidade de um indivíduo de entender, empregar e refletir sobre textos escritos, para alcançar objetivos, desenvolver conhecimentos e participar da sociedade"1. Na última avaliação do PISA, cuja ênfase foi dada à leitura, observou-se que o Brasil ocupa a 53a posição em um ranking de 65 países, sendo que $59,4 \%$ dos alunos apresentam baixo índice de proficiência.

${ }^{1}$ http://download.inep.gov.br/acoes internacionais/pisa/documentos/2012/relatorio nacional pisa 200 9.pdf, p.19. 
O atual quadro da educação brasileira mostra que, apesar dos anos de escolarização, os alunos não apresentam habilidades suficientes para compreender um texto além de sua simples decodificação. Portanto a presente pesquisa se justifica na necessidade da adoção de novas propostas de ensino que visem trabalhar com o texto de forma que os discentes possam compreendê-lo de maneira perspicaz, observando os fatores linguísticos que contribuem com o sentido do texto, para que possam dessa maneira posicionar-se em relação a ele de forma crítica e apreciar sua construção estética.

A hipótese estabelecida por esta pesquisa é que as escolhas lexicais revelam determinada intenção de um enunciador e conferem maior expressividade ao texto. Ao analisá-las, o aluno poderá ser capaz de interpretar um texto com base não somente em suas informações explícitas, como também perceber as informações implícitas, podendo refletir sobre como a análise do uso da linguagem e seus recursos expressivos imprimem condições para compreensão do texto.

Os recursos expressivos de uma língua podem revelar muito de seu sistema, assim como o vocabulário de um texto. Contudo, o que se tem percebido é que o estudo do léxico nas escolas brasileiras tem sido realizado de maneira bastante reduzida. É o que observa Antunes (2012). A autora aponta que estudos lexicais têm se resumido ao significado básico das palavras, além disso, na análise textual, 0 aluno não é convocado a argumentar sobre seu entendimento, fazendo a verificação com o apoio dos sentidos expressos por palavras ou expressões dentro de um contexto de enunciação. Portanto, nesse tipo de abordagem restrita, o ensino do léxico não atinge a dimensão da textualidade, uma vez que o léxico não é visto como componente fundamental da construção dos sentidos do texto. Para a autora "falta ver o léxico como elemento da composição do texto, em suas funções de criar e sinalizar a expressão dos sentidos e intenções, os nexos de coesão, as pistas de coerência" (ANTUNES, 2012, p. 24).

Os estudos lexicais têm sido cada vez mais fracionados, ou completamente marginalizados em detrimento dos estudos gramaticais. O lugar assumido pela gramática no ensino da língua não é, entretanto, menos fragmentado. Na concepção do texto, os sentidos pretendidos são estabelecidos pela conjunção das unidades lexicais com as unidades gramaticais, conforme aponta Antunes (2012). Sendo ambas responsáveis pela construção do sentido do texto, e admitindo que o domínio 
da gramática e do léxico se sobrepõe de certa maneira, não há como estabelecer uma dicotomia absoluta. Contudo, tais unidades diferem-se principalmente na amplitude do conjunto em que se inserem, sendo que os elementos gramaticais responsabilizam-se pelo padrão estrutural do texto, enquanto os elementos lexicais preenchem os espaços indicados pelo gramatical.

O ensino da gramática - apesar de ainda ser bastante valorizado no âmbito escolar, principalmente pela dificuldade dos docentes de desvencilharem-se de padrões mais tradicionais de ensino - também tem enfrentado muitos problemas na educação contemporânea. Principalmente pelo fato de se pautar na memorização de regras e nomenclaturas, a gramática passou a ser rechaçada pelos alunos das escolas brasileiras, como observam Kleiman e Sepulveda:

\footnotetext{
Estudos sobre o ensino de gramática em sala de aula mostram que, geralmente, o professor focaliza o ensino de novas nomenclaturas e a definição de novos objetos linguísticos, não levando em conta aspectos da situação do aluno, como faixa etária, interesses e saberes, nem a falta de atividades didáticas que facilitem a aprendizagem (2012, p.13).
}

Porém, a gramática foi detectada como único problema no ensino da língua portuguesa e, de um extremo a outro, o termo "gramática" tornou-se quase que condenável. Estudar a língua enquanto sistema tem seu valor na escola; é por meio desse estudo que o aluno poderá refletir sobre sua própria língua e usá-la com eficiência, segundo intenções e objetivos dentro de uma determinada situação de comunicação. O conhecimento específico do funcionamento das regras não pode deixar de ser abordado pelo professor de língua portuguesa, pois este é o papel que Ihe compete.

Ainda há muito que ser revisto no ensino gramatical, mas aboli-lo não pode ser uma alternativa. Muitos argumentos justificam o ensino da gramática, entre eles:

O conhecimento sobre o funcionamento da própria língua permite o distanciamento que torna possível a conscientização linguística do falante. Sem esse distanciamento e objetivação da língua, baseados em conhecimentos específicos, explícitos, fica impossível ajudar a melhorar seu texto para exprimir aquilo que ele quer, de fato, dizer. $\mathrm{O}$ 
processo de reflexão que consiste na explicitação e sistematização dos conhecimentos sobre a língua está diretamente relacionado a uma melhor compreensão do que se deseja expressar (KLEIMAN e SEPULVEDA, 2012, p.40-41).

O ensino da língua e o ensino da literatura parecem estar dissociados, como se o conhecimento linguístico em nada contribuísse para compreensão do texto. Isso se constata quando o aluno ingressa no Ensino Médio. A prática descontextualizada ao qual foi submetido durante todo seu ensino básico se reflete na impossibilidade de compreender textos que exigem muito mais do que uma leitura horizontal. Por isso, esse tipo de proposta deve ser revisto já no ensino fundamental.

Diante desse quadro, pretende-se com este trabalho, buscar diferentes estratégias que possam contribuir para práticas de ensino mais contextualizadas e eficazes, a fim de colaborar com o desenvolvimento da competência leitora dos alunos do Ensino Fundamental II. O objetivo central da presente pesquisa é verificar, por meio de elaboração e aplicação de sequência didática, se a análise das escolhas lexicais pode auxiliar os alunos do $9^{\circ}$ ano na interpretação textual. Nosso foco é observar as palavras que caracterizam as personagens e o ambiente de um conto. Além disso, pretende-se avaliar a possibilidade de que os alunos desenvolvam maiores habilidades linguísticas por meio da observação do vocabulário de um texto e que consigam estabelecer relações entre a análise gramatical e os sentidos do texto, a fim de que essa observação constitua uma estratégia de leitura capaz de ser aplicada na compreensão de outros textos literários.

Para tal observação, este trabalho se dividirá em cinco partes. Iniciamos com uma parte teórica, objetivando fornecer subsídios para o trabalho do professor em sala de aula. No primeiro capítulo faremos uma breve discussão sobre os conceitos de estilo, buscando explorar também o universo do estilo literário e, em seguida, observar o estilo de Lygia Fagundes Telles, escritora cuja pequena parte da obra foi escolhida para ser levada para sala de aula, por ter uma linguagem de fácil acesso aos estudantes, e escolhas de palavras fundamentais para construção do sentido do texto. 
No segundo capítulo, iniciamos a discussão sobre o léxico e suas funções expressivas. Apresentamos nesse capítulo qual o conceito de léxico que adotamos para a presente pesquisa e buscamos diferenciar as unidades gramaticais e as unidades lexicais, visto que não há como trazer uma proposta de estudo voltado para a educação básica, sem que a sistematização gramatical esteja presente. As questões gramaticais da língua são exploradas nesta pesquisa com o objetivo de ampliar seus conceitos e discutir a insuficiência do ensino que se mostre puramente gramatical. Além disso, nesse capítulo também exploraremos os campos léxicosemânticos, com o objetivo de mostrar a importância da relação semântica das palavras na compreensão textual.

No terceiro capítulo, iremos abordar a função caracterizadora das palavras lexicais do ponto de vista morfológico, estilístico e semântico, com ênfase nos adjetivos, substantivos e verbos. Quando adotamos um ponto de vista mais amplo e amparado por diferentes estudos, percebemos que a função de atribuir uma característica não fica restrita ao adjetivo. $\mathrm{Na}$ análise textual, observar outras classes que exercem essa função é de grande importância para o entendimento do texto.

O capítulo quatro destina-se à aplicação da parte teórica na análise de três contos de Lygia Fagundes Telles: A caçada, Verde lagarto amarelo e Natal na barca. Essa análise pretende fornecer o embasamento teórico necessário para o docente, que fizer a aplicação da sequência didática. Esses contos foram eleitos por apresentarem muitos elementos descritivos que contribuem com o sentido do texto: o estado de espírito oposto de duas mulheres, em Natal na barca; a comparação entre dois irmãos, em Verde lagarto amarelo; e o contraste entre o caçador e o homem, que é representado como caça, em $A$ caçada. Esses contos fazem parte da obra Antes do Baile Verde (publicada em 1970), que reúne dezoito contos de Lygia Fagundes Telles. Por mais simples que pareçam, as narrativas são capazes de surpreender o leitor e avivar seus pensamentos. Sendo o ensino de língua portuguesa cada vez mais centrado na abordagem dos gêneros textuais, discutiremos também como as características do gênero conto podem ser trabalhadas com alunos do $9^{\circ}$ ano.

O capítulo cinco mostra a aplicação de uma sequência didática que será norteada pelos pontos apresentados na fundamentação teórica. Será feita a 
apresentação da proposta, tal como sua implicação para o ensino. Depois, discutiremos a metodologia utilizada, os instrumentos de análise e o resultado obtido. Mostraremos uma proposta de sequência didática para que os alunos possam observar os efeitos expressivos das partes descritivas do texto, assim como a importância das escolhas lexicais, dos efeitos de sentido e dos efeitos estilísticos, de forma que possam analisar e interpretar o texto sob essa perspectiva.

Por último serão tecidos comentários sobre os resultados obtidos, de modo que o estudo possa contribuir com a prática docente. Esperamos que os professores possam usufruir desta pesquisa e aplicar a sequência didática sugerida em sala de aula. 


\section{CAPÍTULO I - QUESTÕES DE ESTILO}

\subsection{Definições de estilo}

A palavra estilo tem origem no latim stilus, empregada para designar "espécie de ponteiro antigamente usado para escrever sobre a camada de cera das tábuas" (CUNHA, 1986, p. 331). Com o tempo, o objeto manejado para escrever passou a significar a própria escrita e depois o que tem de característico na linguagem. Hoje, a palavra serve para designar tudo que apresenta características particulares, desde as coisas banais às altas criações artísticas (MARTINS, 2012).

Encontrar um conceito para estilo é uma tarefa complexa. Várias definições foram dadas a essa palavra com o passar dos anos e, à medida que se transformam as culturas e os padrões sociais, esse conceito se modifica em diferentes períodos e grupos (SPENCER e GREGORY, 1974). Contudo, não nos cabe uma abordagem diacrônica desse conceito, uma vez que uma abordagem histórica da definição de estilo mereça um estudo mais aprofundado. Considerar definições tão diversas só nos afastaria de uma maneira de precisar a palavra.

Apresentar alguns conceitos, entretanto, é necessário para nortear este trabalho. Enkvist (1974) faz um estudo minucioso sobre o estilo e descreve seis abordagens possíveis para sua definição:

1) Estilo como uma concha que envolve o pensamento;

2) Estilo como escolha;

3) Estilo como conjunto de características individuais;

4) Estilo como desvio de uma norma;

5) Estilo como conjunto de características coletivas;

6) Estilo como relações entre entidades linguísticas.

Martins (2012) lembra que um critério não exclui o outro, o que torna mais difícil definir um termo tão inconstante e abstrato. Wartburg e Ullmann (1975) apontam que para uns o estilo consiste na utilização de recursos expressivos da língua, enquanto para outros o estilo está ligado à marca da personalidade do autor. Não há, portanto, um parâmetro consensual para definir o que é estilo. 
Câmara Jr. (1978, p. 13) diz que "o estilo é definição de uma personalidade em termos linguísticos". Bechara (2009), que tomou como base algumas citações de Câmara Jr. para dar noções de estilística em sua Moderna Gramática Portuguesa, define estilo como "conjunto de processos que fazem da língua representativa um meio de exteriorização psíquica e apelo" (BECHARA, 2009, p. 615).

Parece-nos válida a observação de que ambas as definições abordam o uso da língua como recurso para exteriorização do sujeito. Para Spencer e Gregory (1974, p. 75 e 76) "se o estilo em literatura é o produto de um uso particular e, em certa medida único, da língua, está então relacionado com, e dependente de, certas noções da função própria da língua como um todo".

Os autores supracitados no parágrafo anterior buscam uma aproximação da literatura e da linguística. Segundo os autores esse elo se dá pela linguagem:

\footnotetext{
[...] a consequente necessidade de ver a linguagem usada em literatura em termos de linguagem como um todo, significa que parte da discussão que segue deve devotar-se a considerar a contribuição que se pode dar ao estudo do estilo pelas teorias, processos e atitudes da linguística geral e descritiva, cujo interesse particular e o estudo sistemático da totalidade dessa parte da atividade humana chamada linguagem (SPENCER e GREGORY, 1974, p. 76).
}

Pensando na contribuição que a linguística pode trazer ao estudo do estilo, eles definem que quando a linguagem é "o principal foco de atenção no processo dialético - isto é - quando a resposta é principalmente quanto ao uso da própria linguagem - diz-se que o crítico está examinando o estilo do texto" (SPENCER e GREGORY, 1974, p.78).

Apesar de trazer uma aproximação com a linguística, o que será muito válido para o presente estudo, esse conceito não abrange totalmente as questões que gostaríamos de abordar no ensino. Para o estudo em questão, há uma peça chave que deve ser levada em conta na conceituação de estilo, trata-se da expressividade.

Contudo, são de suma importância, como apontam Spencer e Gregory, as contribuições da linguística para a compreensão dos fatores estilísticos. Esse é um fator relevante que nos levou a considerar para este trabalho o conceito de estilo utilizado por Grillo e Vólkova Américo (2013), extraído de um dicionário de termos 
linguísticos, em seu estudo sobre a perspectiva bakhtiniana referente às questões de estilística no ensino da língua:

\begin{abstract}
Um dos diferentes modos de diferenciação da língua; subsistema linguístico com seu léxico peculiar, bem como com composições, usos e construções fraseológicas, distinguindo-se de outros modos por meio dos recursos expressivo-avaliativos de composição de seus elementos e normalmente ligado a determinadas esferas de uso do discurso [...] (AKHMÁNOVA², 2010, apud GRILLO e VÓLKOVA AMÉRICO, 2013, p. 96).
\end{abstract}

Apesar de a definição de estilo ter se baseado em um dicionário de origem russa, tal definição pode ser facilmente aplicada ao ensino brasileiro e, portanto, será utilizada para nortear o presente trabalho. Um dos motivos pelo qual se optou por usar essa definição é o fato de a estilística russa não se restringir ao estilo de autores e correntes literárias, ela aborda a questão de forma mais abrangente, incluindo, por exemplo, a sociolinguística e a análise do discurso (GRILLO e VÓLKOVA AMÉRICO, 2013).

O outro motivo que nos faz adotar tal conceito é o uso do termo "recursos expressivo-avaliativos". Para Wartburg e Ullmann (1974, p. 193) "a expressividade compreende tudo o que ultrapassa o lado objetivo e intelectual da linguagem, a comunicação de fatos ou de ideias”. Bally (1941), pioneiro nos estudos da estilística, diz que expressivo é toda linguagem que pode ser associada a uma emoção. Para esses autores a noção de expressividade está estritamente ligada à escolha e a afetividade, e não há como falar de estilo sem falar em escolhas entre alternativas que podem acrescentar uma carga expressiva ao texto.

\title{
1.20 estilo de Lygia Fagundes Telles
}

Lygia Fagundes Telles é uma das principais escritoras brasileira. Membro da Academia Brasileira de Letras, a escritora paulista tem quatro romances publicados,

\footnotetext{
${ }^{2}$ AKHMÁNOVA, Olga. Slovar lingvistítcheskikh terminov [Dicionário de termos linguísticos]. Moscou: Kníjni Dom Librokom, 2010.
} 
Ciranda de Pedra (1954), Verão no aquário (1963), As Meninas (1973) e As Horas Nuas (1989). A autora ganhou muita notoriedade com seus contos, também publicados em antologias como Antes do Baile Verde (1970), Filhos Pródigos (1978) e A Estrutura da Bolha de Sabão (1991). Tanto no romance, como no conto, Lygia Fagundes Telles recebeu importantes prêmios da literatura, nacionais e internacionais. Foi vencedora do prêmio Jabuti mais de uma vez, recebeu o Primeiro Prêmio no Concurso Internacional de Escritoras na França e ganhou o prêmio Camões em 2005, considerado um dois mais importantes para o ofício de escritor.

O estilo que pretendemos abordar é o estilo da autora como contista. Os contos são parte fundamental da carreira da escritora, como observa Lucas (1990). Ele afirma que a autora tinha vocação para o gênero, portanto não o cultivou apenas como ponto de passagem para o romance, como fizeram outros escritores. $\mathrm{O}$ autor vê os contos de Lygia Fagundes Telles como "unidades polissêmicas", devido ao espaço que sua prosa cede à poesia e à frequência da escolha de temas e das situações que envolvem uma atmosfera de mistérios (LUCAS, 1990). Para Paes (2002), Lygia Fagundes Telles utiliza o poder da metáfora e do símbolo para condensar uma multiplicidade de sentidos. Lamas (2004, p. 89) completa que os contos "se abrem a muitas facetas, apontando simbolismos e caminhos vários."

Os contos de Lygia Fagundes Telles estão marcados pelo simbolismo, pela interioridade humana e pela presença de fortes emoções, como amor, ódio, inveja, sofrimento, solidão, entre outros. Além disso, a presença do fantástico, em alguns de seus contos, fica configurada pelo desenlace em suspenso. A conclusão da narrativa fica sob a responsabilidade do leitor.

Sobre a temática dos contos da autora, Lamas observa:

O conto de Lygia Fagundes Telles percorre sendas várias, desde temas corriqueiros e cotidianos de histórias simples, abarcando também situações complexas e estranhas, até desembocar no sobrenatural e no fantástico, rompendo com limites racionais do humano (2004, p.115).

Para adentrar o gênero fantástico e mergulhar no íntimo da consciência humana, Lygia Fagundes Telles faz uso de uma linguagem nada rebuscada, quase 
coloquial. Seu estilo é sutil, a narrativa é fluida, o que faz com que o efeito final seja ainda mais arrebatador.

Dimas (2009), no posfácio do livro reimpresso Antes do Baile Verde, que ele intitulou Garras de Veludo, bem explica o estilo da escritora, usando uma comparação em que diz "A grande dama não conta: ela murmura, fala baixinho. Aproxima-se do leitor como seus gatos, de que ela gosta tanto (2009, p. 181)". O autor compara o fazer-literário de Lygia Fagundes Telles ao felino: dócil, silencioso, mas com garras retráteis, e quando menos se espera... o arranhão, suficiente para que faça com que se lembre de não mais se aproximar tão confiante! $E$ adverte "Fique esperto! Não confie no ron-ron de Lygia Fagundes Telles (DIMAS, 2009, 182)".

A metáfora utilizada por Dimas (2009) é ótima definidora do estilo de Lygia Fagundes Telles. A linguagem da autora é clara, concisa, tem ritmo. Contudo, como iremos observar na análise dos contos, suas palavras convergem para o efeito de sentido do conto, para o seu simbolismo. Por isso, o estilo de Lygia Fagundes Telles demonstra uma linguagem bem pensada, premeditada, que prepara suas palavras para "dar o bote". Essa observação também é feita no ensaio de Paes (2002, p.75) ao afirmar que "Não se trata, pois, de adornos de linguagem, mas de imagens em abismo ou sínteses miniaturais das linhas de força da ação dramática, cujos significados vêm ampliar com um leque de conotações".

São as escolhas lexicais de Lygia Fagundes Telles que fazem com que sua linguagem, mesmo que substantivada, como Régis (2002) julgou ser, ambiente o conto de maneira que seu texto expresse toda carga emocional a que se propõe. Do ponto de vista lexical, isso ocorre devido ao tratamento que a autora dá à caracterização do ambiente e das personagens, com a criação da cena, a identificação com os atores, tanto nas suas características físicas, quanto nas suas características emocionais; e ao valor semântico das palavras que foram escolhidas justamente para garantir a expressividade do texto.

Muitos dos contos de Lygia Fagundes Telles poderiam figurar nos livros didáticos do $9^{\circ}$ ano do Ensino Fundamental. Além de sua inquestionável qualidade literária, a linguagem simples utilizada pela autora ajudaria os alunos a lerem o texto com facilidade, mas não deixaria de ser uma leitura desafiadora, sem ser impossível. 


\section{CAPÍTULO II - ASPECTOS LEXICAIS}

\subsection{0 conceito de léxico}

No decorrer da apresentação do presente trabalho temo-nos referido diversas vezes a termos como léxico, unidades lexicais, unidades do léxico etc., portanto, cabe aqui uma definição. Não existe um conceito fechado para definir o léxico, a dificuldade de se precisar o termo fez com que Martins (2012) citasse três conceitos, utilizados por Rey-Debove, sendo eles: 1) conjunto de morfemas de uma língua, nesse critério se estabelece que os morfemas são as unidades significativas mínimas, de natureza lexical (classe aberta) e natureza gramatical (classe fechada); 2) conjunto de palavras de uma língua, conceito que tem como imagem o dicionário; 3) conjunto de unidades ou palavras de classe aberta de uma língua.

No entanto, Martins (2012) aponta algumas ressalvas para a adoção dessas definições. No segundo conceito, por exemplo, se faria necessária uma definição do que se considera por palavra. O mesmo acontece com o terceiro conceito, em que seria necessário fazer uma definição precisa de palavra de classe aberta, o que implica também definir as palavras de classe fechada.

Castilho (2012) faz distinção entre o léxico mental, o léxico dos lexicógrafos e o léxico dos gramáticos. O primeiro conceito é o que nos interessa para o presente estudo, a respeito do léxico mental o autor diz:

\footnotetext{
Seu objeto são matrizes cognitivas armazenadas no cérebro, associadas à sua representação linguística. Estuda-se o léxico mental focalizando a associação entre essas matrizes e as formas e os significados lexicais e gramaticais ativados durante a produção e a compreensão da língua (CASTILHO, 2012, p. 109).
}

Antunes (2012) observa que a relação do ser humano com o mundo não se dá diretamente, ela é intermediada pelas coisas e pelas palavras. Segundo a autora, construímos categorias cognitivas das coisas e as palavras expressam tais categorias, dessa forma, a palavra é "a representação linguística dessas categorias cognitivas que construímos e armazenamos" (ANTUNES, 2012, p. 28). 
Genouvrier e Peytard definem o léxico como "conjunto de todas as palavras que, num momento dado, estão à disposição do locutor" (1974, p.279). Nessa definição, o locutor tem à disposição um inventário de palavras. As palavras que ele pode oportunamente empregar constituem seu léxico individual. Uma parte desse léxico pode ser utilizada num ato de fala determinado, conforme as solicitações do momento e, ao conjunto de palavras utilizadas efetivamente nesse ato de fala específico, dá-se o nome de vocabulário. Temos, portanto, o léxico global, que consiste em todo o inventário de itens lexicais disponíveis para o falante; o léxico individual, constituído pelas palavras dos quais o falante tem conhecimento e que podem ser utilizados nas situações que considerar oportunas; e, por fim, o vocabulário, parte do léxico individual que é efetivamente utilizado num contexto de fala específico.

Existem alguns critérios que influenciam esse ato de fala e, portanto, condicionam a escolha das unidades lexicais utilizadas na atividade discursiva. De acordo com Cardoso e lgnez (2012, p.17):

Os falantes de uma língua têm a sua disposição todo o conjunto lexical e dele podem extrair as palavras que desejam para expressar suas ideias, sentimentos etc. Embora todas as palavras pertençam igualmente a esse enorme conjunto, as escolhas são limitadas pelas circunstâncias.

É o que também observa Antunes (2012), que elenca alguns desses fatores determinantes para as escolhas lexicais, entre eles:

1) O que se tem a dizer;

2) Para que se diz;

3) Para quem se diz;

4) Em que gênero o texto irá realizar-se;

5) Que suporte carrega esse gênero;

6) A modalidade de uso da língua (oral ou escrita);

7) O nível de formalidade do texto;

8) O espaço de atuação (cena ou contexto).

São esses os fatores que fazem com que o enunciador escolha entre um item lexical ou outro na realização do discurso, além disso, o efeito expressivo que se 
quer dar ao texto também irá contribuir para tais escolhas, sobretudo no texto literário. É como se considerássemos mais um item entre os primeiros que foram listados: o que se diz, para que se diz, para quem se diz e como se diz. Esse último considera a intenção do autor e a impressão que ele quer causar no seu leitor. Conforme Antunes:

\footnotetext{
Pensar 'nos efeitos decorrentes da escolha das palavras' é reconhecer que, em um texto, uma palavra expressa mais que um sentido; ela serve também à expressão de uma intenção, de um propósito (às vezes, mais de um!), em função do que determinadas palavras (e não outras) são particularmente escolhidas (2012, p.43).
}

De acordo com essas observações, o conceito de léxico adotado para a presente pesquisa é bastante amplo, trata-se de um repertório de palavras rico e dinâmico, que se encontra à disposição dos falantes de uma língua para serem utilizados num dado momento de comunicação, cuja organização enunciativa é condicionada por circunstâncias discursivas.

\subsection{Unidades lexicais e unidades gramaticais}

A distinção entre as unidades do léxico e as unidades da gramática tem sido adotada por muitos autores que têm se debruçado sobre o estudo do léxico e da estilística léxica. Tal distinção também é importante para a presente pesquisa, uma vez que nos dispomos a elaborar uma proposta didática que vise enfatizar os elementos lexicais, sem, contudo, desprezar a sistematização gramatical.

Antunes (2012), por exemplo, admite que tal distinção é uma opção metodológica de estudo e que as unidades do léxico e os elementos da gramática, em conjunção, contribuem à construção dos sentidos do texto. Contudo, é necessário precisar esses conceitos, para que possamos deixar claro com quais unidades queremos trabalhar neste estudo.

Martins (2012) considera a existência de duas espécies de palavras: as palavras gramaticais, cuja significação só pode ser apreendida no contexto linguístico, e as palavras lexicais, que têm significação extralinguística, por terem capacidade de, mesmo que isoladas, despertarem uma representação na mente 
humana. São consideradas palavras lexicais os substantivos, os adjetivos, os advérbios e os verbos, excluindo-se os verbos de ligação e os auxiliares.

Encontramos também em Lapa (1998) divisão semelhante entre palavras, que corrobora essa ideia. Para ele, existem as palavras reais, que carregam o sentido da frase, constituídas pelo substantivo, adjetivo, verbo; e os instrumentos gramaticais, que estabelecem ligação entre idéias, englobando os artigos, as preposições, as conjunções e por vezes também os advérbios, numerais e pronomes. Porém, é importante ressaltar que se trata de uma divisão teórica, pois dentro de um enunciado as palavras lexicais também necessitam de um componente gramatical.

Antunes diz que as unidades do léxico são:

[...] as unidades cujo significado remete às coisas, aos fenômenos do mundo da experiência, do mundo extralinguístico, a seus modos de existir, a suas propriedades e manifestações; estabelecem, portanto, a vinculação entre a língua e a experiência; têm índices de frequência variáveis, pois dependem do gênero e do tema em desenvolvimento (2012, p. 32).

Já os elementos da gramática são definidos pela autora como:

[...] unidades cujo significado remete ao interior do próprio sistema linguístico, constituindo-se em índices da função e da relação que as formas constituintes de um enunciado exprimem; são de alta frequência e costumam ocorrer em todo tipo de gênero de texto (2012, p. 32).

Todo item lexical carrega em si a responsabilidade do significado da frase, possui significado extralinguístico e seu uso está condicionado a situações de comunicação específicas. Já as unidades gramaticais estão mais ligadas às construções estruturais do texto. Isso também foi observado por Genouvrier e Peytard (1974), que elencam duas principais diferenças entre as unidades do léxico e as unidades da gramática.

$\mathrm{Na}$ primeira delas, os autores afirmam que tudo o que pode nomear a experiência vivida por nós é lexical, enquanto aquilo que se limita a expressar uma modalidade do elemento designado é gramatical. Assim, em o carro, a palavra carro 
designa um elemento extralinguístico e, portanto, carrega o sentido da frase, enquanto que o artigo limita-se a determiná-lo. O segundo fator considerado é a amplitude dos conjuntos lexicais e gramaticais. Os elementos lexicais, embora com índices de frequência variáveis, como observado por Antunes (2012), pertencem a conjuntos bastante amplos, ao passo que os elementos gramaticais pertencem a conjuntos limitados.

A partir de um padrão estrutural, poder-se-ia preencher as lacunas com inúmeros substantivos e verbos, porém a quantidade de artigos e de preposições é bem mais limitada. Com isso "vemos assim que o gramatical representa, num enunciado, o padrão que o estrutura, ao passo que o lexical, fornece as palavras suscetíveis de inserção nos espaços indicados pelo gramatical" (GENOUVRIER e PEYTARD, 1974, p.297).

Portanto, adotamos como foco na presente pesquisa as unidades lexicais, o que significa que vamos nos concentrar nos adjetivos, nos substantivos e nos verbos em nossa análise, sem o propósito de explorar unidades gramaticais como as conjunções, os pronomes, os artigos, as preposições etc. A adoção de tal conceito não significa que a sistematização da gramática deixará de ser abordada quando apresentarmos a proposta didática, apenas demonstra que determinadas palavras apresentam mais possibilidades na exploração dos sentidos do texto e delimita os itens que serão enfatizados em nossa análise.

\subsection{0 léxico e suas funções expressivas}

Existem certos fatores determinantes para certas escolhas lexicais e tais escolhas podem não somente determinar uma posição, como também uma intenção, por vezes com valores expressivos, o que pode refletir determinado estilo. Faz-se necessário, para explorar as funções expressivas do léxico, adentrar o campo da estilística.

Uma vez que a estilística volta-se para o estudo da linguagem e seu estilo, e que vimos que o conceito de estilo é bastante complicado de se delimitar, podemos observar que o escopo da estilística é bastante amplo. 
A estilística interessa-se pela força expressiva das palavras, pelos conteúdos emotivos da linguagem, pelos desvios da norma, pelos neologismos, pela sinonímia, pelas metáforas, pelas escolhas realizadas no código linguístico e muito mais.

Em seu estudo detalhado sobre a estilística, Martins (2012) discute sobre as vertentes da disciplina dividindo-as em estilística do som, estilística da frase, estilística da enunciação e estilística da palavra. A esta última é que pretendemos nos ater neste trabalho.

Segundo o trabalho da autora, o estudo da estilística da palavra, ou estilística léxica, envolve "os aspetos expressivos das palavras ligados aos seus componentes semânticos e morfológicos, os quais, entretanto, não podem ser completamente separados dos aspectos sintáticos e contextuais" (MARTINS, 2012, p. 97).

A estilística léxica importa-se com a tonalidade emotiva das palavras. Martins (2012) divide as palavras com tonalidade emotiva em grupos: palavras com significado afetivo, palavras que exprimem julgamento, palavras que exprimem avaliação, palavras com sentido avaliativo relacionado a prefixos e sufixos e palavras evocativas. É com base no estudo dessa autora, e de outros autores que complementam esse estudo, que procuramos explicar cada um desses grupos:

- Palavras com significado afetivo: são aquelas que exprimem sentimentos, emoções, um estado psíquico. Destacam-se nesse grupo os adjetivos e os substantivos abstratos. Para Lapa (1998), as palavras distinguem-se por seu valor sentimental ou intelectual. Apesar de aceitar a dificuldade dessa distinção, o autor considera que para se escrever bem é necessário que seja feita uma reflexão na escolha das palavras, pois umas despertarão mais nossa inteligência e outras nossa sensibilidade. Sendo assim, às palavras de significado afetivo é atribuído maior valor sentimental. Sobre o significado afetivo das palavras, pode-se dizer ainda que

implica a compreensão de que os sentidos das palavras podem assumir, para além de seu valor descritivo, um componente afetivo, derivado das determinações culturais de cada grupo ou das particularidades do enunciador em certo evento comunicativo; assim é que a palavra 'indelicado' soa menos ofensiva que a palavra 'grosseiro' ou 'estúpido'; evidentemente, tais significados afetivos decorrem da forma como as pessoas, em seu convívio social, 
constroem e sedimentam a percepção que têm das coisas; são, portanto, deslizes de sentido que se vão registrando em sintonia com as particularidades de visão de cada grupo social (ANTUNES, 2012, p.43-44).

- Palavras que exprimem julgamento: destacam-se nessa classe os adjetivos que atribuem qualidades marcadas por uma oposição (positivo/negativo, bom/mau). Como na frase "Ele usa uma camiseta barata". Em certos contextos, o adjetivo barata pode estar associado à má qualidade da roupa, aos padrões de moda, ou falta de poder aquisitivo. O contrário poderia ser observado em "Ele está usando uma camiseta cara".

- Palavras que exprimem avaliação: quando o elemento de avaliação está anexado à palavra. Por exemplo, a palavra barraco, no sentido de moradia, que pode ser mentalmente associada à pobreza, miséria, periferia etc. O uso dos prefixos e sufixos também pode carregar os lexemas de elementos avaliativos. Eles podem adquirir valores pejorativos (livreco), ou valores sentimentais como ternura (professorinha) e amor (mãezinha). Para Lapa (1998), os sufixos interessam muito mais a estilística, pois neles que a descarga das paixões se dá com maior energia, enquanto que os prefixos estão quase sempre ligados a uma ideia intelectual.

- Palavras evocativas: são palavras que nos remetem a uma determinada época, ambiente, meio social etc. São de grande interesse da estilística e fazem parte dessa classe os estrangeirismos, os neologismos, os arcaísmos, as gírias, os indigenismos e os regionalismos.

As escolhas linguísticas são de fundamental importância na expressão verbal, sendo que uma palavra pode assumir maior expressividade do que a outra, apesar de ter o mesmo significado, muda-se o efeito de sentido. Conforme afirma Monteiro (2009, p. 99): “A escolha de um elemento em vez de inúmeros outros disponíveis no código é uma questão de âmbito estilístico. Cada unidade lexical se liga a uma série virtual que permite múltiplas variações".

Para fins de exemplificação, pode-se construir uma frase com a seguinte seleção: O homem retornou a sua casa. O enunciado encontra-se dentro dos padrões da língua culta, contudo, se a intenção é a de dar maior expressividade à frase pode-se dizer: $O$ homem retornou ao seu lar. Ao substituirmos a palavra casa 
pela palavra lar, demos maior expressividade ao local de regresso do homem que agora pode ser associado a aconchego, descanso, família etc.

Portanto, é muito importante que se observem as escolhas lexicais, tanto na leitura do texto quanto em sua produção, pois estas revelam, além da intencionalidade do autor, quais recursos expressivos o autor utilizou e se esses recursos atingem o efeito de sentido esperado.

\subsection{Campos léxico-semânticos}

Quando lemos ou escrevemos, nosso cérebro relaciona os itens lexicais selecionados a uma outra gama de palavras. Seja pelo seu significado, seja pelo seu aspecto formal, somos levados a fazer associações que nos remetem a diversos lexemas diferentes. De acordo com Ullmann:

[...] todas as palavras estão cercadas por uma rede de associações que as ligam com outros termos. Algumas dessas associações baseiam-se em ligações entre os sentidos, outras são puramente formais, enquanto que outras, finalmente envolvem ao mesmo tempo a forma e o significado (1964, p. 498).

Saussure, considerado pai da linguística moderna, havia analisado que um termo converge em uma "constelação" com um número tão vasto de palavras cuja soma é indefinida. Bally introduziu o conceito de campo associativo, definindo-o como halo que circunda o signo cujas franjas se confundem com o ambiente. De acordo com Ullmann:

[...] o campo associativo de uma palavra é formado por uma intrincada rede de associações, baseadas algumas na semelhança, outras na contiguidade, surgindo umas entre sentidos, outras entre nomes, outras ainda entre ambos. O campo é por definição aberto, e algumas das associações estão condenadas a ser subjetivas, embora as mais centrais sejam em larga medida as mesmas para a maioria dos locutores (1964, p. 500 - 501). 
Depois, com outros teóricos, além dos campos associativos, passou-se a observar outras possibilidades de associação. Os estudiosos expandiram os conceitos da teoria dos campos e diferentes nomenclaturas foram sendo agregadas à teoria, como campos lexicais, campos semânticos, campos conceituais etc.

Para fins didáticos, citamos os conceitos elaborados por Henriques (2011), que define campo associativo como aquele que permite qualquer associação coerente, semântica ou não, para reunir palavras; campo conceitual como contingente de palavras agrupadas por fator ideológico, por meio de uma rede de interligações e associações de sentido; por fim, o campo semântico, que agrupa linguisticamente um contingente de palavras, também por meio de associações e interligações de sentido.

O exemplo prático trazido por Henriques (2011) na aplicação das definições de cada um dos campos sugere uma constelação com a palavra escravidão. $O$ autor sugere que o campo conceitual contenha palavras que se associassem a ideia de restrição de liberdade, vínculo que restringe a liberdade ou algo difícil de livrar-se. Portanto poderiam integrar esse campo palavras como cativeiro, sacerdócio ou submissão. Como exemplo de campo semântico poder-se-ia elencar palavras da mesma família etimológica, ou com a mesma formação sufixal, é o caso das palavras escravidão, escravizar, escravatura (semelhança no radical) e escravidão, aptidão, vermelhidão (semelhança no sufixo formador de substantivo abstrato).

Em seus estudos o autor considerou uma vasta possibilidade para os campos associativos, como a associação semântica (cativeiro, clausura); identidade sonora na terminação (rapagão, combustão); identidade de família etimológica (escravizar, escravatura), entre outros. Entretanto, nosso objetivo é abordar apenas a associação semântica, tendo em vista que objetivamos que a construção de um campo lexical contribua para o entendimento de um texto, portanto, é necessário observar os sentidos das palavras. Dessa forma, adotamos essa perspectiva, e denominamos campo léxico-semântico.

Por conta da abrangência do campo associativo, muitos autores não fazem essa subdivisão, adotando esse termo de forma genérica, isso é uma prática comum. Já Henriques (2011) afirma que os campos semânticos privilegiam a estrutura lexical como um todo, enquanto os campos conceituais constituem esquemas representacionais da sociedade. 
O autor supracitado afirma que as associações se constroem a partir do raciocínio humano, daí a importância dessa teoria para a presente pesquisa. Segundo Ullmann:

a teoria dos campos fornece um método valioso para abordar um problema difícil, mas de crucial importância: a influência da linguagem no pensamento. Um campo semântico não reflete apenas as ideias, os valores e as perspectivas da sociedade contemporânea; cristalizaas e perpetua-as também; transmite às gerações vindouras uma análise já elaborada da experiência através da qual será visto o mundo, até que a análise se torne tão palpavelmente inadequada e antiquada que todo o campo tenha que ser refeito (1964, p. 523).

Ullmann (1964) defende a ideia de que os campos semânticos têm um papel na organização das experiências humanas, percebe-se que o conceito que ele aborda não é o mesmo descrito por Henriques (2011). O que nos importa aqui é observar que tais campos podem refletir a influência que a linguagem tem no pensamento, dessa forma, a investigação dos campos léxico-semânticos de um texto poderão auxiliar-nos na elaboração de atividades que nos permitirá analisar como os alunos organizam seu pensamento diante do vocabulário de um texto e como a estrutura desse campo como um todo poderá ajudar na interpretação desse texto. 


\section{CAPÍTULO III - PALAVRAS COM FUNÇÃO CARACTERIZADORA}

\subsection{A abordagem gramatical}

Já mencionamos que vamos trabalhar com as unidades lexicais nesta pesquisa, e que isso implica nos concentrar na classe dos adjetivos, dos substantivos e dos verbos. Neste item, pretendemos explorar como a gramática aborda essas palavras do ponto de vista morfológico e mostrar que a abordagem gramatical não é suficiente para analisar os elementos descritivos de um texto.

Os gramáticos latinos não faziam distinção entre adjetivo e substantivo, ambos eram reunidos na classe dos nomes. De acordo com Castilho (2012), a gramática latina reunia, tanto substantivo como adjetivo na classe dos nomes, sob especificação de nomen substantium e nomen adjectium. A razão disso era, sobretudo, a forma como os substantivos e os adjetivos eram afetados pela mesma categoria do gênero e do número.

No século XVIII a gramática românica começa a tratar substantivo e adjetivo separadamente, portanto Castilho (2012) descreve alguns argumentos que diferenciam essas duas palavras, a fim de demonstrar suas diferenças morfológicas. Alguns deles como a flexão ${ }^{3}$ admitida pelos adjetivos por meio do acréscimo de determinados sufixos, como em branquíssimo. Para o autor, quando um sufixo superlativo se aplica ao substantivo, ocorre sua recategorização, ou seja, a mudança de classe gramatical. Dessa forma, Castilho (2012) mostra por meio do exemplo: o governador é candidatíssimo a presidência da República, que o substantivo candidato, agregado ao sufixo, assume função adjetiva na sentença. Outro argumento apresentado é o fato de os adjetivos aceitarem os sufixos -vel, como em amável e provável, assim como aceitar o sufixo -mente, que os transformam em advérbios, como em facilmente. O último ponto de distinção morfológica apontado é

\footnotetext{
${ }^{3}$ Referimo-nos aqui como flexão do adjetivo por assim ser tratado na gramática em análise. Contudo, acreditamos, assim como muito estudos em voga há bastante tempo inclusive, não se tratar de uma flexão, já que confere à palavra valores expressivos. Trata-se de um sufixo derivacional, como observado por Mattoso Câmara Jr. (1970) por não ter obrigatoriedade na sistematização da língua e por seu uso ficar condicionado a vontade do falante.
} 
a derivação de quantificação aceita pelo adjetivo, expressa por -oso e -al. Assim, palavras como estudioso e sensacional inserem-se na classe dos adjetivos, de acordo com a visão gramatical, enquanto mesa e cadeira, por exemplo, só podem fazer parte da classe dos substantivos, por não aceitarem esse tipo de derivação em seu uso comum na língua, como mesal e cadeiral, ou mesosa e cadeirosa.

Para Castilho (2012), procurar uma distinção taxativa para as classes de palavras é algo bastante complicado, pois muitas relações podem ser reconhecidas em membros de categorias diferentes. É o caso da adjetivação, assegurada por alguns processos gramaticais que se dão conforme o autor ilustra:

1. Através da intensificação, um substantivo torna-se adjetivo: Fulano é muito homem.

2. Através da sufixação gramatical, um verbo torna-se adjetivo: é o caso dos particípios passados. Os particípios sempre foram considerados como verbos não prototípicos, meio verbos, meio adjetivos, e disso decorre sua denominação.

3. Substantivos se recategorizam como adjetivos. Assim, vermelho deriva do substantivo diminutivo vermiculus; louro deriva do substantivo laurus (CASTILHO, 2012, p. 516 - grifos do autor).

Compreender o processo de adjetivação permite que percebamos conscientemente que muitas palavras podem atuar como elementos caracterizadores, sem a exata necessidade de encaixá-las nessa ou naquela categoria.

Não há dúvidas que o adjetivo tem um papel fundamental na descrição. Na gramática de Cunha e Cintra (2013) esse é, de fato, o papel atribuído ao adjetivo. Os autores conceituam que o adjetivo é essencialmente um modificador do substantivo; caracteriza seres, objetos ou noções nomeadas pelo substantivo, atribuindo-lhes qualidade ou defeito, modo de ser, aspecto ou aparência, estado; pode também estabelecer relações como o substantivo, de tempo, espaço, matéria, finalidade, procedência, entre outros.

Bechara (2009, p.142) define o adjetivo como "classe de lexema que se caracteriza por constituir a delimitação, isto é, por caracterizar as possibilidades designativas do substantivo, orientando delimitativamente a referência a uma parte ou a um aspecto do denotado". 
Cunha e Cintra (2013) também abordam que algumas palavras pertencentes a outras classes gramaticais podem servir para caracterizar o substantivo, portanto, valem semanticamente como adjetivos. Os autores analisam que alguns substantivos podem funcionar como instrumentos de caracterização quando: o substantivo principal está associado a outro substantivo em forma de aposto (o tio Joaquim); quando o substantivo é empregado em locuções, precedido de preposição (barco a vela $=$ veleiro $)^{4}$; quando o adjetivo é substituído por um substantivo abstrato (Sofreu o destino cruel / Sofreu a crueldade do destino).

Nas gramáticas consultadas, algumas formas verbais também são vistas com função de nomes. Esse tratamento é dado ao que a gramática intitula como formas nominais do verbo. Para Bechara (2009), a função adjetiva é atribuída aos verbos do particípio e do gerúndio, como nos exemplos citados pelo autor: homem sabido (particípio) e água fervendo (gerúndio). O mesmo é observado por Castilho (2012). Ambos consideram que, quando desempenham função nominal, o infinitivo tem a função de substantivo, o particípio de adjetivo e o gerúndio de adjetivo ou advérbio.

Já Cunha e Cintra (2013) enfatizam a função caracterizadora ao particípio, quando este exprime o estado sem estabelecer relação temporal, confundindo-se com o adjetivo. Contudo também abordam que a forma infinitiva do verbo pode ter sentido narrativo ou descritivo, em frases nominais, como em "horas depois, e a mulher a gritar", o uso do infinitivo nessa frase descreve a ação da mulher, por isso não deixa de atribuir-Ihe uma característica.

Acreditamos que a possibilidade de um verbo atribuir uma característica é um processo que está muito mais ligado ao contexto do que a sua forma verbal. Podemos, por exemplo, perceber o uso do gerúndio com função adjetiva na frase $O$ cantor, suando, entrou no palco, em comparação a $O$ cantor suava quando entrou no palco (= cantor suado). $O$ mesmo ocorre com o uso do particípio em $A$ garota tinha suspirado a manhã toda, em que outras formas verbais podem também $A$ garota suspirou a manhã toda. A própria carga semântica do verbo suspirar já imprime uma característica à atitude da garota, em um contexto específico pode significar um lamento, ou mesmo um desejo.

\footnotetext{
${ }^{4}$ Bechara (2009) também se refere a essa forma de caracterização, a qual ele se refere como locução adjetiva.
} 
Não encontramos nas gramáticas citadas nenhuma referência semântica ao uso dos verbos como elementos caracterizadores, ou sobre seu efeito estilístico. Por isso defendemos que tais noções precisam ser ampliadas pela estilística e pela semântica.

\subsection{Ampliando conceitos}

É na área da Estilística que encontramos uma visão ampla dos itens lexicais que podem exercer uma função caracterizadora, nessa área são abordadas outras classes de palavras que também podem cumprir essa função, como os substantivos, os adjetivos e os verbos.

Nos estudos de Lapa (1998) encontramos uma análise dos efeitos estilísticos vistos sobre o prisma das classes de palavras. Para ele, o adjetivo é elemento fundamental na caracterização dos seres, portanto "tudo quanto sirva para caracterizar, jeito de entonação, palavra ou frase, vale como adjetivo" (LAPA, 1998, p.119). Ele observa algumas possibilidades de palavras e locuções que assumem função adjetival na língua portuguesa, são elas: entonação, substantivos expressivos que trazem consigo um elemento caracterizador, substantivos que caracterizam outros substantivos (caso frequente com o uso do nome das cores), substantivos precedidos de preposição, orações com uso do pronome relativo, formas verbais com função de adjetivos. Lembrando que, para Lapa (1998), os adjetivos são palavras reais, portanto, carregam em si a responsabilidade do sentido da frase.

$O$ autor também observa os pontos de contato entre o substantivo e 0 adjetivo, e conclui que as duas classes pouco se diferenciam. Segundo o autor:

[...] o substantivo pouco se difere do adjetivo; no fundo, são dois aspectos duma mesma realidade linguística. A própria origem do nome tem mais de adjetivo do que substantivo. Com efeito, ao princípio, todos os seres foram designados por uma qualidade fundamental que os caracteriza (LAPA, 1998, p. 110 -111). 
Os processos de caracterização com o emprego dos substantivos são bastante frequentes, Martins (2012) também observa como forte recurso estilístico o uso dos substantivos abstratos no lugar dos adjetivos, para ela:

Através do adjetivo o falante caracteriza emocionalmente o ser de que fala; através do substantivo abstrato destaca o sentimento, a qualidade, o estado, apresentando-os com mais realce, menos presos ao ser (MARTINS, 2012, p. 106 - 107).

Como já observamos, ela destaca os adjetivos como palavras que exprimem um significado afetivo, um julgamento, um elemento de avaliação. Cardoso (2013, p.17) observa que "mesmo que o texto seja puramente referencial, objetivo, ele carrega consigo um aspecto intencional, seja o desejo de impressionar o destinatário, seja um desejo de marcar uma posição". Daí a importância de se observar os elementos selecionados para fazer a caracterização, pois esses elementos podem revelar uma suposta intencionalidade do autor, uma posição do enunciador, uma opinião emitida, entre outros. Como resume Monteiro:

a interpretação dos enunciados é algo extremamente complexo, pois o processo de escolha e combinação dos elementos pode ser condicionado por fatores extralinguísticos, entre os quais o conhecimento de mundo ou as experiências e vivências individuais (2009, p. 150).

Lapa (1998) observou ainda a existência de adjetivos de valor intelectual e adjetivos de valor afetivo. Ele aponta que certas palavras têm um significado objetivo, de representação puramente intelectual, outras são acompanhadas de sentimentos.

Bally (1941) exemplifica como um adjetivo pode assumir um caráter subjetivo e afetivo, fazendo uso do vocábulo dramático ele explica:

Assim o adjetivo "dramático", em "a arte dramática", acrescenta ao substantivo um caráter específico, sem trazer emotividade ou subjetivismo; mas em "um incidente dramático", o mesmo adjetivo 
expressa um valor subjetivo e descarrega uma corrente de afetividade, mesmo que seja fraca ${ }^{5}$ (1941, p. 25 - Tradução nossa).

Conforme apontado por Lapa (1998), a afetividade atribuída ao adjetivo dependerá de um contexto e do substantivo que acompanhará o adjetivo.

Outra característica apontada pela Estilística é a posição do adjetivo na frase. Em geral, os adjetivos pospostos têm como objetivo atribuir ao substantivo característica que se exime de carga conotativa, ou seja, o adjetivo que precede o substantivo estaria empregado no seu sentido verdadeiro, enquanto o adjetivo anteposto parece impregnar-se de sentimentos, adquirindo caráter mais afetivo. É o que podemos observar na crônica Onde já se viu?", de Tatiana Belinky: "Tanta criança rica não sabe o que perde, não lendo, e este menino pobre - que certamente não era um pobre menino - sabe o valor que tem essa maravilha que se chama livro!".

A autora deixa claro que a expressão "menino pobre" se distingue da expressão "pobre menino". A alternância da posição do adjetivo marcou diferentes significados, na primeira frase é feita uma referência à condição financeira do menino, enquanto na segunda o intuito é dizer que o menino não era desprovido de inteligência, tolo.

Portanto, a posição do adjetivo no texto altera seu sentido, confere-lhe mais ou menos expressividade, por isso deve ser levada em conta na análise textual.

Assim como Lapa (1998) desenvolveu as características do adjetivo em seus estudos estilísticos, na Semântica encontramos intenção semelhante na pesquisa de Catherine Kerbrat-Orecchioni.

Kerbrat-Orecchioni (1980) dedicou-se ao estudo da subjetividade da linguagem. Nesse estudo, desenvolveu um capítulo sobre o adjetivo, no qual propôs que algumas unidades lexicais são mais objetivas, enquanto outras unidades são mais subjetivas.

\footnotetext{
${ }^{5}$ Texto original: Así el adjetivo "dramático", en "el arte dramático", añade al sustantivo um caráter específico, sin traza de emotividad ni de subjetivismo; pero en "un incidente dramático" el mismo adjetivo expresa um valor subjetivo y descarga uma corriente de afectividad, por débil que sea.

${ }^{6}$ BELINKY, Tatiana. Onde já se viu? São Paulo: Ática: 2004.
} 
Embora admita a linha tênue que se estabelece nessas divisões, a autora faz a distinção da categoria dos adjetivos, dividindo-os em objetivos e subjetivos. Estes últimos também apresentam uma subdivisão, conforme o esquema apresentado pela própria autora, que ilustramos a seguir.

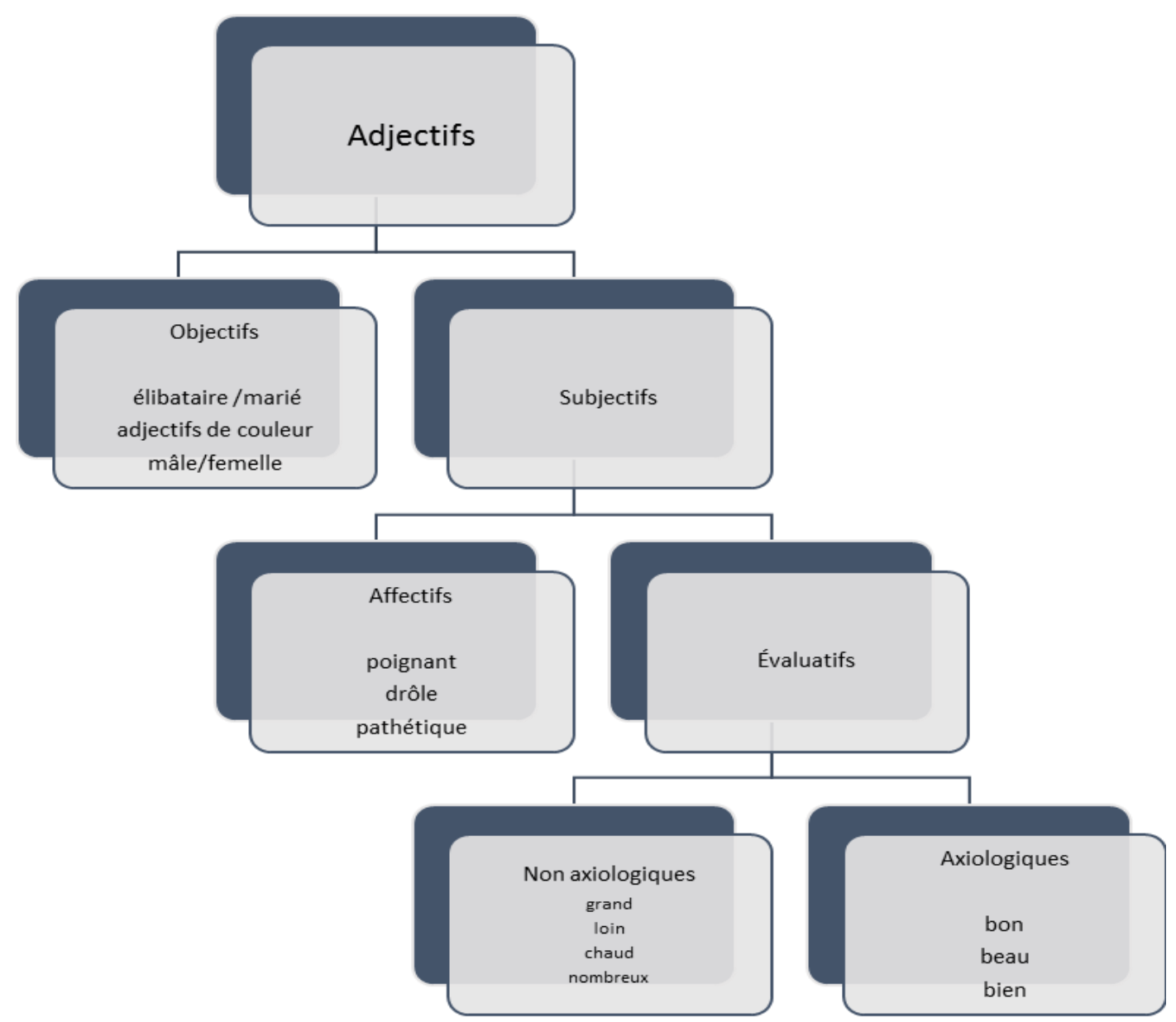

Esquema 01: Categoria dos adjetivos de acordo com Kerbrat-Orecchioni (1980, p.84) ${ }^{7}$.

Os adjetivos subjetivos estão no nível interpretativo da linguagem, são apreendidos pelo contexto e sua principal característica é atribuir um julgamento de valor do enunciador.

Para Kerbrat-Orecchioni (1980), os adjetivos afetivos podem tanto designar uma propriedade do objeto que está sendo determinado, como também indicar uma reação emocional do falante diante do objeto. A autora demonstra como o uso dos

\footnotetext{
7 Termos utilizados no esquema: Adjetivos; Objetivos (solteiro/casado, adjetivos de cores, macho/fêmea); Subjetivos; Afetivos (pungente, engraçado, patético); Avaliativos; Não Axiológicos (grande, longe; quente; numeroso); Axiológicos (bom, bonito, bem). Tradução nossa.
} 
adjetivos do segundo caso, em que o falante expressa reação emocional, poderia ser prejudicial em textos judiciários, exemplificando com frases como "pobre vítima" ou "assassino cruel". Ao se afirmar que certos textos precisam ser dotados de objetividade e deles devem ser excluídos qualquer traço de emoção ou sentimento, admite-se que certos adjetivos possuem uma carga maior de afetividade.

Além do contexto, significantes prosódicos, tipográficos ou sintáticos (caso da anteposição do adjetivo) também contribuem para atribuir valor afetivo ao adjetivo. Ullmann (1964) também abordou a anteposição do adjetivo como artifício emotivo, o que ele chamou de artifício sintático. Para ele, certas línguas permitem que as palavras possam ser livremente movidas com intuito de realces e efeitos emotivos, além disso, pode-se também obter efeitos sutilmente irônicos.

Ainda segundo Ullmann (1964, p. 285) "O valor emotivo do adjetivo em posição anterior pode ser reforçado pela repetição [...] ou pelo uso do mesmo adjetivo em dois lugares opostos dentro da mesma oração". Percebe-se que esses estudos semânticos estão bastante próximos dos estudos estilísticos.

Prosseguindo com a classificação proposta por Kerbrat-Orecchioni, temos os adjetivos avaliativos não-axiológicos. Pertencem a essa classe os adjetivos que independem de um juízo de valor ou engajamento afetivo do locutor, os adjetivos de avaliação não axiológica pressupõem uma avaliação qualitativa ou quantitativa ligada a duas normas: qualidade interna ao objeto; e avaliação específica do enunciador. Nas palavras da autora "o uso de um adjetivo avaliativo é relativo à ideia que o locutor tem da norma de avaliação aplicado a categoria de um dado objeto" 8 (KERBRAT-ORECCHIONI, 1980, p. 86 - tradução nossa). Entretanto, a autora ressalva que essa categoria faz uso estrito da definição lexical, inserido em um contexto as palavras podem tornar-se mais afetivas ou axiológicas.

Os adjetivos de natureza axiológica também dependem da observação de duas normas: interna a classe do objeto; interna ao sujeito da enunciação e relativa ao seu sistema de avaliação. Os adjetivos de natureza axiológica, portanto, determinam um julgamento de valor, positivo ou negativo. De acordo com KerbratOrecchioni, são duplamente subjetivos, pois manifestam uma posição a favor ou

\footnotetext{
${ }^{8}$ Texto original: l'usage d'um adjectif évaluatif est relatif à l'idée que le locuteur se fait de la norme d'évaluation pour une catégorie d'objets donnée.
} 
contra um objeto determinado e refletem uma competência ideológica particular do enunciador.

Ullmann (1964) também analisou palavras cuja função principal era a de exprimir um elemento de avaliação ou comentário emotivo. Segundo ele, nessas palavras o elemento emotivo é parte integrante de seu significado central. É o caso de adjetivos como bom, estúpido, divertido etc. Além dos adjetivos, ele observa que algumas palavras contêm um elemento de avaliação sobreposto ao significado principal, exemplificando com a palavra rabiscar, que combina a ideia de escrever a maneira desleixada de praticar essa ação, indicando a falta de cuidado.

Já havíamos discutido, no segundo capítulo, a respeito das palavras que exprimem uma avaliação. O interessante de se observar no exemplo fornecido por Ullmann é que ele não apenas considera o substantivo rabisco, como também o verbo rabiscar. Isso mostra que a função caracterizadora de uma palavra está ligada a carga semântica que lhe é atribuída.

Por isso, quando mencionamos a abordagem gramatical, dissemos que os verbos têm importante papel na descrição, não somente por apresentar formas nominais, mas, como também já discutimos no presente trabalho, por apresentaremse como uma palavra real e serem nucleares na organização de frases verbais.

Entretanto, os referenciais teóricos de que dispomos atualmente, deixam de abordar com profundidade essa característica dos verbos. Tanto na gramática, quanto na estilística, o foco das formas verbais como caracterizadoras está nas formas nominais do verbo. Essas áreas concentram-se mais nos verbos no gerúndio, no particípio e, algumas vezes, no infinitivo, para fornecer exemplos de estruturas verbais que podem exercer função caracterizadora.

A leitura dos textos literários que nos dispomos a analisar no presente estudo mostra que não podemos deixar de levar em conta a existência da função caracterizadora dos verbos. Isso justifica a observação dessas três classes gramaticais, mesmo que os verbos caracterizadores apareçam em menor frequência do que os substantivos ou os adjetivos. Um exemplo da importância de se levar em conta outras formas verbais que podem exercer caracterização pode ser verificada nos seguintes fragmentos do conto Verde Lagarto Amarelo:

- Ao contrário, engordei, não está vendo? (TELLES, 2009, p. 22) 
Mas, filho, comendo de novo?! Quer engordar mais ainda? Hum?... (TELLES, 2009, p.28)

O verbo engordar destacado nos trechos acima mostram uma característica da personagem Rodolfo. Ele era gordo, tipo físico que é enfatizado no conto para mostrar o sentimento de inferioridade que ele tem. Sem fazer uso de um adjetivo, percebemos essa característica sendo ressaltada pelo verbo engordar, principalmente na fala da mãe de Rodolfo, que o repreende por estar comendo. Ela destaca que engordará ainda mais, ou seja, ele já é gordo, e a mãe teme que esse vício possa agravar-se, tornando-o ainda mais desagradável aos olhos maternos. Trata-se, portanto, da identidade física de uma personagem sendo descrita pelo uso de um verbo.

Outro exemplo de uma personagem sendo descrita por meio do uso de verbo pode também ser observado no conto $A$ caçada. $O$ verbo tremer é utilizado no pretérito imperfeito do indicativo, caracterizando a personagem:

O homem acendeu um cigarro. Sua mão tremia. (TELLES, 2009, p. 68)

Nessa passagem, o verbo indica que a mão da personagem estava trêmula. Trata-se de uma característica psicológica que a personagem apresentava naquele momento: trêmulo, nervoso, ansioso. O que definirá a função caracterizadora de um verbo é, principalmente, o contexto em que se insere e os significados evocados pela carga semântica de determinado lexema.

O mesmo já observamos em relação à função expressiva dos substantivos. Lapa (1998) diz que certas palavras já expressivas caracterizam-se por si só. O exemplo, dado pelo autor, é a palavra antros. O uso de adjetivos para caracterizá-la é dispensável, visto que o substantivo já remete a um lugar fechado, escuro, asqueroso.

O uso dos verbos ou dos substantivos na descrição modifica a perspectiva da representação imaginativa da cena. Para Monteiro (2009, p. 113), "a representação da realidade efetiva-se através de uma visão estática ou dinâmica." Para o autor, os verbos constroem uma representação dinâmica, cinética, enquanto os substantivos demonstram uma representação estática. Ainda segundo Monteiro (2009), frases 
nominais permitem que sejam projetados nas descrições cada elemento da imagem projetada, o que favorece os aspectos sensoriais.

Retomando o conto $A$ caçada, podemos observar o uso dos substantivos nessas construções frasais que convergem, justamente, para imagem estática da cena representada:

Em redor, tudo parado. Estático. No silêncio da madrugada, nem o piar de um pássaro, nem o farfalhar de uma folha. (TELLES, 2009, p. 72)

As unidades lexicais que constituem o período contribuem para o efeito de sentido do texto. O uso de substantivos e a substantivação dos verbos no lugar de frases verbais fazem com que o leitor projete a cena como uma pintura, uma imagem estática, remetendo aos sentimentos que a personagem vive no conto. Como explica Monteiro:

Às vezes, as construções nominais se encaixam numa sequência de frases verbais que sustentam o fio narrativo, como se o ambiente passasse a influir na própria ação. Essa técnica aguça a capacidade imaginativa, levando o leitor a visualizar nitidamente os objetos descritos (2009, p. 114).

É o que ocorre em A caçada, em que o ambiente é o elemento central de todo o conto.

Podemos concluir, dessa forma, que os elementos descritivos de um texto podem ser elaborados por meio do uso de substantivos, adjetivos e verbos (em menor escala). Esse uso fica condicionado à intenção do escritor e o efeito de sentido pretendido ao realizar a descrição de uma personagem ou de um ambiente, pois, a descrição exerce papel fundamental no sentido global do texto. Por isso a observação desses elementos é de extrema importância quando desejamos realizar uma leitura mais eficiente. 


\section{CAPÍTULO IV - ENCAMINHAMENTOS DIDÁTICOS:}

\section{O CONTO EM CENA}

\subsection{Definição do conto e suas características}

Quando Mário de Andrade escreveu o conto Vestida de Preto, iniciou-o com a seguinte frase: "Tanto andam agora preocupados em definir o conto que não sei bem se o que vou contar é conto ou não, sei que é verdade." Muitos teóricos buscaram definir o conto à medida que esse gênero ganhava mais notoriedade no meio literário. Gotlib (2002), ao buscar uma solução para o questionamento do que seria um conto, lembra que sua tradição começou oralmente, desde as sociedades primitivas. Cada civilização, cada cultura, desenhou seu modo de contar histórias, o que faz com que seja muito mais complexo atingir uma definição exata para o gênero conto.

Ao se tomar como ponto de partida o contar histórias como definição para o conto poder-se-ia enumerar uma série gigantesca de textos que correspondem a esse conceito, como os mitos, os contos maravilhosos, as fábulas, alguns episódios bíblicos, as histórias contadas no Oriente etc. Tendo uma gama de textos tão diferenciada, esse ponto de vista para a definição do gênero ainda é bastante nebuloso.

Portanto, tarefa muito mais expressiva seria observar suas delimitações, ou como diz Passos (2001, p. 67) "em se tratando de conto, devemos aceitar as restrições de um estudo sobre traços que o delineiam". Dessa forma, os estudiosos do conto passaram a compará-lo com outros gêneros, observando suas especificidades.

Para Moisés (1967, p. 37) "o conto é, do prisma de sua história e de sua essência, a matriz da novela e do romance, mas isso não significa que deva poder, necessariamente, transformar-se neles". Na mesma linha de pensamento, do conto comparado ao romance, citamos novamente Passos $(2001,67)$, que diz "comparado ao romance, o conto configura-se breve e condensado, estando, em certos casos, próximo de outra forma de grande presença histórica, mas de perfil igualmente difícil, a novela". Há entre esses dois autores, apesar do largo espaço de tempo de 
seus estudos, um consenso de uma delineação do conto: história que não deve ter grande extensão. Esse é um ponto de comum acordo entre os teóricos do conto, que, ao delineá-lo, não deixam de citar sua forma intensa e breve.

De fato, esse passou a ser o conceito mais marcante para o gênero em questão, um texto narrativo em que os acontecimentos e os conflitos decorrem de forma breve, mas que causam forte impacto ao leitor. Como acrescenta Lucas:

\begin{abstract}
A dimensão do conto e a particularização de seu conflito fizeram-no distinguir-se da outra grande forma narrativa, o romance: enquanto este, dadas a complexidade da ação e a metamorfose de relações que o torna homólogo à própria sociedade, que se vê transcrita repetidas vezes no relato romanesco, aquele tende a captar a individualidade. (1982, p. 105)
\end{abstract}

Em seu conhecido estudo, Alguns Aspectos do Conto, Julio Cortázar faz a mesma analogia, e utilizando uma metáfora para referir-se a intensidade que abarca o conto, diz que o texto trava um combate com o leitor, nessa luta o romance ganharia por pontos enquanto o conto ganha por nocaute (CORTÁZAR, 2013).

Esse contista e teórico buscou nos ensaios e nos contos de Edgar Allan Poe as características que faziam de um texto um bom conto. Entre elas, Cortázar destaca a intensidade como acontecimento puro. O autor cita o exemplo da descrição dos ambientes que nos obriga a ler o conto como se estivéssemos dentro dele (CORTÁZAR, 2013). Segundo Passos (2001), cada palavra escrita no conto deve contribuir para esse acontecimento, todos os eventos do conto devem girar em torno de um efeito único de sentido, um desígnio preestabelecido.

Essas definições do gênero marcam não somente sua ruptura com o romance, mas também afastam o conto moderno dos antigos contos de tradição oral, alguns conhecidos como contos maravilhosos, estudados detalhadamente pelo russo Vladmir Propp, cujas características apontadas em seu estudo não mais se aplicam aos contos como conhecemos hoje. Basta pensarmos nos termos da língua inglesa que tem um nome diferente para cada uma dessas histórias, sendo o conto de tradição oral tale, e o conto praticado por Poe no século XIX, short-story. Gotlib (2002) aponta que o termo short-story, escrito com hífen, foi primeiramente utilizado por Brander Matthews, pois este queria diferenciar não só a extensão do conto (utilizando o termo short story, sem hífen), mas a sua natureza (GOTLIB, 2002). 
Historicamente, muitas formas assumiram o nome de conto. Ao pensarmos numa definição que contemple os contos em circulação na atualidade, considera-se a história de breve extensão, cujo tempo, personagens, espaço, situação, contribuem para a unidade de sentido, capaz de causar forte impacto.

Enquanto gênero textual, observa-se também uma grande diversidade de contos. $\mathrm{Na}$ escola, as crianças, provavelmente, têm o primeiro contato com o gênero pela oralidade, por meio dos contos de fadas. Ao ingressarem no Ensino Fundamental II, os alunos ampliam seu repertório com a leitura, interpretação e análise de contos maravilhosos. À medida que avançam nas séries escolares, outros textos literários vão adentrando o universo dos estudantes, como poemas, histórias de terror e de mistério, crônicas, entre outros, convivendo com outros gêneros que não pertencem à esfera literária. $O$ conto literário (como vamos nos referir ao gênero que vamos trabalhar na proposta didática) costuma ser abordado no $9^{\circ}$ ano do Ensino Fundamental II. Nesse segmento, espera-se que os alunos leiam, interpretem e analisem esses textos, assim como possam reconhecer os elementos composicionais desse gênero.

A definição do conto, feita para os alunos, também começa por sua extensão. O conto é apresentado como uma história curta, organizado numa tipologia narrativa. A fim de compreender como a teoria do conto é transmitida aos educandos, observamos como o conceito do conto e as atividades sobre o gênero se apresentam em dois livros didáticos em que estão presentes contos literários.

No livro Jornadas.port - Língua Portuguesa, do $9^{\circ}$ ano, elaborado por Dileta Delmanto e Laiz B. de Carvalho, o conto literário inicia a primeira unidade. O texto em análise é o conto Piquenique, de Moacyr Scliar. Os exercícios presentes na seção "Como o texto se organiza", trazem em seu enunciado ou em boxes explicativos algumas definições conceituais. O conto é definido como "narrativa breve em que a ação é o elemento mais importante. Por isso a caracterização das personagens, do espaço e do tempo é restrita (DELMANTO e CARVALHO, 2012, p. 19)". Nota-se que essa definição traz uma observação que vai de encontro com o trabalho proposto na presente pesquisa.

O problema de tal definição é achar que todo o conto, devido a sua brevidade, abre mão da caracterização. Já citamos o trabalho de Cortázar (2013) em que o autor escreve sobre a intensidade do conto. Para ele, a intensidade pode ocorrer de 
duas maneiras. A primeira consiste, como diz o autor, na eliminação de todas as ideias ou situações intermédias, nesse caso, o autor pode renunciar, inclusive, a descrição dos ambientes. Já na segunda maneira, o escritor aproxima lentamente o leitor do que está sendo contado. Esse tipo de intensidade também é chamado de tensão. Nessa modalidade, Cortázar (2013) observa que o leitor, mesmo longe de saber o que vai ocorrer no conto, não pode subtrair-se da atmosfera.

A definição do livro Jornadas.port, portanto, não estaria de acordo com os contos em que o autor faz uso da tensão para entreter o leitor. É difícil mesmo saber se está de acordo com o próprio conto analisado, pois na seção destinada à análise dos recursos linguísticos, um dos exercícios propõe a observação da adjetivação na caracterização das personagens. Como podemos observar:

3. O uso da adjetivação no conto é responsável pela caracterização das personagens. Observe como o narrador descreve o delegado e as demais personagens.

\begin{tabular}{|l|l|}
\hline O delegado & Os habitantes da cidade \\
\hline $\begin{array}{l}\text { - alto, forte, a espingarda na } \\
\text { mão }\end{array}$ & $\begin{array}{l}\text { - vivíamos em boa paz } \\
\text { - o barbeiro: chefe de família, muitos filhos }\end{array}$ \\
$\begin{array}{l}\text { - ora novo em nossa cidade } \\
\text { - o rosto impassível do } \\
\text { homem alto }\end{array}$ & $\begin{array}{l}\text { de suor } \\
\text { - rostos apreensivos, olhos esbugallhados, testa coberta } \\
\text { - ficamos inteiriçados chorosas }\end{array}$ \\
\hline
\end{tabular}

a) Pelos adjetivos e locuções adjetivas empregados, o que podemos deduzir quanto ao comportamento da população?

\section{NATO DEIXE DE OUVIR}

- Contos de aprendiz, de Carlos Drummond de Andrade, audiolivro, editora Luz da Cidade

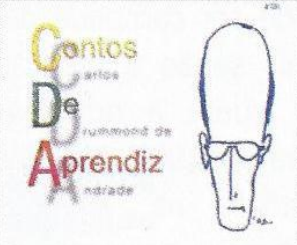

s Leonardo Vieira

b) Em sua opinião, por que há maior caracterização da população do que do "delegado"? se desenvolve em torno da passividade e ingenuidade dos habitantes $^{2}$ diante do golpe aplicado pelo suposto delegado.

4. Advérbios, além de indicar circunstâncias de tempo, modo, lugar etc., podem também expressar informações implícitas. Releia.

Habilidade em foco: Identificar o efeito de sentido produzido em um texto literário pela exploracão de recursos morfossintáti$\cos$.

Figura 01: Exercício do livro didático Jornasdas.port (p.21)

Esse exercício mostra, inclusive, como essa adjetivação contribui com o efeito de sentido do texto, revelando o comportamento da população da cidade, como é analisado pelas próprias autoras na sugestão de resposta oferecida pelo Manual do Professor do livro didático em questão: "No conto, é importante caracterizar a população, pois o conflito se desenvolve em torno da passividade e ingenuidade dos habitantes diante do golpe aplicado pelo suposto delegado" (DELMANTO E CARVALHO, 2012, p.21). 
Esse é um problema o qual nos referimos na apresentação do presente estudo: temos recursos lexicais que podem ser explorados no texto a fim de averiguar como contribuem para seu efeito de sentido, contudo, o estudo lexical ganha pouco espaço nos materiais didáticos. Embora o exercício apresentado seja um excelente exemplo de trabalho com os recursos lexicais e estilísticos do texto, a seção que segue, intitulada "Reflexão sobre a língua", trata da formação de palavras. Uma segunda leitura de um conto também é proposta com o texto Bárbara, de Murilo Rubião, dessa vez as atividades se apresentam em menor número, trabalhando com a interpretação do texto e com algumas noções do conto fantástico, retornando novamente para outros processos de formação de palavras.

O outro exemplar didático observado foi o livro Português: linguagens, também do $9^{\circ}$ ano, de William Roberto Cereja e Thereza Cochar Magalhães. Nesse livro didático, o trabalho com o conto começa na segunda unidade do livro. $O$ texto trazido pelos autores é o conto Felicidade Clandestina, de Clarice Lispector, e, num segundo momento, o texto Pausa, de Moacyr Scliar. Os autores apresentam a seguinte definição para o conto:

Como a crônica, o conto é um texto curto que pertence ao grupo dos gêneros narrativos ficcionais. Caracteriza-se por ser condensado, isto é, por apresentar poucas personagens, poucas ações e tempo e espaço reduzidos (CEREJA e MAGALHÃES, 2012, p. 74).

Por tratar o conto como gênero narrativo ficcional, a ênfase do trabalho didático é dada aos elementos narrativos do texto, o tempo, o espaço, a estrutura do enredo, o foco narrativo etc. Esses elementos são explorados na análise do texto como parte constitutiva do sentido, sobretudo na compreensão do conto Pausa. Os autores afirmam que a caracterização do espaço nesses gêneros é reduzida ao essencial, mas também observam que a descrição do hotel, feita em pormenores pelo narrador, associa-se ao espaço de isolamento da personagem, portanto relaciona-se com suas ações e ao título do conto. Como podemos observar na parte explicativa do livro didático destinada ao aluno: 


\section{espaço}

Os fatos de uma narrativa relacionam-se com o espaço em dois níveis:

\section{Espaço físico ou geográfico}

É o lugar onde acontecem os fatos que envolvem as personagens: uma rua movimentada, uma cidade, um cinema, uma escola, um cômodo de uma casa, etc. O espaço pode ser descrito detalhadamente ou suas características podem aparecer diluídas na narração. A história do conto "Pausa" se inicia na casa da personagem, mas o espaço privilegiado da narração é o hotel, que é descrito em pormenores pelo narrador.

\section{Espaço social (ambiente)}

É o espaço relativo às condições socioeconômicas, morais e psicológicas que dizem respeito às personagens. O espaço social situa as personagens na época, no grupo social e nas condições em que se passa a história. No conto "Pausa", o hotel é um espaço de isolamento da personagem; nesse lugar, a personagem Samuel cede lugar a Isidoro, que dorme e sonha.

Figura 02: Fragmento da parte teórica sobre o conto do livro didático Português: linguagens (p.94).

A abordagem do conto feita pelos autores é bastante produtiva, primeiro eles apresentam um exemplo do gênero, depois discutem as características específicas da sua narrativa, exemplificando como a descrição do espaço influencia no sentido global do texto. Definem o conto como texto de pouca extensão, com tempo e espaço reduzidos e, na análise do conto Pausa, não deixam de considerar a importância do ambiente para o significado do texto.

Já no conto, Felicidade Clandestina, as personagens é que ganham destaque na caracterização como produção de efeito de sentido. Os alunos são levados a observar as características da personagem protagonista e da personagem antagonista desde a primeira questão de compreensão do texto. Na seção referente à "Linguagem do texto", um dos exercícios proposto chega a explorar o campo semântico de adjetivos e substantivos abstratos que fazem referência a filha do dono da livraria, mostrando como a criança é retratada como uma pessoa cruel e que se diverte com o sofrimento alheio. Conforme reproduzimos a seguir: 


\section{A LINGUAGEM DO TEXTO}

1. Para caracterizar a filha do dono de livraria, a narradora emprega palavras e imagens que se relacionam quanto ao sentido e, por isso, fazem parte do mesmo campo semântico. Observe:

"Mas que talento tinha para a crueldade.

"Ela toda era pura vingança"

"Comigo exerceu com calma ferocidade o seu sadismo."

"O plano secreto [...] era tranquilo e diabólico."

"enquanto o fel não escorresse todo de seu corpo grosso"

a) O que essas palavras têm em comum, quanto ao sentido?

b) Que efeito de sentido esse campo semântico tem na caracterização da personagem?

Figura 03: Exercício do livro didático Português: linguagens (p.73).

Percebemos que a abordagem utilizada pelos autores contribui para que 0 aluno observe que as escolhas lexicais do autor são intencionais e confluem para a caracterização da personagem, que apesar de criança, mostra-se malvada e sádica com a colega. Percebe-se também de que forma o exercício destacou adjetivos, substantivos abstratos e outras expressões para mostrar como foi construída a descrição dessa personagem, tomando como parâmetro o sentido das unidades lexicais selecionadas na construção do texto, agrupando-as em um mesmo campo semântico.

A proposta desse exercício, que é trabalhar a linguagem do texto, é coerente com as demais atividades sobre o conto Felicidade Clandestina. O exercício está relacionado ao texto, e a abordagem lexical colabora com a compreensão textual. $O$ livro didático Português: linguagens traz, portanto, um bom exemplo de como podemos trabalhar com conto literário em sala de aula.

Nesse mesmo nesse exemplar de livro didático, também figura um excerto de um dos contos de Lygia Fagundes Telles. Um fragmento do conto $O$ Menino está presente, com o objetivo de trabalhar o discurso indireto livre no texto.

As atividades observadas nesses livros didáticos mostram como o estudo lexical contribui para a compreensão de textos como o conto literário. Pode-se perceber que observar a caracterização nos contos é importante para estabelecer os efeitos de sentido desse gênero, sobretudo a caracterização do ambiente e das personagens. 
Constatada tal importância, buscaremos observar como pode ser feita a análise do conto do ponto de vista lexical. Para isso, nos próximos itens, iremos analisar três contos de Lygia Fagundes Telles: A caçada, Verde lagarto amarelo e Natal na barca.

\subsection{A Caçada: Caçando... Ou sendo caçado?}

A caçada narra a história de um homem que vai a uma loja de antiguidades para observar uma tapeçaria que the causa sentimentos estranhos, como se a imagem retratada causasse-lhe um déjà-vu. No conto, temos apenas duas personagens: o homem e a velha senhora, dona da loja de antiguidades, que pouco aparece na história. A maior parte do conto centra-se na narração da confusão que o homem tem ao se deparar com a imagem da tapeçaria: dois caçadores, um com o arco em punho, outro espreitando entre as árvores, constituindo a cena de uma caçada.

Nesse conto, temos três elementos centrais na parte descritiva, o primeiro é o da ambientação, constituindo a loja de antiguidades e a tapeçaria. O segundo elemento descrito é o caçador que aparece em primeiro plano na cena, e o terceiro elemento é o homem que vai à loja para observar a tapeçaria, personagem principal do conto.

Logo no início do conto, a autora já proporciona ao leitor o cenário da narrativa:

\footnotetext{
A loja de antiguidades tinha o cheiro de uma arca de sacristia com seus panos embolorados e livros comidos de traça. Com as pontas dos dedos, o homem tocou numa pilha de quadros. Uma mariposa levantou vôo e foi chocar-se contra uma imagem de mãos decepadas (TELLES, 2009, p. 67).
}

Há uma descrição sensorial nesse trecho do conto. A autora explora o olfato, o tato e a visão e aos poucos vai envolvendo o leitor, assim como o protagonista está sendo envolvido pela tapeçaria. Também há outro momento em que os sentidos olfativos do leitor são convocados para percepção do ambiente: "E aquele cheiro de folhagem e terra? De onde vinha aquele cheiro?" (TELLES, 2009, p. 72). 
Constantemente, os outros sentidos são retomados na descrição da tapeçaria, sobretudo a visão.

Para Micheletti (2012) a descrição inicial do espaço transmite símbolos que o leitor decodificará ao longo da narrativa em um processo de construção de sentido. Segundo a autora:

A colocação da tapeçaria em uma loja de antiguidades remete ao passado, uma arca de sacristia, determinado sagrado, afinal também presente na imagem de mãos decepadas - um São Francisco (santo que, para os católicos, é protetor dos animais). As mãos decepadas, uma impossibilidade de ação. O humano - os livros - estão comidos de traça (MICHELETTI, 2012, p. 77- grifos da autora).

A descrição da tapeçaria vai se intensificando ao longo da narrativa. Quanto mais a personagem observa a cena da caçada, mais nítida a imagem vai ficando. $A$ cor da tapeçaria é retomada de forma recorrente. $O$ tom de verde utilizado na descrição é bastante escuro, o que reforça o ambiente sombrio do bosque. Observamos no quadro abaixo as palavras que descrevem a tapeçaria:

\begin{tabular}{|c|c|c|}
\hline \multicolumn{3}{|c|}{ DESCRIÇÃO DA TAPEÇARIA } \\
\hline \multicolumn{3}{|c|}{ Palavras com função caracterizadora utilizadas no conto } \\
\hline Adjetivos & Substantivos & Verbos \\
\hline Nítido (a) & Touceira & Envenenando \\
\hline Puída & Árvores & Devorando \\
\hline Vivas & Bosque & \\
\hline Estragado & Céu & \\
\hline Espessa & Tempestade & \\
\hline Esverdeada & Manchas & \\
\hline Verde-musgo & Folhagem & \\
\hline Negro-violáceo & Caçador & \\
\hline Maligno & Perfume (dos eucaliptos) & \\
\hline Próximo (a) & Frio & \\
\hline Úmido & Madrugada & \\
\hline Denso & Vereda & \\
\hline Verde & Vapor & \\
\hline
\end{tabular}




\begin{tabular}{|l|l|l|}
\hline Sombrio & Folhas & \\
Verde-negro & Silêncio & \\
Detestável & Sombra & \\
(cores) Fortes & Trapo & \\
Empastadas & Cheiro & \\
& Folhagem & \\
& Terra & \\
& Penumbra & \\
\hline
\end{tabular}

Temos, novamente, o uso da descrição sensorial, como o uso da palavra úmido (tato) e da palavra perfume (olfato). A descrição aguça os sentidos do leitor, que é transportado para o bosque. Também percebemos o uso de palavras que ressaltam o ambiente ameaçador, carregado, sinistro: as cores escuras, como já mencionamos, e os vocábulos sombra, tempestade, denso, silêncio, maligno, espessa, frio, madrugada etc.

Outras palavras caracterizadoras com efeitos bastante expressivos são utilizadas na descrição dos caçadores. O caçador em segundo plano fica reduzido a um mero contorno, enquanto a figura do caçador em primeiro plano é ressaltada, um homem forte e intimidador.

\footnotetext{
"Era uma caçada. Em primeiro plano, estava o caçador de arco retesado, apontando para uma touceira espessa. Num plano mais profundo, o segundo caçador espreitava por entre as árvores do bosque, mas era uma vaga silhueta cujo rosto se reduzira a um esmaecido contorno. Poderoso, absoluto era o primeiro caçador, a barba violenta como um bolo de serpentes, os músculos tensos, à espera de que a caça levantasse para desferir-lhe a seta" (TELLES, 2009, p. 68 - grifos nossos).
}

Nesse fragmento temos um forte recurso estilístico, o uso dos adjetivos antepostos. Primeiramente temos o apagamento do segundo caçador, a vaga silhueta e o esmaecido contorno contrastam com as características do primeiro caçador. Nota-se que em ambos os casos os adjetivos estão antepostos, o segundo caçador fica reduzido a um borrão, sem, contudo, deixar que sua presença não seja percebida, para que os adjetivos que se referem ao primeiro caçador ganhem ainda 
mais força quando postos em comparação na descrição do companheiro de caçada. A posição dos adjetivos poderoso e absoluto, nesse caso, realça as características do caçador, enfatiza seu poder e sua força em relação ao ser que está sendo caçado.

Outro recurso importante nesse mesmo trecho é o adjetivo utilizado para caracterizar a barba do caçador: violenta. Esse não é um adjetivo utilizado comumente para caracterizar esse substantivo. Esse adjetivo sugere que algo ou alguém possa exercer força física sobre uma pessoa, portanto seu uso é bastante inusitado para caracterização da barba. A imagem da barba do caçador é frequentemente retomada no conto: "O caçador de barba encaracolada" (TELLES, 2009, p. 69), "o caçador de barba esgrouvinhada, só músculos e nervos..." (TELLES, 2009 , p. 70). A barba cheia, sem grandes cuidados estéticos, remete a imagem viril do caçador. Lamas (2004) também observa que a falta de cuidado com a barba, em determinadas culturas, está associada à loucura.

Por vezes, a referência é substituída pelo uso do substantivo serpentes "No fundo, lá no fundo do fosso podia distinguir as serpentes enleadas num nó verdenegro" (TELLES, 2009, p. 71). Sobre o uso desse substantivo, Lamas explica:

A comparação da barba com um emaranhado de serpentes conduz a um caráter indiferenciado e animalesco: ele mais parece uma cobra pronta a dar seu bote. As serpentes representam forças inconscientes - difíceis de controlar racionalmente (2004, p.161).

Para Lamas (2004), o entrelaçamento dos fios remete ao simbolismo da Medusa. O caçador seria uma espécie de "medusa ao contrário", uma vez que o bolo de serpentes está em sua barba e não em seus cabelos, daí a paralisação da personagem frente à imagem da tapeçaria.

O substantivo serpente nos remete à imagem de uma caçadora exímia, rápida e venenosa, enquanto o adjetivo violenta reforça a brutalidade do caçador. Temos, portando, duas escolhas lexicais intencionadas a conferir maior expressividade ao conto. Nessa descrição, as características físicas remetem aos aspectos comportamentais da personagem.

Observamos um jogo de contrastes no conto de Lygia Fagundes Telles. Propositalmente, a personagem protagonista do conto é descrita com palavras que 
revelam o comportamento da caça, que se sente ameaçada, indefesa, com medo; características que vão delineando o desfecho do conto:

O homem estava tão pálido e perplexo quanto à imagem" (TELLES, 2009, p. 68 - grifos nossos).

"Sua mão tremia (TELLES, 2009, p. 68 - grifo nosso).

Saiu de cabeça baixa, as mãos cerradas no fundo dos bolsos. Parou meio ofegante na esquina. Sentiu o corpo moído, as pálpebras pesadas (TELLES, 2009, p. 70 - grifos nossos).

"Conheço o caminho", repetiu seguindo lívido por entre os móveis (TELLES, 2009, p. 72 grifo nosso).

Percebemos o uso de verbos caracterizadores nesse conto, como mostra o segundo exemplo, que ressalta a mão trêmula do homem que visita a loja de antiguidades. Vale relembrar que os verbos com essa função podem ser encontrados em diferentes formas, sejam elas nominais ou não, dependendo do sentido e do contexto em que estão empregados.

Aos poucos, a narrativa começa a mostrar por meio dos recursos de caracterização que aquele homem é, na verdade, a caça. O adjetivo arquejante que é atribuído a caça no meio do conto, é depois atribuído ao homem no desfecho, corroborando a ideia da metamorfose:

Mas detrás das folhas, através das manchas pressentia o vulto arquejante da caça (TELLES, 2009, p. 70 - grifo nosso).

Inclinou-se arquejante. Era o caçador? Ou a caça? (TELLES, 2009, p. 72 - grifo nosso).

Para Silva (1985) a atribuição de certas expressões à personagem contribuem para a ambiguidade do texto, uma vez que as palavras que são utilizadas para caracterização se referem tanto a um animal, quanto a um ser humano, o que corrobora nosso argumento. Aos poucos, as cores se tornam mais nítidas, o passado vai sendo recobrado, o homem percebe-se em meio à caçada, mas na verdade está sendo caçado. 
Podemos observar como é construída a descrição da personagem principal no quadro que segue:

\begin{tabular}{|l|l|l|}
\hline \multicolumn{2}{|c|}{ DESCRIÇÃO DO PROTAGONISTA } \\
\hline \multicolumn{2}{|c|}{ Palavras com função caracterizadora utilizadas no conto } \\
\hline Pálido & \multicolumn{1}{|c|}{ Substantivos } & \multicolumn{1}{c|}{ Verbos } \\
Perplexo & Pânico & Tremia \\
Arquejante & Suor & Murmurou \\
(cabeça) Baixa & Náusea & Enxugando (referente ao suor) \\
Ofegante & Insônia & Vagou \\
Moído & Escuridão & Cambaleou \\
(pálpebras) Pesadas & Viscosidade & Gritou \\
Desamparado & Sangue & Gemeu \\
(olhos) Escancarados & Dor & \\
Molhado & & \\
Lívido & & \\
Esgazeado & & \\
(cara) Esbraseada & & \\
(lábio) Gretado & & \\
Encolhido & & \\
\hline
\end{tabular}

Em $A$ caçada, os elementos de caracterização são amplamente utilizados e pode-se mostrar ao aluno como a descrição não é feita unicamente com a estrutura comum SUBSTANTIVO + ADJETIVO. Lapa (1998) diz que o uso excessivo de adjetivos é condenável no texto literário e, muitas vezes, dispensável. Como já mencionamos, ele analisa que algumas palavras como já são expressivas, portanto caracterizam-se por si próprias, caso do lexema antros, que já havíamos citado, e de outros lexemas que o autor também fornece em seu estudo, como crime e miséria, por exemplo.

É importante explorar com os alunos, a cada exemplo mostrado, que as descrições realizadas no conto não utilizam apenas adjetivos. Outros instrumentos de caracterização também são importantes na construção da parte descritiva do conto, o que garante a expressividade do texto. É a caracterização que permite que percebamos a transfiguração do homem em caça. É por meio da descrição que a 
tapeçaria vai invadindo o ambiente da personagem que a admira e, junto dela, somos também entrelaçados nos fios da narrativa.

\subsection{Verde Lagarto Amarelo: a disputa entre irmãos}

Em Verde Lagarto Amarelo temos a visita do irmão mais novo, Eduardo, a seu Irmão mais velho, Rodolfo. O conto é narrado por Rodolfo, que, transtornado pelas memórias que Eduardo Ihe traz da infância, sente-se incomodado com a presença do irmão e divaga em suas lembranças do passado. O que aparenta ser um encontro "banal" entre dois irmãos é na verdade uma batalha interior que Rodolfo trava. Para ele, Eduardo sempre foi o mais querido, o mais bonito, o mais amado pela sua já falecida mãe.

Durante o conto, Rodolfo descreve episódios do passado enquanto observa o irmão, magro, sempre limpo, bem vestido. Enquanto Rodolfo, gordo, estava sempre empapado de suor. O único mérito de Rodolfo é ser escritor. Com a morte da mãe, Eduardo ficara com o aparelho de chá, o faqueiro, os cristais, os tapetes, só Eduardo havia se casado. Em sua visão, Rodolfo nunca tivera o amor de sua mãe, assim como nunca teria o amor de Ofélia, esposa de Eduardo. Também não seria pai, mas Eduardo o convida para ser padrinho, notícia que não é bem recebida por Rodolfo. No desfecho do conto, Rodolfo descobre que esse convite não foi o motivo da visita. Percebendo uma pasta em poder de seu irmão, ele pergunta, como uma dor quase física, se Eduardo havia escrito um romance, Eduardo abre a pasta e o conto se encerra.

O tema central desse conto é a inveja. Rodolfo inveja o irmão, apesar de escritor bem sucedido, ele não se mostra para a sociedade, vive sozinho e escondido, como "um lagarto no vão do muro". Na infância, teve que lidar com o problema do suor excessivo, que deixava sua camisa manchada de amarelo com uma borda esverdinhada. A caracterização que Rodolfo faz de si é estritamente ligada ao lagarto:

Não queria suar, não queria mas o suor medonho não parava de escorrer manchando a camisa de amarelo com uma borda esverdinhada, suor de bicho venenoso, traiçoeiro, malsão. Enxugava depressa a testa, o pescoço, tentava num último esforço salvar ao 
menos a camisa. Mas a camisa já era uma pele enrugada aderindo à minha com meu cheiro, com minha cor (TELLES, 2009, p. 22 e 23).

A imagem do lagarto é o símbolo perfeito para representar a personagem. Silva (1985) evidencia que o aspecto do lagarto é aterrador, no entanto, é um ser tímido, tal qual Rodolfo. Devido à constante comparação entre os irmãos, o contraste das palavras com função caracterizadora é recorrente. Podemos observar adjetivos avaliativos, positivos e negativos, na caracterização das duas personagens centrais do conto na seguinte passagem do conto:

\footnotetext{
Era bonito, inteligente, amado, conseguiu sempre fazer tudo muito melhor do que eu, muito melhor do que os outros, em suas mãos as menores coisas adquiriam outra importância, como que se renovavam. E então? Natural que esquecesse o irmão obeso, malvestido, malcheiroso (TELLES, 2009, p.26).
}

No mesmo parágrafo três adjetivos são atribuídos para cada uma das personagens, Eduardo: bonito, inteligente, amado; Rodolfo: obeso, malvestido, malcheiroso. O conto é narrado por Rodolfo, portanto, as características presentes revelam a visão que essa personagem tem do irmão e como ele constrói sua autoimagem. $\mathrm{O}$ foco narrativo do conto só nos permite conhecer o ponto de vista do irmão mais velho. É comum, portanto, que algumas caracterizações apresentem certo exagero por parte dessa personagem, devido à baixa autoestima e ao sentimento de inveja que se instaura em Rodolfo.

Rodolfo é visto como um lagarto, o título Verde lagarto amarelo, apresenta esse substantivo entre dois adjetivos, além de fazer referência às características físicas desse animal, a posição dessa palavra demonstra também seu comportamento, é um ser que não quer se mostrar, que busca a invisibilidade, assim como o camaleão faz por meio das cores. A posição do substantivo entre dois adjetivos cria a imagem do vão, como já mencionamos, onde o lagarto se esconde.

No começo do conto temos a palavra felino associada à personagem Rodolfo. Apesar de o irmão dizer que ele não chegava a ser felino, a descrição e atitudes de Eduardo, como a de estar sempre rondando o irmão como um gato caçando um rato, mostram que é exatamente essa a comparação que the cabe. Isso pode ser 
nitidamente percebido no trecho "Engatinhava ainda quando saía à minha procura, farejando meu rastro (TELLES, 2009, p. 26)". Essa representação também é bastante simbólica. Primeiramente, o gato é associado à beleza. A imagem desse animal é admirada socialmente, é um bicho querido como animal de estimação, um ser amado. Ainda assim, os felinos também são popularmente conhecidos como egoístas e também podem ser traiçoeiros. Podem dar o bote quando menos se espera, ou mesmo arranhar quem sempre lhe agradou e demonstrou afeto. É o que vemos acontecer em Verde lagarto amarelo, Eduardo chega à casa de Rodolfo: "Ele entrou no seu passo macio, sem ruído, não chegava a ser felino: apenas um andar discreto. Polido" (TELLES, 2009, p. 19).

Logo no primeiro parágrafo do conto vemos que Eduardo vai cercando o irmão, prestes a lhe dar o bote, desferir-lhe um golpe, o que se concretiza no desfecho do conto, quando ele mostra o interesse em ser escritor, única qualidade de Rodolfo.

Essa relação também pode ser observada no trecho:

\footnotetext{
Era enjoativo de tão doce mas se eu rompesse a polpa cerrada e densa sentiria seu gosto verdadeiro. Com a ponta da língua pude sentir a semente apontando sob a polpa. Varei-a. O sumo ácido inundou-me a boca (TELLES, 2009, p.20).
}

Nesse fragmento, Rodolfo prova as uvas roxas trazidas pelo irmão. A fruta madura, doce, com polpa suculenta, revela que esconde uma semente de sumo ácido. Temos nesse trecho do texto nova referência à surpresa que Eduardo traz em sua pasta, algo que trará sofrimento ao irmão. Mais adiante, Rodolfo também diz ao irmão que ele tem olhos cor-de-violeta e depois que seus olhos têm o brilho úmido das uvas, ligando, novamente, as características da fruta a Eduardo. Nessa mesma frase também há uma analogia ao ofício do escritor. Após a observação do sabor da fruta, Rodolfo pensa: "[...] assim queria escrever, indo ao âmago do âmago até atingir a semente resguardada lá no fundo como um feto" (TELLES, 2009, p. 20). Ele almeja escrever assim, mas ainda não escreve. Poderia Eduardo superá-lo também nisso, como havia feito em tudo na vida?

A vista de Eduardo faz com que as memórias de Rodolfo sejam despertadas. $\mathrm{O}$ incomodo que a presença de Eduardo causa a Rodolfo ocorre porque este 
sempre se sentiu privado de tudo, por conta da presença do irmão. Nunca teve o amor de sua mãe, Eduardo andava sempre limpo, enquanto sua obesidade the causava suor excessivo. A mãe nem mesmo gostava de utilizar o verbo suar, ela substituía por transpirar, como forma de deixar a personagem menos desagradável e feia, como é narrado por Rodolfo no conto: "Minha mãe não usava a palavra suor que era forte demais para seu vocabulário, ela gostava de belas palavras. Das belas imagens (TELLES, 2009, p. 22)". Nunca pode, também, provar as uvas do jardim sem que estivessem verdes, Eduardo não deixava que elas amadurecessem. Estava sempre só, como ele mesmo diz ao irmão no início da visita, enquanto Eduardo representava o ideal da família, tinha esposa e um filho. Durante o chá, usa a xícara perfeita dada a ele pelo irmão, enquanto Rodolfo fica com a xícara rachada.

A relação de contrastes entre os irmão é facilmente notada quando observamos as palavras com função caracterizadora no conto. Com exceção da palavra escritor, que era a única qualidade de Rodolfo, os elementos que caracterizam Rodolfo são todos negativos. Já a caracterização de Eduardo é formada por elementos positivos, excetuando as palavras que fazem referência ao gato (felino, engatinhava, farejando). Consideramos que essas são características ambíguas, que podem ser positivas ou negativas, pois por um lado dizem respeito à beleza, à suavidade e à discrição de Eduardo, mas, por outro lado, também demonstram que ele pode ser traiçoeiro. O único vocábulo associado a Eduardo no conto que pode trazer um elemento negativo é a palavra malícia; todas as outras ressaltam suas virtudes, como podemos observar no quadro comparativo que segue:

\begin{tabular}{|l|l|}
\hline \multicolumn{1}{|c|}{ Eduardo (positivo) } & \multicolumn{1}{|c|}{ Rodolfo (negativo) } \\
\hline Polido & Sozinho \\
Olhos cor-de-violeta & Lagarto \\
Olhos com brilho úmido & Sofrimento \\
Menino & Vazio \\
Louro & Imobilidade \\
Pele bronzeada & Engordei \\
Mãos de estátua & Enorme \\
Braços musculosos & Mãos viscosas \\
\hline
\end{tabular}




\begin{tabular}{|l|l|}
\hline Pelos dourados & Olhos que ardiam \\
Limpo & Suor \\
Pãos sem poeira & Transpira \\
Resignado & Desagradável \\
Bom humor & Lustroso \\
Amável & Gordo \\
Amabilíssimo & Suor a escorrer \\
Olhos que riam & Sovacos \\
Bonito & Suar \\
Inteligente & Suor medonho \\
Amado & Bicho \\
Fraterno amor & Venenoso \\
Magro & Traiçoeiro \\
& Malsão \\
& Pele enrugada \\
& Suor amarelo-verde \\
& Cara ardente \\
& Esquisito \\
& Vil \\
& Obeso \\
& Malvestido \\
& Malcheiroso \\
& Cabeça baixa \\
& Calado \\
& Mãos em garra \\
& Imóvel \\
& Encolhido \\
& Escorrendo \\
Engordar \\
\\
\end{tabular}

As palavras eleitas para constituir o quadro foram as que estavam ligadas à aparência física ou ao comportamento das personagens. 
Vemos, portanto, que somente uma das palavras que caracterizam Eduardo pode ser considerada negativa (malícia), enquanto todas as outras palavras, com exceção das palavras ambíguas às quais já nos referimos, apontam para qualidades positivas, sobretudo enfatizando sua impecável aparência (bonito, magro, braços musculosos, limpo, mãos sem poeira etc.).

Em contrapartida, temos Rodolfo, cuja única característica positiva (escritor) está prestes a ser tomada pelo irmão. Alguns dos adjetivos e expressões que constituem a descrição dos personagens são exatamente o oposto do outro. Eduardo tem mãos perfeitas, mãos de estátua, enquanto Rodolfo tem mãos em garra, Eduardo é magro, Rodolfo gordo, obeso. Eduardo é limpo, Rodolfo é malcheiroso.

É importante ressaltar que o foco narrativo desse conto é em primeira pessoa. Quem narra e, portanto, atribui essas características aos personagens, é o próprio Rodolfo. O conto mostra como Rodolfo se sente inferior ao irmão, como criou uma imagem negativa de si desde a infância, que só piorou com o passar dos anos. Todas as escolhas lexicais feitas pela autora na constituição das personagens, todos os contrastes utilizados, contribuem para que o desfecho da narrativa seja tão avassaladora para o leitor, quanto é perturbadora para Rodolfo, mostrando, mais uma vez, toda intencionalidade de Lygia Fagundes Telles ao usar as palavras com função caracterizadora.

É importante mostrar ao aluno a influência do narrador nesse conto. Observamos o grande número de elementos negativos referentes a Rodolfo, mas não podemos deixar de nos atentar ao fato de que essa descrição é feita pela própria personagem. Essa informação é bastante relevante na interpretação do conto. O aluno, como leitor atento, deve considerar que possa existir certo exagero por parte de Rodolfo ao se descrever e ao descrever seu irmão.

O aluno pode observar, com a análise desse conto, que as palavras com função caracterizadora são marcadas pelo contraste. Essa oposição é de fundamental importância para compreensão do enredo. É por meio dela que percebemos os sentimentos de Rodolfo e a visão que ele projetou do irmão Eduardo. São os elementos lexicais que explicitam o tema central do conto: a inveja. É por meio da descrição das personagens que podemos vivenciar a experiência de 
Rodolfo, compartilhar seus sentimentos e, junto com ele, sofrer com a surpresa escondida na pasta de Eduardo.

\subsection{O jogo de contrastes em Natal na Barca}

O conto Natal na Barca narra a viagem de quatro passageiros, uma mulher que traz consigo uma criança de colo, um velho bêbado e a narradora, em uma embarcação velha e desconfortável.

Durante o percurso, a narradora, mesmo evitando o contato verbal com os outros passageiros, acaba se envolvendo num diálogo com a jovem mulher que carrega a criança. Ela descobre que a mulher foi deixada pelo marido, perdera o primeiro filho e o que embalava naquele momento encontrava-se muito doente. Apesar de todos os infortúnios enfrentados, a mulher demonstra ter uma fé inabalável. Em determinado momento a narradora percebe que o menino que essa mulher segurava estava morto. Sem ter coragem de fazer tal anúncio, fica desesperada e tenta deixar a barca antes que a mãe perceba a morte de seu segundo filho. Contudo, ao saírem da barca a mulher revela que o filho acordou e já não tem mais febre, deixando a narradora atônita e confusa, sem saber se havia ou não presenciado um milagre de Natal.

Os adjetivos têm presença fundamental na narrativa desse conto. Todo o conto é envolto por uma atmosfera mística, a começar pela descrição da embarcação:

Debrucei-me na grade de madeira carcomida. Acendi um cigarro. Ali estávamos os quatro, silenciosos como mortos num antigo barco de mortos deslizando na escuridão. Contudo, estávamos vivos. E era Natal (TELLES, 2009, p. 116).

A embarcação é descrita pela narradora como a barca conduzida por Caronte para fazer a travessia dos mortos para o outro mundo, segundo a mitologia grega. Em outras passagens do conto, o ar sóbrio e rústico do ambiente é novamente ressaltado por meio dos instrumentos de caracterização utilizados para descrever a barca, como vemos logo no primeiro parágrafo: 
Não quero nem devo lembrar aqui por que me encontrava naquela barca. Só sei que em redor tudo era silêncio e treva. E que me sentia bem naquela solidão. $\mathrm{Na}$ embarcação desconfortável, tosca, apenas quatro passageiros. Uma lanterna nos iluminava com sua luz vacilante: um velho, uma mulher com uma criança e eu (TELLES, 2009, p.115 - grifos nossos).

Devemos lembrar que, de acordo com Martins (2012), os substantivos abstratos exercem função caracterizadora por destacar o sentimento, a qualidade e o estado, Ihes dando realce. É o que acontece no fragmento supracitado, as palavras silêncio, treva e solidão, tem função adjetiva no texto, a escolha desses itens lexicais imprime ao cenário da narrativa um tom escuro, sombrio, ressaltado pela imagem antiga da barca e pela falta de iluminação, elementos descritos posteriormente por meio dos adjetivos, desconfortável, tosca e a luz vacilante da lanterna. A impressão negativa que a narradora mantém da embarcação é outras vezes retomada no conto com as expressões barca tão despojada, tão sem artifícios, chão de largas tábuas gastas, ou o sulco negro que a embarcação ia fazendo no rio e também grade de madeira carcomida. Temos, nessas expressões, a presença de adjetivos e locução adjetiva que possui um elemento avaliativo negativo, como: despojada (no sentido de sóbrio, sem enfeites), sem artifícios, gastas, negro e carcomida.

Tais impressões também revelam informações sobre a narradora. Sendo dela o ponto de vista pelo qual a história é contada, percebemos que, mesmo sem uma descrição direta, esses elementos vão caracterizando essa personagem e fornecendo ao leitor informações sobre ela. Segundo Micheletti:

O ambiente criado pela narradora desde o início foi o de negatividade: não queria falar, não queria compartilhar o momento da travessia, negatividade que se acentuou com as palavras e expressões sobre o que se passava ao seu redor: silêncio, treva, solidão, desconfortável, tosca, não fazer nada, não dizer nada. Todas carregadas de uma valoração negativa e representando, de certa maneira, a visão da personagem sobre o mundo exterior. Essa visão negativa associada ao aparente desejo de inação - não lembrar, não fazer, não dizer cria uma atmosfera sombria que corrobora com a imagem de uma personagem em conflito e angustiada (2012, p. 87 - grifos da autora). 
Com as palavras realçadas por Micheletti, é possível delinear um campo associativo que traz características psicológicas da personagem que narra: angústia, desesperança, sofrimento. Em oposição a essa personagem, apresenta-se a mulher que carrega a criança. Há na apresentação dessas duas personagens um jogo de contrastes no conto, ora lúgubre e nebuloso, pela visão da narradora, ora claro e iluminado na medida em que a jovem mulher é apresentada.

No conto, são dadas várias informações sobre a segunda personagem, começando pela sua aparência física, como vemos no trecho a seguir:

A mulher estava sentada entre nós, apertando nos braços a criança enrolada em panos. Era uma mulher jovem e pálida. O longo manto escuro que lhe cobria a cabeça dava-lhe o aspecto de uma figura antiga (TELLES, 2009, p. 115 - grifos nossos).

A forma como a personagem é retratada no conto nos faz vislumbrar a mulher quase como uma pintura da Virgem Maria. O modo como carrega seu filho, enrolado em panos, mostra também se tratar de uma pessoa simples, pobre, com roupas puídas, como é descrita também no trecho "Como se não bastasse a pobreza que espiava pelos remendos da sua roupa [...]" (TELLES, 2009, p. 118), contudo a imagem que prevalece é sempre a de uma bela mulher calma e serena que transmite uma representação de otimismo, de fé, destacada pelas palavras com que essa personagem se associa, que, diferentemente da narradora, trazem quase sempre a imagem de claridade, por mais que sucessivas tragédias tenham assolado a vida dessa mulher. É o que observamos no fragmento:

Voltei-me para a mulher que embalava a criança e me observava com um meio sorriso. Sentei-me no banco ao seu lado. Tinha belos olhos claros, extraordinariamente brilhantes. Vi que suas roupas puídas tinham muito caráter, revestidas de uma certa dignidade (TELLES, 2009, p. 116).

Nota-se que, como já observamos antes, a característica que se quer realçar é a de luminosidade trazida pela personagem em meio a um ambiente tão fúnebre, há uma sequência de adjetivos na frase que ressalta tal característica, inclusive com 
proposital exagero. Seguida de adjetivos que demonstram se tratar também de uma pessoa íntegra, apesar vestimentas pobres, mas de caráter e dignidade.

A aura de luz que envolve essa personagem é constantemente retomada no conto, na fala da própria mulher, ao conversar com a narradora sobre a origem de sua fé:

\begin{abstract}
Então sonhei e no sonho Deus me apareceu, quer dizer, senti que ele pegava na minha mão com sua mão de luz. E vi meu menino brincando com o Menino Jesus no jardim do Paraíso. E veio rindo ao meu encontro e me beijou tanto, tanto... Era tal sua alegria que acordei rindo também, com o sol batendo em mim (TELLES, 2009, p. 119).
\end{abstract}

E novamente no final do conto, por meio da observação da narradora "Sob o manto preto, de pontas cruzadas e atiradas para trás, seu rosto resplandecia." (TELLES, 2009, p. 120). Há também a hipótese da própria cidade em que a mulher vive esteja associada à ideia de brilho, de luz. Ela diz viver em Lucena, uma cidade do interior, em latim, o prefixo luc(i) - quer dizer luz, assim como em lúcido, aquele que vê claramente.

Os elementos bíblicos trazidos pelo conto, associados às palavras que contrastam as duas personagens, simbolicamente retratam conflito espiritual em que a narradora se encontra, questionada se acredita em Deus ela responde afirmativamente, mas com um murmúrio, na verdade, ela não sabe em que acredita. Para Micheletti (2012):

O contraste entre as duas mulheres construído no texto: a água quente e verde, pela manhã, prendem-se ao apego à vida, à esperança que a mãe da criança representa; já a noite, a água tão fria, o sulco negro deixado na água pela barca, alia-se à morte, à desesperança. A resplandecência e o brilho de uma contrasta com o silêncio e a escuridão da outra o que acentua a angústia e a solidão da narradora. Desse contraste emerge a necessidade da narradora, sua travessia em busca de paz e equilíbrio interior, corporificadas pela barca, pelo rio e pelo Natal (p. $88-89$ ). 
Podemos observar o contraste entre as duas mulheres, observando as palavras com função caracterizadora que descrevem essas personagens, de modo a corroborar a afirmação de Micheletti.

\begin{tabular}{|l|l|}
\hline Mulher que carrega a criança & \multicolumn{1}{|c|}{ Narradora } \\
\hline \multicolumn{1}{|c|}{ Presença de luz e calor } & \multicolumn{1}{|c|}{ Ausência de luz e calor } \\
\hline Olhos claros & Luz vacilante \\
Olhos brilhantes & Sulco negro \\
Lucena & Escuridão \\
Mão de luz & Sombra \\
Sol & Noite \\
Resplandecia & Treva \\
Manhã & Fria \\
Quente & \\
\hline
\end{tabular}

Podemos notar que as palavras e expressões relacionadas a cada uma das personagens é bem contrastante. Assim como ocorre em Verde lagarto amarelo, temos a clara oposição das duas mulheres, relacionada a seus estados de espírito. Os elementos ligados à narradora explicitam sua falta de fé, seu pessimismo. Há a presença das palavras noite, fria, sombra, que sugerem a escuridão e o isolamento em que se encontra. Em contrapartida, os elementos opostos manhã, quente, sol, mostram que o estado de espírito em que se encontra a outra personagem é exatamente 0 oposto.

A maioria dos elementos relacionados à imagem da mulher que conversa com a narradora são elementos claros, brilhantes. O ambiente lúgubre em que se encontra não consegue apagar-lhe o brilho próprio que conserva consigo. As exceções são os elementos que descrevem suas roupas, deterioradas e escuras. Essa caracterização acaba não contrastando com o restante de sua personalidade, pois é o uso desses itens lexicais que nos permitem fazer a associação dessa personagem com a Virgem Maria, o que reforça o sentimento de esperança e a sugestão do acontecimento de um milagre.

No conto, a narradora busca apagar-se, esconde seus sentimentos e seu passado. Por isso, a maioria das palavras que caracteriza a personagem não faz 
referência a narradora, que possui o ponto de vista da história, mas sim à mulher com a criança de colo, conforme podemos observar no quadro abaixo:

\begin{tabular}{|l|l|}
\hline \multicolumn{2}{|c|}{ Mulher que carrega a criança } \\
\hline \multicolumn{1}{|c|}{ Características físicas } & Imagem da Virgem Maria \\
\hline Jovem & Figura Antiga \\
Pálida & Manto escuro \\
Mãos exaltadas & Manto negro \\
Roupas puídas & \\
Rosto tranquilo & \\
Queixo agudo e altivo & \\
Expressão doce & \\
Olhos vivíssimos & \\
Mãos enérgicas & \\
Olhos claros & \\
Olhos brilhantes & \\
\hline
\end{tabular}

A associação das palavras é maleável para ser formulada e reformulada sob o ponto de vista do leitor. Importante ressaltar, contudo, que os contrastes presentes no conto devem sempre, de um modo ou de outro, estar presentes na formulação dessas associações, sejam elas a representação de vida x morte, esperança $\mathrm{x}$ desesperança, otimismo $\mathrm{x}$ pessimismo, fé $\mathrm{x}$ incredulidade, entre outras tantas relações possíveis.

Para os alunos, devemos ressaltar também que a ausência dos adjetivos relacionados à narradora deve igualmente ser observada. Essa mulher não se descreve explicitamente, mas os substantivos utilizados no conto que sugerem a ausência de luz e a maneira como a narradora/personagem formula a descrição do ambiente a sua volta nos permitem traçar seu perfil psicológico. Se a análise se limitasse a observar somente os adjetivos, não haveria como encontrar as características da personagem de maneira correta.

Ao fazer uma discussão sobre o conto com os estudantes, é importante que eles compreendam que a essência do texto não está em provar se houve um milagre ou se a narradora se confundiu. A essência é justamente deixar o desfecho em aberto, promovendo a hesitação do leitor. $O$ aluno deve perceber que as 
escolhas lexicais permitem que o autor conduza o leitor a determinada interpretação. A descrição da personagem que leva a criança, o uso de palavras caracterizadoras contrastantes entre essa personagem e os elementos do conto, faz com que o leitor seja direcionado a crer que algo fora do comum ocorreu na barca.

Cabe relembrar que em Verde lagarto amarelo o conto termina antes que seja revelado qual o conteúdo da pasta de Eduardo, mas a análise do conto faz com que o leitor seja conduzido a deduzir que se trata de um romance escrito por Eduardo. Algo semelhante ocorre em Natal na barca, em que o leitor fica com a impressão de que o milagre foi testemunhado pela narradora, embora seja mais complicado, nesse caso, fazer uma afirmação mais veemente, por se tratar de um fato sobrenatural.

Nos três contos analisados neste trabalho, percebe-se que Lygia Fagundes Telles aborda a memória humana. Em A Caçada, temos a lembrança embolorada pelo tempo, carcomida pelas traças, que aos poucos vem à tona, vai se tornando mais nítida, assim como a tapeçaria. Quanto mais a personagem recobra as memórias esquecidas, mais intensa se torna a narrativa.

Em Verde Lagarto Amarelo, a memória assombra o protagonista. É o irmão que traz a tona a Rodolfo as lembranças da infância, os flashbacks de Rodolfo são apresentados ao leitor durante toda narrativa, revelando os sentimentos que a personagem sente em relação ao irmão e a si mesmo.

Por último, Natal na Barca apresenta a total negação da memória, é a primeira frase do conto "Não quero nem me lembrar por que me encontrava naquela barca (TELLES, 2009, p.115)." Não sabemos o que tornou a personagem amargurada e pessimista, mas sabemos que existe uma relação do seu comportamento com seu passado, portanto, há resistência em retomar suas lembranças.

Os contos de Lygia Fagundes adentram a psicologia humana, aventurando-se também pelos labirintos da memória. 


\section{CAPÍTULO V - PERSPECTIVAS DIDÁTICAS}

\subsection{O léxico e a estilística no ensino da língua}

Os PCN deixam claro que o eixo do estudo da disciplina de Língua Portuguesa deve ser o texto. Mais do que isso, é a partir desse documento que a noção de gênero do discurso/texto ganha força no âmbito educacional. Bakhtin (1997, p. 280) define os gêneros como "tipos relativamente estáveis de enunciados". A mesma ideia sobre gêneros é encontrada nos PCN que caracterizam os gêneros como "determinados historicamente, constituindo formas relativamente estáveis de enunciados, disponíveis na cultura" (BRASIL, 1998, p. 21). Ainda segundo Bakhtin:

Todas as esferas da atividade humana, por mais variadas que sejam, estão sempre relacionadas com a utilização da língua. Não é de surpreender que o caráter e os modos dessa utilização sejam tão variados como as próprias esferas da atividade humana, o que não contradiz a unidade nacional de uma língua. A utilização da língua efetua-se em forma de enunciados (orais e escritos), concretos e únicos, que emanam dos integrantes duma ou doutra esfera da atividade humana. $O$ enunciado reflete as condições específicas e as finalidades de cada uma dessas esferas, não só por seu conteúdo (temático) e por seu estilo verbal, ou seja, pela seleção operada nos recursos da língua - recursos lexicais, fraseológicos e gramaticais , mas também, e sobretudo, por sua construção composicional. Estes três elementos (conteúdo temático, estilo e construção composicional) fundem-se indissoluvelmente no todo do enunciado, e todos eles são marcados pela especificidade de uma esfera de comunicação (1997, p. 280).

Portanto, ao trabalharmos com os gêneros do discurso/texto devemos levar em conta esses três aspectos: conteúdo temático, o que se diz por meio do gênero; construção composicional, estrutura particular de determinado gênero; e estilo, particularidades e especificidades da linguagem, sobretudo que marcam 0 posicionamento do locutor. 
No desenvolvimento da parte teórica do presente estudo, mostramos que o ensino puramente gramatical é insuficiente para analisar os recursos expressivos da língua. Além disso, a simples classificação taxativa das palavras, nessa ou naquela classe, não dá conta de observar a verdadeira função que determinada palavra exerce em certos contextos.

Bakhtin lecionou em uma escola russa na primeira metade do século XX. Por meio de uma experiência realizada com seus alunos, ele observou a ineficácia das formas gramaticais quando estudadas de forma isolada. Apesar de sua experiência se voltar a um item sintático da língua, sua pesquisa pode trazer alguns pontos de reflexão, uma vez que o autor considera a importância dos aspectos semânticos e estilísticos no ensino da língua, o que nos leva a tomar como base seu exemplo (BAKHTIN, 2013).

A experiência de Bakhtin consistiu em analisar as produções textuais de estudantes da $8^{\mathrm{a}}, 9^{\mathrm{a}}$ e $10^{\mathrm{a}}$ série de uma escola russa (correspondente ao Ensino Médio no sistema educacional brasileiro). Observando essas produções, ele constatou que raramente um período composto por subordinação sem conjunção aparecia na redação dos estudantes.

Segundo o autor, isso ocorria porque não havia sido abordado devidamente 0 significado estilístico dessa forma na $7^{\text {a }}$ série (correspondente ao $9^{\circ}$ ano no sistema educacional brasileiro). Os alunos desconheciam o valor das orações subordinadas sem conjunção, portanto não a utilizavam. Bakhtin propôs para sua classe da $7^{a \underline{a}}$ série a análise estilística de três períodos compostos por subordinação sem conjunção. A título de exemplificação, tomaremos como base um desses períodos:

Triste estou: o amigo comigo não está (Puchkin)

Com base na análise estilística do período, Bakhtin levou seus alunos a perceberem que a construção sintática da forma como foi concebida pelo autor mantém a expressividade, que se perde ao transformar a frase num período composto em que há conjunção, como: Estou triste, porque o amigo não está comigo. Embora as duas formas sejam gramaticalmente corretas, perde-se a expressividade emocional quando se inclui a conjunção, deixando a frase mais fria e lógica. Cria-se um volume excessivo de palavras e uma sonoridade desagradável, 
além da perda da entonação e da capacidade imagética do discurso (BAKHTIN, 2013).

Após o trabalho de análise estilística realizado na $7^{\mathfrak{a}}$ série, Bakhtin pôde observar que houve um aumento substancial na utilização do período composto por subordinação sem conjunção na produção dos alunos. A incidência que se limitava a três casos dentre trezentas redações, passou para mais de setenta casos na $\mathbf{8}^{\underline{a}}$ série. $\mathrm{Na} 10^{\mathrm{a}}$ série ele constatou que ocorreram dois ou três períodos sem conjunção em quase todas as produções.

A experiência realizada por Bakhtin mostra a eficiência da estilística nas aulas de língua; apenas a gramática pura e descontextualizada não faz com que o aluno compreenda o valor de determinadas escolhas linguísticas no lugar de outras. Como dito pelo próprio autor, "As formas gramaticais não podem ser estudadas sem que se leve sempre em conta seu significado estilístico. Quando isolada dos aspectos semânticos e estilísticos da língua, a gramática inevitavelmente degenera em escolasticismo" (BAKHTIN, 2013, p. 23).

O estudo realizado por Bakhtin mostra que é possível escolher uma ou outra forma gramatical - oração com ou sem conjunção - para se conseguir um ou outro efeito de sentido. O estudo de Bakhtin pode contribuir para o ensino do léxico, pois avalia que determinadas escolhas, em um texto, podem ser mais expressivas do que outras. Essa expressividade também se constata na seleção de determinados itens lexicais.

Lapa (1998), referindo-se sobre o emprego do adjetivo, traz o exemplo prático de uma sentença formulada por um de seus alunos. O jovem havia escrito:

No lindo campanário ouvem-se as badaladas que anunciam a missa...

Os mestres chamaram a atenção do discípulo para a palavra lindo, que nada acrescentava àquele contexto, além de dar volume à frase. O aluno escolheu substituir a palavra por vetusto. O item lexical ainda não pareceu ser o mais adequado. Segundo Lapa (1998), vetusto é um termo que recorre ao latim, pouco familiar, portanto muito mais literário. Os mestres julgavam ser mais adequado o uso da palavra velhusco, termo mais corrente, contudo admitiam que a palavra também tivesse usos pejorativos. Dentre as possibilidades de escolhas, foi respeitada a 
preferência do aluno pelo termo vetusto, pois, primeiramente, era uma característica do campanário e, propositalmente, conferia mais dignidade à igreja, já que o autor da frase era católico praticante e estava se referindo à igreja de sua terra.

Esse exemplo mostra como escolher um item lexical no lugar de outro não é tarefa neutra e despretensiosa, como já dissemos. Não basta apenas substituir uma palavra por outra que, supostamente, tenha o mesmo significado. Conforme Monteiro (2009), pode se tratar de uma mesma referência, porém com outros valores evocados. O autor explica:

[...] os componentes afetivos definem a dimensão estilística do significado, além de que, na construção dos enunciados, a decisão por um ou outro lexema depende de uma operação de escolha. E esta é condicionada pelo intuito de estabelecer conotações, que jamais se equivalem nos contextos de uso (MONTEIRO, 2009, p. 102).

Uma escolha lexical também pode ser feita a fim de evitar os vocábulos extensos, como observa Lapa (1998). O autor exemplifica a preferência pelo vocábulo tortuoso no lugar de tortuosidade. No contexto em que foi analisado (fezIhe sentir o tortuoso do seu procedimento), o autor julgou que, sendo a seleção do termo mais condensada, não roubava a energia da imagem e dava mais realce à qualidade. É uma questão de âmbito estilístico, como afirma Monteiro (2009), ele diz "alguns resultados agradam mais pelo ritmo e sonoridade, concentram um maior poder de visualização, excitam a capacidade imaginativa, abrindo um leque de conotações que outros não conseguem estabelecer" (MONTEIRO, 2009, p. 99).

Antunes (2009) também atenta para a escolha de palavras não ser feita de modo aleatório e amplia as questões tratadas aqui para o âmbito da educação, mostrando como os estudos lexicais têm sido negligenciados no ensino da língua. $A$ autora afirma que "a questão do léxico poderia ser vista de forma mais relevante na escola, com base nas funções que ele desempenha e na organização do texto" (ANTUNES, 2009, p. 142).

São raras, no entanto, discussões sobre como o estudo do léxico pode amparar a análise do texto, questão que vai muito além da localização dos significados das palavras. Nos livros didáticos, por exemplo, Antunes (2012, p. 20) 
discute que "o estudo do léxico fica reduzido a um capítulo em que são abordados os processos de 'formação de palavras'”. O mesmo acontece nos planejamentos docentes, em que pouco se trata sobre o ensino lexical.

Os PCN trazem um item destinado ao ensino do léxico, em que explica os objetivos desse ensino, sendo alguns deles:

- inventariar as palavras de determinado campo semântico, presentes em determinado texto, e analisar os efeitos de sentido obtidos com o emprego;

- inventariar as palavras de determinada variedade ou registro, presentes em um texto, e analisar os efeitos obtidos com o emprego;

- identificar, em textos, palavras ou expressões que instalam pressuposições e subentendidos e analisar as implicações discursivas;

- identificar e analisar a funcionalidade de empregos figurados de palavras ou expressões (BRASIL, 1998, p. 84 - 85).

Os PCN indicam que esses procedimentos devem ser incorporados à produção textual, e completam: "Não se trata de estimular o uso de palavras difíceis ou raras, mas de apreciar as escolhas em função da situação interlocutiva e dos efeitos de sentido que se quer produzir" (BRASIL, 1998, p. 85). Por isso, defendemos que não somente esse estudo deve ser incorporado à produção textual, mas também à leitura de textos, sobretudo os textos literários, que costumam requerer bastante da compreensão do leitor.

O trabalho com os recursos estilísticos, o estudo das escolhas lexicais e o estudo gramatical são fundamentais para o auxílio da compreensão textual. Não há motivos para que os aspectos do texto que foram apresentados não sejam inseridos na prática docente, pois essa abordagem só poderá contribuir com a aprendizagem do aluno.

\subsection{A leitura e a compreensão do texto}

É inquestionável que a leitura ainda é uma competência que se tem apresentado bastante falha, prova disso são os sucessivos resultados insatisfatórios 
cujas avaliações como SAEB, ENEM, PISA têm apontado ao longo dos anos. Ao mesmo passo que os números indicam que os alunos das escolas brasileiras apresentam uma educação deficitária no que se refere à leitura, fica cada vez mais claro que é por meio da leitura que podemos exercer nossa cidadania.

Segundo Antunes (2009), ler nos possibilita o acesso à informação, ao acervo cultural. Leitura, portanto, respeita um princípio democrático de que todos têm direito à informação. O sujeito que não lê, não decodifica os sinais gráficos, ou seja, o analfabeto, numa sociedade grafocêntrica e letrada como a nossa, fica privado do conhecimento, da informação, do exercício pleno da cidadania. O sujeito incapaz de compreender o que lê, em diferentes níveis também pode sofrer com a exclusão social.

Antunes (2009) ainda aponta duas outras competências estabelecidas pela leitura: dar acesso às formas particulares e específicas de escrever, e despertar a sensibilidade artística, ou seja, a fruição, atribuída à leitura dos textos literários.

Para tentar compreender a dificuldade dos alunos em relação à leitura, observamos dois estudos realizados em diferentes escolas. O primeiro foi realizado com alunos de Ensino Fundamental por Boruchovich (2001). A autora entrevistou 110 alunos de uma escola municipal de Campinas sobre as suas estratégias de leitura e pôde perceber, primeiramente, que a grande maioria dos alunos entrevistados que dizem não compreender algum texto durante determinada leitura tem consciência disso (92\%). Depois, ao perguntar sobre o que os alunos costumam fazer para ajudá-los a compreender o texto que não estão entendendo, a pesquisadora pôde constatar que houve baixa frequência de respostas que se encaixavam na categoria de estratégias e também não houve grande diversidade das estratégias apresentadas. A estratégia mais citada foi reler o texto $(31,8 \%)$, entretanto pouquíssimos alunos (apenas 1,1\%) citam a busca de algum acessório para o auxílio daquela leitura, como o uso do dicionário, por exemplo, e muitos alunos citam atitudes que demonstram falta de autonomia ou motivação, como apoio social $(44,3 \%)$, ou não fazer nada $(4,5 \%)$.

Boruchovich (2001) também notou que a maior incidência de respostas de alunos que não fazem nada para tentar compreender o texto ou que buscam apoio social sem tentar antes compreender o texto sozinhos é de alunos repetentes. Assim, ela associa a leitura ao bom rendimento escolar e sugere que estudantes que 
tenham dificuldades na leitura dos conteúdos poderiam se beneficiar de um ensino que sistematizasse as estratégias do processo de leitura.

Joly, Santos e Marini (2006) também realizaram um estudo para observar as estratégias de leitura, mas com alunos do Ensino Médio. O grupo de pesquisadoras organizou um questionário e entrevistou 487 alunos sobre suas estratégias metacognitivas antes da leitura, durante a leitura e após a leitura. Essas pesquisadoras compreendem estratégias metacognitivas de leitura como:

consciência que o leitor tem sobre o próprio nível de compreensão durante a leitura e a habilidade para controlar as ações cognitivas, por meio de estratégias que facilitem a compreensão de determinado tipo de texto ou de tarefa determinada (JOLY; SANTOS; MARINI, 2006, p. 206).

Segundo a constatação de Joly, Santos e Marini (2006), o momento após a leitura foi o que apresentou menor recorrência às estratégias metacognitivas de leitura, indicando que os alunos não utilizam materiais de referência para melhor compreensão do texto. $\mathrm{O}$ uso de estratégia de solução de problemas durante a leitura é mais citado, e novamente reler trechos do texto é uma das estratégias que aparece com grande recorrência. Assim como no estudo de Burochovich (2001), esse estudo com alunos do Ensino Médio também chegou à conclusão de que a dificuldade de compreensão textual dos alunos está estritamente ligada ao pouco uso das estratégias de leitura que utilizam. Além disso, Joly, Santos e Marini (2006) apontam que os alunos não o fazem, pois desconhecem o que são, o porquê, quando e como utilizá-las, e que os próprios professores pouco valorizam as práticas de ensinar estratégias de leitura como recurso facilitador da compreensão do texto.

Diante dos dados apresentados, defendemos que estratégias de leitura devem ser de uso consciente na compreensão textual, por isso acreditamos que possibilitar ao aluno a observação das escolhas lexicais por meio dos campos léxico-semânticos e, sobretudo, por meio das palavras que exercem função caracterizadora, pode constituir uma estratégia metacognitiva de leitura, auxiliando na compreensão do texto e ajudando-o a formular ou refutar uma determinada interpretação. 


\subsubsection{Uma proposta de leitura dos contos de Lygia Fagundes Telles em sala de aula}

Com base nas considerações teóricas apresentadas, foi desenvolvida uma proposta que consiste na aplicação de atividades em sala de aula. Cabe ao aluno observar como as palavras com função caracterizadora contribuem para o efeito de sentido do texto.

A proposta foi aplicada com alunos do $9^{\circ}$ ano (idade entre 13 e 15 anos) de uma escola municipal de Ensino Fundamental I e II, localizada na cidade de São Caetano do Sul.

Foi escolhida uma sala com 24 alunos, que, segundo relato dos professores, apresentava bastante dificuldade na interpretação textual. Os três textos literários do gênero conto, de autoria da escritora Lygia Fagundes Telles foram utilizados na sequência didática, a fim de colaborar com a ampliação da capacidade leitora desses alunos.

A proposta objetivou explorar uma estratégia de ensino que pudesse, por meio da análise do léxico e seus efeitos expressivos, contribuir com a aprendizagem dos alunos na compreensão textual, sobretudo do texto literário.

$\mathrm{Na}$ elaboração dessa sequência houve dois desafios: primeiro, propor uma atividade que auxiliasse $o$ aluno na interpretação dos contos, sem, contudo, tirar-Ihe o prazer estético que o gênero pode transmitir; segundo, também buscar atenuar um pouco da dificuldade que os alunos apresentam ao ler um texto em sala de aula.

Além da observação dos campos léxico-semânticos, para guiar as atividades de leitura, utilizou-se como referencial teórico o estudo de Rojo (2004), que descreve os procedimentos, as estratégias e as capacidades de leitura, com algumas adaptações, para formular a sequência didática.

Cabe ressaltar que as atividades que constam da proposta nortearam o presente estudo para apresentação e discussão dos resultados, entretanto, com base no referencial teórico e nos objetivos propostos, outras atividades poderiam ser formuladas.

Antes de realizar as atividades de leitura, iniciou-se com uma atividade que consta no livro Oficina de Gramática, escrito por Kleiman e Sepulveda (2012). Para 
ampliar as possibilidades de caracterização, os alunos deveriam encontrar o maior número de adjetivos possíveis para descrever dois objetos. Os vocábulos sugeridos no livro eram maçã e cama. Foram selecionadas duas palavras que aparecem nos contos lidos posteriormente para a realização da atividade (bosque e uva). Assim, os alunos deveriam descrever esses objetos, com palavras relacionadas aos cinco sentidos, organizando essas palavras em uma tabela. Conforme o exemplo que segue:

\begin{tabular}{|c|c|c|c|c|}
\hline \multicolumn{3}{|c|}{ Bosque $^{9}$} \\
\hline Paladar & Visão & Tato & Olfato & Audição \\
\hline & & & & \\
\hline & & & & \\
\hline & & & & \\
\hline
\end{tabular}

\begin{tabular}{|l|l|l|l|l|}
\hline \multicolumn{5}{|c|}{ Uva $^{10}$} \\
\hline Paladar & Visão & Tato & Olfato & Audição \\
\hline & & & & \\
\hline & & & & \\
\hline & & & & \\
\hline
\end{tabular}

Ao pensar em palavras que caracterizam o bosque, a partir de elementos sensoriais, os alunos são levados a imaginar-se dentro de uma floresta. Precisam transportar-se para aquele ambiente para conseguir descrever o que há nele. Essa é a mesma sensação que é experimentada com o conto $A$ caçada. O papel do aluno é fazer essa relação após a leitura do conto.

Já a palavra uva foi selecionada pelo simbolismo que mantém na caracterização de uma das personagens do conto Verde Lagarto Amarelo, o irmão mais novo Eduardo. Nesse momento, os alunos podem observar vários adjetivos que são atribuídos à fruta. No momento da leitura do conto, devem perceber como

\footnotetext{
${ }^{9}$ Vocábulo presente no conto $A$ caçada

${ }^{10}$ Vocábulo presente no conto Verde Lagarto Amarelo
} 
essas características são transferidas para Eduardo, como, por exemplo, a cor de violeta dos olhos.

Além da relação com os contos, pretendeu-se com a escolha desses vocábulos que os alunos pudessem usar características que se relacionassem a todos os sentidos. Portanto, se a palavra bosque pouco permitiu que o sentido do paladar fosse explorado para adjetivação, a palavra uva supriu a necessidade de explorar as características referentes ao paladar.

O uso do dicionário foi recomendado em todas as atividades propostas. Foram utilizados os dicionários impressos, nos quais se buscaram sinônimos para um adjetivo que já foi escrito na tabela e até mesmo para o próprio vocábulo a ser caracterizado. Com esse auxílio, é esperado que os alunos utilizem características para bosque como: escuro, sombrio, lúgubre, obscuro, iluminado, claro, verde (visão); úmido, molhado, orvalhado, áspero, lamacento (tato); cheiro de mato, cheiro de terra (olfato); silencioso, tácito, quieto, barulhento, ruidoso (audição). A acepção da palavra uva já traz algumas características que os estudantes podem utilizar (fruta ovóide ou elipsóide, verde, rosada, rubra, azulada ou preta, doce, mais ou menos ácida, comestível). Esperam-se também características, como, por exemplo: saborosa, suculenta, sumarenta, doce, ácida (paladar); roxa, violeta, brilhante, reluzente, esférica, redonda, pequena, delicada (visão); aveludada, lisa, pegajosa (tato); adocicada, azeda (olfato).

Uma vez que os alunos ampliem seu léxico individual e tenham clara a função da adjetivação, é possível dar continuidade à sequência, iniciando a leitura do conto.

O primeiro conto lido é o conto $A$ caçada. Os objetivos específicos dessa atividade são:

$\checkmark$ Observar as características sensoriais no conto e como elas criam a atmosfera que transporta o leitor para junto da personagem;

$\checkmark$ Ampliar o conceito de palavra que tem a função caracterizadora, elencando adjetivos, substantivos e verbos que imprimem características às personagens e ao ambiente no conto;

$\checkmark$ Observar o uso do adjetivo anteposto como recurso estilístico;

$\checkmark$ Compreender que a seleção lexical das palavras com função caracterizadora no conto remete à oposição caça x caçador, avaliar essa implicação para os sentidos do texto. 
Algumas das capacidades de compreensão citadas por Rojo (2004) são: ativação de conhecimentos de mundo; antecipação ou predição de conteúdos ou propriedades do texto; e checagem de hipóteses. Ao selecionar uma palavra do conto $A$ caçada para realizar a primeira atividade, foi possível fazer com que os alunos ativassem seus conhecimentos prévios. Para fazer a antecipação do conteúdo do conto, propôs-se uma discussão com a sala sobre o título do conto com a seguinte pergunta: "O que esperam ler no conto que se intitula A caçada?". Após a leitura silenciosa realizada pelo aluno, ele pode avaliar se o que inferiu a partir do título se confirma ou não. Segundo Rojo:

\footnotetext{
Ao longo da leitura, no entanto, o leitor estará checando constantemente essas suas hipóteses, isto é, confirmando-as ou desconfirmando-as e, consequentemente, buscando novas hipóteses mais adequadas. Se assim não fosse, o leitor iria por um caminho e o texto por outro (2004, p. 05).
}

Por ser o primeiro conto lido da autora optou-se por deixar para discutir sobre o seu estilo depois da leitura a partir das observações dos alunos. Dessa forma, eles não foram privados do efeito surpresa do desfecho.

Em seguida, foi solicitado aos alunos responderem em grupos as seguintes questões:

1) Logo no início do conto, a loja de antiguidades é descrita pelo narrador. Como é descrita essa loja?

2) Que sentidos (visão, paladar, tato, olfato, audição) são explorados nessa descrição? Que efeito esse tipo de descrição transmite ao leitor?

3) Quando um escritor quer dar ênfase a uma característica de uma personagem ou de um objeto, por exemplo, um recurso que ele pode utilizar é colocar o adjetivo antes do substantivo, dando destaque para aquela característica. Vamos observar um dos parágrafos do conto $A$ caçada: 
(§19) Era uma caçada. No primeiro plano, estava o caçador de arco retesado, apontando para uma touceira espessa. Num plano mais profundo, o segundo caçador espreitava por entre as árvores do bosque, mas esta era apenas uma vaga silhueta, cujo rosto se reduzira a um esmaecido contorno. Poderoso, absoluto era o primeiro caçador, a barba violenta como um bolo de serpentes, os músculos tensos, à espera de que a caça levantasse para desferir-Ihe a seta.

a) Em que momento os adjetivos precedem os substantivos?

b) Que efeito de sentido é obtido com o uso dos adjetivos nessa posição?

4) Ao longo da leitura do conto, somos transportados ao ambiente da loja de antiguidades, e, pouco a pouco, também para dentro da tapeçaria, como se vivenciássemos a mesma experiência do narrador. Isso se deve à habilidade com que o texto foi construído, imprimindo no leitor o máximo de imagens, sensações e sentimentos. Ao observarmos atentamente as palavras que nos fazem perceber características do ambiente, dos caçadores, da tapeçaria e da personagem principal, podemos verificar que além dos adjetivos, os substantivos e os verbos, embora não possuam gramaticalmente essa função, ajudam a descobrir importantes características desses elementos.

$\mathrm{O}$ quadro a seguir pode ser preenchido de acordo com as palavras que julgar ter função caracterizadora no conto $A$ caçada.

\begin{tabular}{|l|c|c|}
\hline Adjetivos & $\begin{array}{c}\text { Substantivos } \\
\text { (com função } \\
\text { caracterizadora) }\end{array}$ & $\begin{array}{c}\text { Verbos } \\
\text { (com função } \\
\text { caracterizadora) }\end{array}$ \\
\hline & & \\
& & \\
\hline
\end{tabular}

Após o preenchimento do quadro, procedeu-se a uma roda de conversa para ouvir quais impressões os alunos tiveram do conto e o que eles conseguiram inferir por meio daquelas características que escreveram. Cabe aos alunos observarem 
que aquelas palavras são escolhidas para contribuir com o sentido que se dá ao texto. É esperado que passem a observar as palavras que exercem função caracterizadora no texto, pois essa pode ser uma estratégia de compreensão.

O segundo texto lido é o conto Verde Lagarto Amarelo. Por se tratar da continuidade da sequência didática, antes da apreciação da leitura pode-se discutir o estilo de Lygia Fagundes Telles, cuja temática apesar de aparentar ser simples, mergulha na interioridade humana, explorando suas emoções, mesmo aquelas que, de acordo com a convenção social, devemos manter bem escondidas. Essas considerações são importantes para a próxima leitura. A leitura desse conto é considerada mais complexa do que a primeira; o texto é mais extenso e há diversas quebras cronológicas devido às divagações de Rodolfo, que constantemente resgata as lembranças da infância, por conta da presença do irmão. Por isso, a leitura deve ser feita junto com os alunos. Com a leitura de Verde Lagarto Amarelo objetiva-se:

$\checkmark$ Observar as palavras que exprimem um julgamento/ avaliação;

$\checkmark$ Analisar como a representação dos dois irmãos leva o conto a explorar o sentimento da inveja;

Sugere-se que antes da discussão os alunos façam suas atividades por escrito, conforme segue:

1) De acordo com a leitura do conto, monte um quadro com as características que descrevem os dois irmãos.

\begin{tabular}{|l|l|}
\hline Rodolfo & Eduardo \\
\hline & \\
& \\
& \\
\hline
\end{tabular}

2) Que personagem possui mais características que expressam uma avaliação negativa? Procure dar exemplos e explicar por que essa palavra é considerada negativa. 
3) Observando o quadro do primeiro exercício, e sabendo que o foco narrativo do conto é em 1a pessoa (narrado por Rodolfo), qual a conclusão que podemos tirar sobre Rodolfo e sua autoimagem?

4) Que sentimentos Rodolfo parece ter em relação a seu irmão Eduardo?

A atividade é concluída novamente com uma roda de conversa sobre a leitura e a atividade realizada. Depois, aponta-se aos alunos que novamente eles realizaram a mesma estratégia de leitura já feita no conto $A$ caçada. Eles observaram as palavras com função caracterizadora para tentar compreender melhor o texto e depois buscar uma interpretação.

A última atividade se pauta na análise do conto Natal na Barca. Dessa vez os alunos devem criar, em grupos, seus próprios campos léxico-semânticos, para depois desenvolver um parágrafo explicando a composição desses campos. A partir dessa atividade, procurou-se verificar como os alunos interpretaram o conto, quais foram as pistas linguísticas que as escolhas lexicais apresentadas no texto forneceram e se essas pistas foram percebidas pelos alunos. Também objetivou-se avaliar como essa atividade pode contribuir com o entendimento do conto.

A partir de todas as atividades realizadas, foi desenvolvida a análise dos resultados.

\subsubsection{Resultados e discussão}

Foram necessárias sete aulas (50 minutos) para que a sequência didática fosse concluída. A primeira atividade foi realizada em uma aula. Os alunos realizaram, em grupos de quatro estudantes, o preenchimento da tabela com as características dos vocábulos bosque e uva. Todos os grupos concluíram a primeira atividade com êxito. Houve variedade dos adjetivos utilizados em alguns itens, como na descrição tátil da palavra uva que apresentou as características: dura, mole, macia, frágil, leve, delicada, fria, molhada, lisa. Há também adjetivos diversos em relação ao paladar, contudo a característica doce foi escrita por todos os grupos. Outros adjetivos utilizados foram: azeda, adocicada, gostosa, saborosa, gelatinosa, 
amarga, entre outros. Notamos a recorrência de alguns adjetivos em todas as atividades, como a cor do bosque, verde, e da uva, roxa.

Também foi possível observar que o uso do dicionário foi imprescindível para realizar tais descrições, foi possível notar que os alunos procuraram na acepção da característica pensada em primeiro momento outros termos que pudessem ser utilizados. Na descrição auditiva sobre a palavra bosque encontramos o uso de barulhento, muitas vezes seguido do adjetivo ruidoso, assim como o antônimo silencioso. A utilização do dicionário, portanto, permitiu que os alunos ampliassem seu vocabulário.

Entre os adjetivos e expressões mais recorrentes utilizados pelos alunos, temos o seguinte resultado:

\begin{tabular}{|c|c|}
\hline \multicolumn{1}{|c|}{ BOSQUE } \\
\hline Visão & $\begin{array}{r}\text { verde, esverdeado, grande, bonito, } \\
\text { espaçoso. }\end{array}$ \\
\hline Audição & barulhento, ruidoso, silencioso, calmo. \\
\hline Tato & áspero, molhado, úmido, seco. \\
\hline Olfato & aromático, perfumado, cheiroso, \\
& amadeirado, cheiro de planta.
\end{tabular}

\begin{tabular}{|c|c|} 
& UVA \\
\hline Visão & roxa, pequena, oval, redonda, verde. \\
\hline Audição & \\
\hline
\end{tabular}




\begin{tabular}{|c|c|}
\hline Tato & $\begin{array}{c}\text { fria, molhada, lisa, mole, macia, dura, } \\
\text { madura. }\end{array}$ \\
\hline Olfato & adocicada, cheirosa, enjoativa, agradável. \\
\hline Paladar & doce, azeda, gostosa, saborosa. \\
\hline
\end{tabular}

A maior dificuldade encontrada nessa atividade foi separar o que representava um nome e o que representava uma característica. Como ainda não havíamos abordado a questão dos substantivos que poderiam ser caracterizadores, pedimos que os alunos se concentrassem apenas nos adjetivos. Para fazer a descrição, eles deveriam se imaginar em um bosque, ou manuseando e provando as uvas, por isso, muitos alunos no início da atividade perguntavam se poderiam utilizar em sua descrição palavras como árvore ou pedra. Buscamos orientar os alunos a procurar adjetivos correspondentes aos objetos imaginados na cena. A maior parte foi bem sucedida na tarefa, utilizando unidades lexicais como arborizado, contudo uma das atividades ainda apresentou mata como resposta à descrição visual do bosque.

Aproveitamos essa confusão para mostrar como os substantivos também podem ser elencados na interpretação textual quando estamos estabelecendo um efeito de sentido entre a descrição e o enredo, visto que os substantivos também nos auxiliam a criar uma imagem da cena ou do personagem. A sistematização dos conceitos gramaticais, entretanto, mostrou-se a maior dificuldade apresentada pelos alunos e interferiu na compreensão do conto $A$ caçada, segunda etapa da sequência didática aplicada.

Os alunos realizaram a segunda parte da sequência em duas aulas. Após levantarem hipóteses sobre o título, foi feita a leitura silenciosa do conto e, em seguida, os alunos comentaram sobre suas primeiras impressões sobre o texto. Observaram que suas hipóteses não foram confirmadas, pois imaginaram um texto mais dinâmico, que relatasse uma caçada de fato, e o conto se mostrou mais estático, por descrever a imagem de uma tapeçaria. Em seguida dividiram-se em seis grupos, com quatro integrantes, para realização da atividade escrita. 
A realização da atividade sobre o conto pôde auxiliar os educandos a compreender alguns pontos do texto. Com as primeiras duas questões, os discentes conseguiram estabelecer uma relação com a primeira atividade e perceberam que os elementos descritivos sensoriais transportavam o leitor para dentro do conto. Como podemos observar em algumas respostas da segunda questão:

Que sentidos (visão, paladar, tato, olfato, audição) são explorados nessa descrição? Que efeito esse tipo de descrição transmite ao leitor?

"São exploradas as sensações de visão, tato e olfato, as mesmas sensações são transmitidas ao leitor."

"Olfato, tato e visão. Permite que o leitor se aprofunde na história."

"Olfato e visão são os sentidos explorados na descrição. Traz o efeito de estar naquele local."

"Olfato e visão, transmite um efeito de realidade."

Dois grupos não explicaram quais efeitos eram transmitidos pela descrição, apenas apontaram os sentidos que foram explorados no trecho que descrevia a loja de antiguidades.

As duas últimas questões da atividade foram um obstáculo para os alunos, novamente por conta da análise gramatical. Na terceira questão, em que os alunos deveriam encontrar os adjetivos no excerto transcrito do conto, muitos se sentiram inseguros, confundiram novamente substantivos e adjetivos, ou não conseguiram perceber a que nome o adjetivo fazia referência. Quando questionados, os alunos sabiam reproduzir o conceito do adjetivo: "é a palavra que dá características aos seres/ substantivos, porém não sabiam como aplicar o conceito na análise textual. Essas foram as causas que dificultaram a identificação dos adjetivos antepostos.

Quatro grupos apresentaram respostas satisfatórias quanto à localização dos adjetivos antepostos. $\mathrm{O}$ enunciado da questão já trazia uma justificativa para o uso 
estilístico do adjetivo precedendo o substantivo, mas apenas dois grupos justificaram essa escolha com êxito.

Se a confusão gramatical já havia se mostrado presente na terceira questão, que analisava um trecho do texto, na quarta questão houve uma confusão generalizada. Todos os grupos cometeram deslizes ao classificar gramaticalmente uma ou outra palavra. Contudo, o grande problema ocorreu na observação dos verbos. Os grupos tenderam a selecionar qualquer tipo de verbo presente no texto, sem observar se ele conferia ou não uma característica a algo. Talvez essa solicitação tenha sido precipitada, seria necessário fazer uma análise conjunta antes, para que depois os alunos conseguissem observar a diferença.

Esses apontamentos foram discutidos com os alunos durante a roda de conversa. Tomamos como base uma atividade de um dos grupos e, a partir disso, conversamos sobre a expressividade daqueles lexemas. Também mostramos porque um verbo como murmurar pode ser caracterizador, enquanto que um verbo como ter não teria a mesma carga semântica, pois este não carrega em si uma característica, inclusive funciona, muitas vezes, como verbo auxiliar; enquanto aquele já indica o tom de voz utilizado, a insegurança da personagem.

Antes de aplicarmos a terceira atividade, fizemos uma roda de conversa para discutir sobre as relações familiares. Perguntamos aos alunos se eles tinham irmãos/ irmãs, se eram mais velhos ou mais novos, como era a relação entre eles, se tinham ciúmes deles, ou se já chegaram a pensar um dia se existia um "filho predileto". Foram muitas as considerações feitas pelos alunos, a maior parte acreditando ser o irmão a pessoa mais beneficiada no cotidiano familiar.

A partir dessas considerações discutimos um pouco do estilo de Lygia Fagundes Telles, retomando características do conto $A$ caçada, como o efeito ambíguo criado no desfecho do conto, e também apresentando o próximo conto a ser lido Verde lagarto amarelo, mostrando como a autora aborda as questões dos sentimentos humanos mais profundos, como aqueles que eles haviam descrito durante a conversa inicial.

O conto foi lido pelo professor; os alunos tinham cópias do texto e acompanharam a leitura. A disposição dos estudantes em círculo foi mantida, em meio às considerações dos alunos sobre o conto, conduzimos os alunos a pensar nas questões que propomos sobre o texto. Foi feito um quadro na lousa para 
observar as características das personagens, Rodolfo e Eduardo. Como a atividade não exigia, a princípio, destacar a classe gramatical de cada palavra, os alunos sentiram-se mais livres para eleger as palavras com função caracterizadora dentro do conto. Dessa forma, pôde-se fazer o inverso da atividade anterior. Com base nas palavras selecionadas observamos a classe gramatical a que cada uma pertencia, e chegou-se á conclusão de que substantivos também podem ser caracterizadores em determinados contextos, assim como os verbos. O verbo engordar, por exemplo, foi facilmente identificado pelos alunos como uma palavra caracterizadora.

Após a observação das características e a constatação de que os adjetivos que figuravam na descrição de Rodolfo expressavam, em sua maioria, uma avaliação negativa, não houve problemas para responder as demais questões acerca do conto. Isso mostra que a inversão das questões também fez diferença na compreensão do texto. Verde lagarto amarelo foi por nós considerado um conto mais complexo, entretanto, os discentes conseguiram estabelecer os sentidos desse conto mais facilmente do que com a leitura do conto $A$ caçada, em parte porque estabeleceram um sentido com suas próprias relações pessoais e em parte porque a observação das escolhas lexicais das palavras com função caracterizadora foi realizada antes das demais questões.

Dessa forma, os alunos conseguiram compreender que a observação das características, seja de um ambiente, seja de uma personagem, constitui uma estratégia de leitura. Há intencionalidade do autor na seleção dos vocábulos que organizam a descrição, portanto, os elementos descritivos não são preenchidos aleatoriamente, eles convergem para o efeito de sentido pretendido, que deve ser percebido pelo leitor. Isso também significa que algumas unidades lexicais são selecionadas por seu valor expressivo, de acordo com o estilo do autor, como o caso da palavra felino, utilizada em Verde lagarto amarelo, que remete a significados diversos, com diferente valoração, inclusive, ora no polo positivo, ora no polo negativo.

A última atividade foi a compreensão do conto Natal na barca. Esse conto foi escolhido para ser o último da sequência didática porque trazia elementos de estilo já abordados em cada um dos contos anteriores: o desfecho ambíguo e a caracterização de duas personagens com elementos opostos. 
Os alunos deveriam montar um campo léxico-semântico (como o que foi construído na leitura do conto anterior), confrontando as características de duas personagens: a mulher que viajava sozinha e a mulher que trazia a criança. A partir do campo elaborado, deveriam discorrer sobre o que o conto revelava acerca de cada uma das mulheres.

Os resultados foram bastante significativos, dos 24 alunos que participaram do estudo, 16 apresentaram resultado satisfatório. Os campos elaborados foram bem diversificados, mas os alunos conseguiram perceber a presença, além dos adjetivos, de substantivos que eram importantes na caracterização, como silêncio, treva e solidão.

Alguns alunos estabeleceram uma relação entre o Natal, um milagre de Natal e a figura da Virgem Maria, principalmente pela característica dos olhos, do manto e da fé que tinha a mulher com a criança.

A maior parte foi capaz de observar os elementos de contraste da caracterização. Foi dada mais ênfase à personagem que trazia o bebê, talvez porque as palavras que exercem função caracterizadora aparecem em maior quantidade em relação a essa personagem. As características físicas da personagem foram citadas em todas as atividades. Nas atividades consideradas satisfatórias, essas características foram relacionadas ao otimismo da mulher. Apesar das vestimentas pobres, era uma mulher que tinha fé e esperança, segundo os alunos, o que também justifica, na visão dos discentes, ela ter sido gratificada com o milagre.

Foi interessante observar como os alunos organizaram sua linha de raciocínio, apesar de o conto trazer um final aberto. Não podemos dizer certamente o que ocorreu com a criança que parecia estar morta, mas os alunos tenderam a considerar que ocorreu um milagre. A diferença é que após compreender a função das escolhas lexicais, eles conseguiram criar argumentos, por meio das pistas linguísticas, que comprovavam a sua opinião.

Consideramos que a sequência aplicada foi bastante satisfatória e que a estratégia de leitura trabalhada com os alunos pode servir para compreensão de vários outros textos literários, sobretudo quando ingressarem no Ensino Médio. 


\section{CONSIDERAÇÕES FINAIS}

Conforme mencionamos no início deste trabalho, o ensino da língua tem passado por transformações constantes e as escolas brasileiras têm buscado se adaptar às exigências do mundo contemporâneo. Frequentemente, tem-se discutido e refletido sobre abordagens de ensino mais eficazes, que possam fazer com que 0 aluno expanda seu conhecimento no âmbito escolar e continue a aplicá-lo além dos muros da escola. Muitos esforços têm sido feitos para romper com o ensino da língua portuguesa tradicionalista, mecânico, pautado em regras gramaticais, e temse buscado com bastante empenho promover um ensino, de fato, contextualizado.

O que podemos observar é que a tarefa ainda é bastante complexa. Ao final do Ensino Fundamental II, o aluno deveria mostrar que já consegue fazer a compreensão de textos sem necessitar somente da voz do professor como auxílio. O aluno que está no processo de conclusão desse ciclo escolar deveria ser capaz de traçar estratégias de leitura que Ihe conferisse mais autonomia, sintetizar as ideias de um parágrafo, inferir o sentido de uma expressão, fazer uso de um dicionário, ou observar escolhas lexicais e seus efeitos de sentido, como sugere a proposta de ensino apresentada no presente estudo.

Apesar do empenho empregado para atingir melhor qualidade no ensino da língua, percebe-se, nitidamente, que muitos alunos ainda têm sido expostos ao ensino gramatical que busca apenas ilustrar a norma. $O$ texto não é o principal objeto de análise, nesse caso, ele é apenas o meio pelo qual serão exemplificados os conceitos gramaticais. O resultado dessa metodologia, que forma o aluno reprodutor de nomenclaturas, pôde ser observado durante a aplicação da sequência didática proposta neste estudo. Ele conhece os conceitos, sabe quais as definições de determinados itens gramáticas, entretanto, não vê como pode ser feita sua aplicação prática.

Quando o texto deixa de ser o meio para aprender conteúdos gramaticais e torna-se a finalidade, o foco do ensino/aprendizado; a tarefa, para o aluno, é mais significativa e, não somente, é também mais eficaz. Essa inversão do foco é o que se tem buscado, durante anos, ser implantada de forma consistente na sala de aula. Durante a realização da pesquisa, foi possível perceber como a falta da associação 
do texto à gramática torna irrelevante, para o aluno, resgatar a aprendizagem da estrutura da língua no momento da compreensão textual.

Contudo, conseguiu-se verificar que reverter a atual situação é bastante viável. O texto literário foi trabalhado, com os alunos, para compreensão em três momentos da pesquisa. A cada etapa da sequência didática, os discentes apresentaram resultados mais satisfatórios. Conforme realizavam o exercício de aplicar o conhecimento gramatical ao texto, iam se aprimorando na tarefa, criando mais habilidade, percebendo o valor da proposta para a análise textual. Se com a leitura de apenas três contos em sala de aula, já foi possível registrar índices de melhoria na compreensão textual, acreditamos que a prática constante poderia formar um leitor mais proficiente.

Constatou-se também que a abordagem lexical no ensino da língua ainda é bastante deficitária. O número de atividades que exploram a compreensão do texto por meio da observação das escolhas lexicais é extremamente reduzido. Podemos encontrar nos livros didáticos um ou outro exercício que explora a linguagem do texto, que pede para o aluno refletir sobre os efeitos de sentido produzidos por certo grupo de palavras, mas, ainda, vê-se que dificilmente esse é o enfoque dado pelo professor.

O léxico raramente está sob os holofotes nos livros didáticos, nos planejamentos e na prática docente. Os resultados da presente pesquisa indicam que isso pode ser uma das falhas do ensino brasileiro, que colocam o estudo do vocabulário do texto, com viés semântico e estilístico, numa posição marginal no procedimento de leitura, o que não deveria ocorrer, pois as unidades lexicais são elementos centrais para compreensão textual.

É por meio da observação das escolhas lexicais que o aluno pode desvendar se há uma intencionalidade do autor, se o uso dessas palavras confere mais expressividade ao texto, se o uso dessas palavras indica o estilo individual de um autor. É através dessas pistas linguísticas que o educando pode observar a construção de uma personagem, ou mesmo reproduzir a imagem de um ambiente. Tal observação faz com que o discente produza significados para o texto, deixando de depender, única e exclusivamente, da análise feita pelo professor. É preciso dar subsídios para que o aluno interprete um texto. O aluno que entende o que lê passa 
a gostar da leitura e pode tornar essa atividade mais frequente, inclusive fora da sala de aula.

Outra questão a ser observada diz respeito às respostas reduzidas apresentadas pelos alunos. Conseguimos perceber nas respostas escritas que, mesmo sabendo responder à questão, os alunos tendem a ser minimalistas, escrevem o mínimo possível ao que foi solicitado. Talvez com a frequência do trabalho com o léxico expandida, os alunos conseguissem desenvolver com mais consistência seus argumentos.

Não deixar claro quais são as estratégias que os discentes dispõem para interpretar um texto é outra falha no ensino. Solicita-se ao aluno que faça a compreensão textual, mas não se ensina como. Como mencionamos no desenvolvimento do presente estudo, estratégias de leitura devem ser de uso consciente. Pôde-se verificar que ao ter conhecimento do procedimento que iriam realizar durante a interpretação do conto, a atenção dos alunos foi redobrada, uma vez que havia um foco de análise durante a segunda leitura realizada e um direcionamento estabelecido.

Os contos de Lygia Fagundes Telles foram de grande valia para realização da pesquisa. O uso da linguagem mais contemporânea permitiu que os alunos fizessem uma leitura fluida do texto. O vocabulário utilizado pela autora foi essencial para que os alunos construíssem seu ponto de vista sobre os sentidos do conto. Lygia Fagundes Telles é bastante perspicaz em suas escolhas, o que contribuiu para aumentar a percepção dos alunos. Contudo, é importante ressaltar que a intenção do presente estudo é que os alunos possam aplicar a mesma estratégia utilizada em diferentes textos, sobretudo em textos literários, o que acreditamos, a partir dos resultados obtidos, ser bastante possível.

Foi interessante verificar também como a observação da relação semântica das palavras possibilitou a ampliação do léxico individual dos educandos. Ao listar palavras pertencentes a um mesmo campo léxico-semântico, os alunos puderam, por meio de inferências (o que ocorreu com maior frequência) ou consulta ao dicionário, expandir seu conhecimento lexical.

A partir dos resultados do presente estudo, podemos concluir que uma estratégia de leitura consciente que vise observar as escolhas lexicais da caracterização do ambiente e das personagens no texto literário é bastante 
significativa para compreensão textual. Em curto prazo, foi possível notar evolução, tanto na autonomia quanto no nível de entendimento dos alunos que participaram da pesquisa. Acreditamos que se tal estratégia fosse adotada desde $\circ 6^{\circ}$ ano do Ensino Fundamental II, com gêneros textuais adequados a cada segmento, os alunos poderiam se habituar a realizar esse tipo de análise. Essa ação aumentaria a frequência do trabalho com o léxico, contribuindo, segundo nossa análise, para melhorar o nível de proficiência de leitura dos estudantes brasileiros. 


\section{REFERÊNCIAS}

ANTUNES, Irandé. Língua, texto e ensino - outra escola possível. São Paulo: Parábola, 2009.

ANTUNES, Irandé. Território das palavras: estudo do léxico em sala de aula. São Paulo: Parábola, 2012.

BAKHTIN, Mikhail. Estética da criação verbal. São Paulo: Martins Fontes, 1997.

BAKHTIN, Mikhail. Questões de estilística no ensino da língua. São Paulo: Editora 34, 2013.

BALLY, Charles. El lenguaje y la vida. Buenos Aires: Losada, 1941.

BECHARA, Evanildo. Moderna gramática portuguesa. Rio de Janeiro: Nova Fronteira, 2009.

BRASIL. Secretaria de Educação Fundamental. Parâmetros curriculares nacionais: terceiro e quarto ciclos do ensino fundamental: língua portuguesa/ Secretaria de Educação Fundamental. Brasília: MEC/SEF, 1998.

BORUCHOVITCH, Evely. Algumas estratégias de compreensão em leitura de alunos do ensino fundamental. Psicologia Escolar e Educacional, v.5, n.1, 19-25, 2001.

CARDOSO, Elis. Escolhas lexicais: a caracterização de personagens femininas no discurso. Linha d'Água, n. 26 (1), p. 15-28, 2013. Disponível em http://www.revistas.usp.br/linhadagua/article/view/55324. Acesso em 31 ago. 2013.

CARDOSO, Elis; IGNEZ, Alessandra. Escolhas lexicais: estilo e expressividade. In: MICHELETTI, Guaraciaba (org.). Estudos de discurso e Estilo. São Paulo: Terracota, 2012.

CÂMARA Jr., J. Mattoso. Estrutura da língua portuguesa. Petrópolis: Vozes, 1970.

CÂMARA Jr., J. Mattoso. Contribuições a estilística portuguesa. Rio de Janeiro: Ao livro técnico, 1978.

CASTILHO, Ataliba T. de. Nova gramática do português brasileiro. São Paulo: Contexto, 2012.

CEREJA, William Roberto; MAGALHÃES, Thereza Cochar. Português: linguagens, $9^{\circ}$ ano: língua portuguesa. São Paulo: Saraiva 2012.

CORTÁZAR, Julio. Valise de Cronópio. CIDADE: Perspectiva, 2013. 
CUNHA, Antônio Geraldo. Dicionário etimológico Nova Fronteira da língua portuguesa. Rio de Janeiro: Nova Fronteira, 1986.

CUNHA, Celso; CINTRA, Lindley. Nova gramática do português contemporâneo. Rio de Janeiro: Lexikon, 2013.

DELMANTO, Dileta; CARVALHO, Laiz B. Jornadas.port - Língua Portuguesa, 9 ano. São Paulo: Saraiva, 2012.

DIMAS, Antonio. Garras de Veludo - Posfácio. In: TELLES, Lygia Fagundes. Antes do baile verde. São Paulo: Companhia das Letras, 2009.

ENKIVIST, Nils Erik. Definindo o estilo. In: SPENCER, John (org.). Linguística e estilo. São Paulo: Cultrix e Editora da Universidade de São Paulo, 1974.

GENOUVRIER, Emile; PEYTARD, Jean. Linguística e Ensino do Português. Coimbra: Livraria Almedina, 1974.

GERALDI, João Wanderley (org). O texto na sala de aula: leitura e produção. Cascavel: Assoeste, 1984.

GOTLIB, Nádia Battella. Teoria do Conto. São Paulo: Ática, 2002.

GRILLO, Sheila; VÓLKOVA AMÉRICO, Ekaterina. Bakhtin, Vinográdov e a estilística. In: BAKHTIN, M. Mikhail. Questões de estilística no ensino da língua. São Paulo: Editora 34, 2013.

HENRIQUES, Claudio Cezar. Léxico e semântica: estudos produtivos sobre palavra e significação. Rio de Janeiro: Elsevier, 2011.

INSTITUTO NACIONAL DE ESTUDOS E PESQUISAS EDUCACIONAIS ANÍSIO TEIXEIRA. Programa Nacional de Avaliação de Alunos (PISA): resultados nacionais - PISA 2009. Brasília: O instituto, 2012. Disponível em $<$ http://download.inep.gov.br/acoes internacionais/pisa/documentos/2012/relatorio nacional pisa 2009.pdf.> Acesso em 15 set. 2013.

JOLY, Maria Cristina R. A.; SANTOS, Lilian M.; MARINI, Janete A. S. Uso de estratégias de leitura por alunos do Ensino Médio. Paideia: Revista Cadernos de Psicologia e Educação, Ribeirão Preto, v. 34, p. 204-214, 2006.

KERBRAT-ORECCHIONI, Catherine. L'énonciation de la subjetivité dans le langage. Paris: Armand Colin, 1980.

KLEIMAN, Ângela. Oficina de Leitura - teoria e prática. Campinas: Pontes, 2013. 
KLEIMAN, Ângela B.; SEPULVEDA, Cida. Oficina de Gramática - metalinguagem para principiantes. Campinas, SP: Pontes, 2012.

LAMAS, Berenice Sica. O duplo em Lygia Fagundes Telles: um estudo em psicologia e literatura. Porto Alegre: EDIPUCRS, 2004.

LAPA, Manoel Rodrigues. Estilística da Língua Portuguesa. São Paulo: Martins Fontes, 1998.

LUCAS, Fábio. O conto Brasileiro Moderno. In: PROENÇA FILHO, Domício (org.). O Livro do Seminário. São Paulo: L.R., 1982.

LUCAS, Fábio. A ficção giratória de Lygia Fagundes Telles. Travessia, Florianópolis, n.20, p.60 - 77, 1990.

MARTINS, Nilce Sant'anna. Introdução à estilística: a expressividade na língua portuguesa. São Paulo: Editora da Universidade de São Paulo, 2012.

MICHELETTI, Guaraciaba. Enunciação e estilo: uma leitura dos contos $A$ caçada e Natal na barca, de Lygia Fagundes Telles. In: MICHELETTI, Guaraciaba (org.). Estudos de discurso e Estilo. São Paulo: Terracota, 2012.

MOISÉS, Massaud. A Criação Literária - Prosa I. São Paulo: Cultrix, 1967.

MONTEIRO, José Lemos. A Estilística. Petrópolis, RJ: Vozes, 2009.

PAES, José Paulo. Ao encontro dos desencontros. In: Cadernos de Literatura Brasileira: Lygia Fagundes Telles. São Paulo: Instituto Moreira Salles, 2002.

PASSOS, Cleusa Rios P. Breves Considerações sobre o Conto Moderno. In: BOSI, Viviana et. al. (orgs.). Fiç̧ões: Leitores e Leituras. São Paulo: Ateliê Editorial, 2001. RÉGIS, Sônia. A densidade do aparente. In: Cadernos de Literatura Brasileira: Lygia Fagundes Telles. São Paulo: Instituto Moreira Salles, 2002.

ROJO, Roxane. Letramento e capacidades de leitura para a cidadania. São Paulo: SEE: CENP, 2004.

ROJO, Roxane. Gêneros do discurso/texto como objeto de ensino de línguas: um retorno ao trivium?. In: Signori, Inês. (org.). [Re]discutir texto, gênero, discurso. São Paulo: Parábola Editorial, 2008.

SILVA, Vera Maria Tietzman. A metamorfose nos contos de Lygia Fagundes Telles. Rio de Janeiro:Presença: 1985.

SPENCER, John; GREGORY, Michael. Um enfoque do estudo do estilo. In: SPENCER, John (org.). Linguística e estilo. São Paulo: Cultrix e Editora da Universidade de São Paulo, 1974. 
TELLES, Lygia Fagundes. A caçada. In: Antes do baile verde. São Paulo: Companhia das Letras, 2009.

TELLES, Lygia Fagundes. Natal na barca. In: Antes do baile verde. São Paulo: Companhia das Letras, 2009.

TELLES, Lygia Fagundes. Verde lagarto amarelo. In: Antes do baile verde.

São Paulo: Companhia das Letras, 2009.

ULLMANN, Stephen. Semântica: uma introdução à ciência da significação. Lisboa: Fundação Calouste Gulbenkian, 1964.

WARTBURG, Walther Von; ULLMANN, Stephen. Problemas e métodos da linguística. São Paulo: Difel, 1975. 


\section{ANEXOS}

\section{Conto 1: A Caçada}

A loja de antiguidades tinha o cheiro de uma arca de sacristia com seus anos embolorados e livros comidos de traça. Com as pontas dos dedos, o homem tocou numa pilha de quadros. Uma mariposa levantou vôo e foi chocar-se contra uma imagem de mãos decepadas.

- Bonita imagem — disse ele.

A velha tirou um grampo do coque, e limpou a unha do polegar. Tornou a enfiar o grampo no cabelo.

- É um São Francisco.

Ele então voltou-se lentamente para a tapeçaria que tomava toda a parede no fundo da loja. Aproximou-se mais. A velha aproximou-se também.

— Já vi que o senhor se interessa mesmo é por isso... Pena que esteja nesse estado.

O homem estendeu a mão até a tapeçaria, mas não chegou a tocá-la.

— Parece que hoje está mais nítida...

— Nítida? - repetiu a velha, pondo os óculos. Deslizou a mão pela superfície puída. - Nítida, como?

- As cores estão mais vivas. A senhora passou alguma coisa nela?

A velha encarou-O. E baixou o olhar para a imagem de mãos decepadas. $O$ homem estava tão pálido e perplexo quanto a imagem.

- Não passei nada, imagine... Por que o senhor pergunta?

- Notei uma diferença.

- Não, não passei nada, essa tapeçaria não agüenta a mais leve escova, o senhor não vê? Acho que é a poeira que está sustentando o tecido acrescentou, tirando novamente o grampo da cabeça. Rodou-o entre os dedos com ar pensativo. Teve um muxoxo: - Foi um desconhecido que trouxe, precisava muito de dinheiro. Eu disse que o pano estava por demais estragado, que era difícil encontrar um 
comprador, mas ele insistiu tanto... Preguei aí na parede e aí ficou. Mas já faz anos isso. E o tal moço nunca mais me apareceu.

- Extraordinário...

A velha não sabia agora se o homem se referia à tapeçaria ou ao caso que acabara de the contar. Encolheu os ombros. Voltou a limpar as unhas com o grampo.

- Eu poderia vendê-la, mas quero ser franca, acho que não vale mesmo a pena. Na hora que se despregar, é capaz de cair em pedaços.

O homem acendeu um cigarro. Sua mão tremia. Em que tempo, meu Deus! em que tempo teria assistido a essa mesma cena. E onde?...

Era uma caçada. No primeiro plano, estava o caçador de arco retesado, apontando para uma touceira espessa. Num plano mais profundo, o segundo caçador espreitava por entre as árvores do bosque, mas esta era apenas uma vaga silhueta, cujo rosto se reduzira a um esmaecido contorno. Poderoso, absoluto era o primeiro caçador, a barba violenta como um bolo de serpentes, os músculos tensos, à espera de que a caça levantasse para desferir-lhe a seta.

O homem respirava com esforço. Vagou o olhar pela tapeçaria que tinha a cor esverdeada de um céu de tempestade. Envenenando o tom verde-musgo do tecido, destacavam-se manchas de um negro-violáceo e que pareciam escorrer da folhagem, deslizar pelas botas do caçador e espalhar-se no chão como um líquido maligno. A touceira na qual a caça estava escondida também tinha as mesmas manchas e que tanto podiam fazer parte do desenho como ser simples efeito do tempo devorando o pano.

- Parece que hoje tudo está mais próximo - disse o homem em voz baixa. -É como se... Mas não está diferente?

A velha firmou mais o olhar. Tirou os óculos e voltou a pô-los.

- Não vejo diferença nenhuma.

— Ontem não se podia ver se ele tinha ou não disparado a seta...

— Que seta? O senhor está vendo alguma seta?

— Aquele pontinho ali no arco... A velha suspirou.

- Mas esse não é um buraco de traça? Olha aí, a parede já está aparecendo, essas traças dão cabo de tudo - lamentou, disfarçando um bocejo. 
Afastou-se sem ruído, com suas chinelas de lã. Esboçou um gesto distraído: Fique aí à vontade, vou fazer meu chá.

O homem deixou cair o cigarro. Amassou-o devagarinho na sola do sapato. Apertou os maxilares numa contração dolorosa. Conhecia esse bosque, esse caçador, esse céu - conhecia tudo tão bem, mas tão bem! Quase sentia nas narinas o perfume dos eucaliptos, quase sentia morder-lhe a pele o frio úmido da madrugada, ah, essa madrugada! Quando? Percorrera aquela mesma vereda aspirara aquele mesmo vapor que baixava denso do céu verde... Ou subia do chão? O caçador de barba encaracolada parecia sorrir perversamente embuçado. Teria sido esse caçador? Ou o companheiro lá adiante, o homem sem cara espiando por entre as árvores? Uma personagem de tapeçaria. Mas qual? Fixou a touceira onde a caça estava escondida. Só folhas, só silêncio e folhas empastadas na sombra. Mas, detrás das folhas, através das manchas pressentia o vulto arquejante da caça. Compadeceu-se daquele ser em pânico, à espera de uma oportunidade para prosseguir fugindo. Tão próxima a morte! O mais leve movimento que fizesse, e a seta... A velha não a distinguira, ninguém poderia percebê-la, reduzida como estava a um pontinho carcomido, mais pálido do que um grão de pó em suspensão no arco.

Enxugando o suor das mãos, o homem recuou alguns passos. Vinha-Ihe agora uma certa paz, agora que sabia ter feito parte da caçada. Mas essa era uma paz sem vida, impregnada dos mesmos coágulos traiçoeiros da folhagem. Cerrou os olhos. E se tivesse sido o pintor que fez o quadro? Quase todas as antigas tapeçarias eram reproduções de quadros, pois não eram? Pintara o quadro original e por isso podia reproduzir, de olhos fechados, toda a cena nas suas minúcias: o contorno das árvores, o céu sombrio, o caçador de barba esgrouvinhada, só músculos e nervos apontando para a touceira... "Mas se detesto caçadas! Por que tenho que estar aí dentro?"

Apertou o lenço contra a boca. A náusea. Ah, se pudesse explicar toda essa familiaridade medonha, se pudesse ao menos... E se fosse um simples espectador casual, desses que olham e passam? Não era uma hipótese? Podia ainda ter visto o quadro no original, a caçada não passava de uma ficção. "Antes do aproveitamento da tapeçaria..." - murmurou, enxugando os vãos dos dedos no lenço.

Atirou a cabeça para trás como se o puxassem pelos cabelos, não, não ficara do lado de fora, mas lá dentro, encravado no cenário! E por que tudo parecia mais 
nítido do que na véspera, por que as cores estavam mais fortes apesar da penumbra? Por que o fascínio que se desprendia da paisagem vinha agora assim vigoroso, rejuvenescido?...

Saiu de cabeça baixa, as mãos cerradas no fundo dos bolsos. Parou meio ofegante na esquina. Sentiu o corpo moído, as pálpebras pesadas. E se fosse dormir? Mas sabia que não poderia dormir, desde já sentia a insônia a segui-lo na mesma marcação da sua sombra. Levantou a gola do paletó. Era real esse frio? Ou a lembrança do frio da tapeçaria? "Que loucura!... E não estou louco", concluiu num sorriso desamparado. Seria uma solução fácil. "Mas não estou louco.".

Vagou pelas ruas, entrou num cinema, saiu em seguida e quando deu acordo de si, estava diante da loja de antiguidades, o nariz achatado na vitrina, tentando vislumbrar a tapeçaria lá no fundo.

Quando chegou em casa, atirou-se de bruços na cama e ficou de olhos escancarados, fundidos na escuridão. A voz tremida da velha parecia vir de dentro do travesseiro, uma voz sem corpo, metida em chinelas de lã: "Que seta? Não estou vendo nenhuma seta..." Misturando-se à voz, veio vindo o murmurejo das traças em meio de risadinhas. $O$ algodão abafava as risadas que se entrelaçaram numa rede esverdinhada, compacta, apertando-se num tecido com manchas que escorreram até o limite da tarja. Viu-se enredado nos fios e quis fugir, mas a tarja o aprisionou nos seus braços. No fundo, lá no fundo do fosso, podia distinguir as serpentes enleadas num nó verde-negro. Apalpou o queixo. "Sou o caçador?" Mas ao invés da barba encontrou a viscosidade do sangue.

Acordou com o próprio grito que se estendeu dentro da madrugada. Enxugou o rosto molhado de suor. Ah, aquele calor e aquele frio! Enrolou-se nos lençóis. E se fosse o artesão que trabalhou na tapeçaria? Podia revê-la, tão nítida, tão próxima que, se estendesse a mão, despertaria a, folhagem. Fechou os punhos. Haveria de destruí-la, não era verdade que além daquele trapo detestável havia alguma coisa mais, tudo não passava de um retângulo de pano sustentado pela poeira. Bastava soprá-la, soprá-la!

Encontrou a velha na porta da loja. Sorriu irônica:

- Hoje o senhor madrugou.

- A senhora deve estar estranhando, mas... 
- Já não estranho mais nada, moço. Pode entrar, pode entrar, o senhor conhece o caminho...

"Conheço o caminho" - murmurou, seguindo lívido por entre os móveis. Parou. Dilatou as narinas. E aquele cheiro de folhagem e terra, de onde vinha aquele cheiro? E por que a loja foi ficando embaçada, lá longe? Imensa, real só a tapeçaria a se alastrar sorrateiramente pelo chão, pelo teto, engolindo tudo com suas manchas esverdinhadas. Quis retroceder, agarrou-se a um armário, cambaleou resistindo ainda e estendeu os braços até a coluna. Seus dedos afundaram por entre galhos e resvalaram pelo tronco de uma árvore, não era uma coluna, era uma árvore! Lançou em volta um olhar esgazeado: penetrara na tapeçaria, estava dentro do bosque, os pés pesados de lama, os cabelos empastados de orvalho. Em redor, tudo parado. Estático. No silêncio da madrugada, nem o piar de um pássaro, nem o farfalhar de uma folha. Inclinou-se arquejante. Era o caçador? Ou a caça? Não importava, não importava, sabia apenas que tinha que prosseguir correndo sem parar por entre as árvores, caçando ou sendo caçado. Ou sendo caçado?... Comprimiu as palmas das mãos contra a cara esbraseada, enxugou no punho da camisa o suor que lhe escorria pelo pescoço. Vertia sangue o lábio gretado.

Abriu a boca. E lembrou-se. Gritou e mergulhou numa touceira. Ouviu o assobio da seta varando a folhagem, a dor!

"Não..." - gemeu, de joelhos. Tentou ainda agarrar-se à tapeçaria. E rolou encolhido, as mãos apertando o coração. 


\section{Conto 2: Verde Lagarto Amarelo}

Ele entrou no seu passo macio, sem ruído, não chegava a ser felino: apenas um andar discreto. Polido.

- Rodolfo! Onde está você?... Dormindo? - perguntou quando me viu levantar da poltrona e vestir a camisa. Baixou o tom de voz. - Está sozinho?

Ele sabe muito bem que estou sozinho, ele sabe que sempre estou sozinho.

- Estava lendo.

- Dostoievski?

Fechei o livro e nãopude deixar de sorrir. Nada lhe escapava.

- Queria lembrar uma certa passagem... Só que está quente demais, acho que este é o dia mais quente desde que começou o verão.

Ele deixou a pasta na cadeira e abriu o pacote de uvas roxas.

- Estavam tão maduras, olha só que beleza - disse tirando um cacho e balançando-o no ar como um pêndulo. - Prova! Uma delícia.

Com um gesto casual, atirei meu paletó em cima da mesa, cobrindo o rascunho de um conto que começara naquela manhã.

- Já é tempo de uvas? - perguntei colhendo um bago.

Era enjoativo de tão doce mas se eu rompesse a polpa cerrada e densa, sentiria seu gosto verdadeiro. Com a ponta da língua pude sentir a semente apontando sob a polpa. Varei-a. O sumo ácido inundou-me a boca. Cuspi a semente: assim queria escrever, indo ao âmago do âmago até atingir a semente resguardada lá no fundo como um feto.

- Trouxe também uma coisa... Mostro depois.

Encarei-o. Quando ele sorria ficava menino outra vez. Seus olhos tinham o mesmo brilho úmido das uvas.

- Que coisa?

- Mas se eu já disse que é surpresa! Mostro depois.

Não insisti. Conhecia de sobra aquela antiga expressão com que vinha me anunciar que tinha algo escondido no bolso ou debaixo do travesseiro. Acabava sempre por me oferecer seu tesouro: a maçã, o cigarro, a revistinha pornográfica, o 
pacote de suspiros, mas antes ficava algum tempo me rondando com esse ar de secreto deslumbramento.

- Vou fazer um café - anunciei.

- Só se for para você, tomei há pouco na esquina.

Era mentira. O bar da esquina era imundo e para ele o café fazia parte de um ritual nobre, limpo. Dizia isso para me poupar, estava sempre querendo me poupar.

- Na esquina?

- Quando comprei as uvas...

Meu irmão. O cabelo louro, a pele bronzeada de sol, as mãos de estátua. E aquela cor nas pupilas.

- Mamãe achava que seus olhos eram cor-de-violeta.

- Cor-de-violeta?

- Foi o que ela disse à tia Débora, meu filho Eduardo tem os olhos cor-devioleta.

Ele tirou o paletó. Afrouxou a gravata.

- Como é que são olhos cor-de-violeta?

- Cor-de-violeta - eu respondi abrindo o fogareiro.

Ele riu apalpando os bolsos do paletó até encontrar o cigarro.

- Meu Deus, tinha um canteiro de violetas no jardim de casa... Não eram violetas, Rodolfo?

- Eram violetas.

- E uma parreira, lembra? Nunca conseguimos um cacho maduro daquela parreira - disse amarfanhando com um gesto afetuoso o papel das uvas. - Até hoje não sei se eram doces. Eram doces?

- Também não sei, você não esperava amadurecer.

Vagarosamente ele tirou as abotoaduras e foi dobrando a manga da camisa com aquela arte toda especial que tinha de dobrá-la sem fazer rugas, na exata medida do punho. Os braços musculosos de nadador. Os pêlos dourados. Fiquei a olhar as abotoaduras que tinham sido do meu pai.

- A Ofélia quer que você almoce domingo com a gente. Ela releu seu romance e ficou no maior entusiasmo, gostou ainda mais do que da primeira vez, você precisa ver com que interesse analisou as personagens, discutiu os detalhes...

- Domingo já tenho um compromisso - eu disse enchendo a chaleira de água. 
- E sábado? Não me diga que sábado você também não pode.

Aproximei-me da janela. O sopro do vento era ardente como se a casa estivesse no meio de um braseiro. Respirei de boca aberta agora que ele não me via, agora que eu podia amarfanhar a cara como ele amarfanhara o papel. Esfreguei nela o lenço, até quando, até quando?!... E me trazia a infância, será que ele não vê que para mim foi só sofrimento? Por que não me deixa em paz, por quê? Por que tem de vir aqui e ficar me espetando, não quero lembrar nada, não quero saber de nada! Fecho os olhos. Está amanhecendo e o sol está longe, tem brisa na campina, cascata, orvalho gelado deslizando na corola, chuva fina no meu cabelo, a montanha e o vento, todos os ventos soprando. Os ventos! Vazio. Imobilidade e vazio. Se eu ficar assim imóvel, respirando leve, sem ódio, sem amor, se eu ficar assim um instante, sem pensamento, sem corpo...

- E sábado? Ela quer fazer aquela torta de nozes que você adora.

- Cortei o açúcar, Eduardo.

- Mas saia um pouco do regime, você emagreceu, não emagreceu?

- Ao contrário, engordei. Não está vendo? Estou enorme.

- Não é possível! Assim de costas você me pareceu tão mais magro, palavra que eu já ia perguntar quantos quilos você perdeu.

Agora a camisa se colava ao meu corpo. Limpei as mãos viscosas no peitoril da janela e abri os olhos que ardiam, o sal do suor é mais violento do que o sal das lágrimas. "Esse menino transpira tanto, meus céus! Acaba de vestir roupa limpa e já começa a transpirar, nem parece que tomou banho. Tão desagradável!..." Minha mãe não usava a palavra suor que era forte demais para seu vocabulário, ela gostava das belas palavras. Das belas imagens. Delicadamente falava em transpiração com aquela elegância em vestir as palavras como nos vestia. Com a diferença que Eduardo se conservava limpo como se estivesse numa redoma, as mãos sem poeira, a pele fresca. Podia rolar na terra e não se conspurcava, nada chegava a sujá-lo realmente porque mesmo através da sujeira podia se ver que estava intacto. Eu não. Com a maior facilidade me corrompia lustroso e gordo, o suor a escorrer pelo pescoço, pelos sovacos, pelo meio das pernas. Não queria suar, não queria, mas o suor medonho não parava de escorrer manchando a camisa de amarelo com uma borda esverdinhada, suor de bicho venenoso, traiçoeiro, malsão. Enxugava depressa a testa, o pescoço, tentava num último esforço salvar 
ao menos a camisa. Mas a camisa já era uma pele enrugada aderindo à minha com meu cheiro, com a minha cor. Era menino ainda mas houve um dia em que quis morrer para não transpirar mais.

- Na noite passada sonhei com nossa antiga casa - disse ele aproximando-se do fogareiro. Destapou a chaleira, espiou dentro. - Não me lembro bem mas parece que a casa estava abandonada, foi um sonho estranho...

- Também sonhei com a casa mas já faz tempo - eu disse.

Ele aproximou-se. Esquivei-me em direção ao armário. Tirei as xícaras.

- Mamãe apareceu no seu sonho? - perguntou ele.

- Apareceu. O pai tocava piano e mamãe...

Rodopiávamos vertiginosos numa valsa e eu era magro, tão magro que meus pés mal roçavam o chão, senti mesmo que levantavam vôo e eu ria enlaçando-a em volta do lustre quando de repente o suor começou a escorrer, escorrer.

- Ela estava viva?

Seu vestido branco se empapava do meu suor amarelo-verde mas ela continuava dançando, desligada, remota.

- Estava viva, Rodolfo?

- Não, era uma valsa póstuma - eu disse colocando na frente dele a xícara perfeita. Reservei para mim a que estava rachada. - Está reconhecendo essa xícara?

Ele tomou-a pela asa. Examinou-a. Sua fisionomia se iluminou com a graça de um vitral varado pelo sol.

- Ah!... as xicrinhas japonesas. Sobraram muitas ainda?

O aparelho de chá, o faqueiro, os cristais e os tapetes tinham ficado com ele. Também os lençóis bordados, obriguei-o a aceitar tudo. Ele recusava, chegou a se exaltar, "não quero, não é justo, não quero! Ou você fica com a metade ou então não aceito nada! Amanhã você pode se casar também..." Nunca, respondi. Moro só, gosto da casa sem nenhum enfeite, quanto mais simples melhor. Ele parecia não ouvir uma só palavra enquanto ia amontoando os objetos em duas porções, "Olha, isto você leva que estava no seu quarto..." Tive de recorrer à violência. Se você teimar em me deixar essas coisas, assim que você virar as costas jogo tudo na rua! Cheguei a agarrar uma jarra, no meio da rua! Ele empalideceu, os lábios trêmulos. "Você jamais faria isso, Rodolfo. Cale-se, por favor, que você não sabe o que está 
dizendo." Passei as mãos na cara ardente. E a voz da minha mãe vindo das cinzas: "Rodolfo, por que você há de entristecer seu irmão? Não vê que ele está sofrendo? Por que você faz assim?!". Abracei-o. Ouça Eduardo, sou um tipo mesmo esquisito, você está farto de saber que sou meio louco. Não quero mesmo nada, não sei explicar mas não quero, está me entendendo? Leve tudo à Ofélia, presente meu. Não posso dar a vocês um presente de casamento? Para não dizer que não fico com nada, olha... está aqui, pronto, fico com essas xícaras!

- Finas como casca de ovo - disse ele batendo com a unha na porcelana. Ficavam na prateleira do armário rosado, lembra? Esse armário está na nossa saleta.

Despejei água fervente na caneca. O pó de café foi se diluindo resistente, difícil. Minha mãe. Depois, Ofélia. Por que não haveria de ficar também com os lençóis?

- E Ofélia? Para quando o filho?

Ele apanhou a pilha de jornais velhos que estavam no chão, ajeitou-a cuidadosamente e esboçou um gesto de procura, devia estar sentindo falta de um lugar certo para serem guardados os jornais já lidos. Teve uma expressão de resignado bom humor, mas então a desordem do apartamento comportava um móvel assim supérfluo? Enfiou a pilha na prateleira da estante e voltou-se para mim. Ficou me seguindo com o olhar enquanto eu procurava no armário debaixo da pia a lata onde devia estar o açúcar. Uma barata fugiu atarantada, escondendo-se debaixo de uma tampa de panela e logo uma outra maior se despencou não sei de onde e tentou também o mesmo esconderijo. Mas a fresta era estreita demais e ela mal conseguiu esconder a cabeça, ah, o mesmo humano desespero na procura de um abrigo. Abri a lata de açúcar e esperei que ele dissesse que havia um novo sistema de acabar com as baratas, era facílimo, bastava chamar pelo telefone e já aparecia o homem de farda cáqui e bomba em punho e num segundo pulverizava tudo. Tinha em casa o número do telefone, podia me dar, nem baratas nem formigas.

- No próximo mês, parece. Está tão lépida que nem acredito que esteja nas vésperas - disse ele me contornando pelas costas. Não perdia um só dos meus movimentos. - E adivinha agora quem vai ser o padrinho.

- Que padrinho? 
- Do meu filho, ora!

- Não tenho a menor idéia.

- Você.

Minha mão tremia como se ao invés de açúcar eu estivesse mergulhando acolher em arsênico. Senti-me infinitamente mais gordo. Mais vil. Tive vontade de vomitar.

- Não faz sentido, Eduardo. Não acredito em Deus, não acredito em nada.

- E daí? - perguntou ele, servindo-se de mais açúcar. Atraiu-me quase num abraço. - Fique tranquilo, eu acredito por nós dois.

Tomei de um só trago o café amargo. Uma gota de suor pingou no pires. Passei a mão pelo queixo. Não pudera ser pai, seria padrinho. Não era um ser amável? Um casal amabilíssimo. A pretexto de aquecer o café, fiquei de costas e então esfreguei furtivamente o pano de prato na cara.

- Era essa a surpresa? - perguntei e ele olhou-me com inocência. Repeti a pergunta: - A surpresa! Quando chegou você disse que...

- Ah!... não, não! Não é isso não - exclamou e riu apertando os olhos queriam também com uma ponta de malícia. - A surpresa é outra. Se der certo, Rodolfo, se der certo!... Enfim, você é quem vai decidir. Ponho nas suas mãos.

Era exatamente a expressão da minha mãe quando vinha me preparar para uma boa notícia. Rondava, rondava e ficava observando-me reticente, saboreando o segredo até o momento em que não resistia mais e contava. A condição era invariável: "Mas você vai me prometer que não vai comer nenhum doce durante uma semana, só uma semana!"

E se ele fosse morar longe? Podia se mudar de cidade, viajar. Mas não. Precisava ficar por perto, sempre em redor, me olhando. Desde pequeno, no berço já me olhava assim. Não precisaria me odiar, eu nem pediria tanto, bastava me ignorar, se ao menos me ignorasse. Era bonito, inteligente, amado, conseguiu sempre fazer tudo muito melhor do que eu, melhor do que os outros, em suas mãos as menores coisas adquiriam outra importância, como que se renovavam. E então? Natural que esquecesse o irmão obeso, mal vestido, malcheiroso. Escritor, sim, mas nem aquele tipo de escritor de sucesso, convidado para festas, dando entrevistas na televisão: um escritor de cabeça baixa e calado, abrindo com as mãos em garra seu caminho. Se ao menos ele... mas não, claro que não, desde menino eu já estava 
condenado ao seu fraterno amor. Às vezes, escondia-me no porão, corria para o quintal, subia na figueira, ficava imóvel, um lagarto no vão do muro, pronto, agora não vai me achar. Mas ele abria portas, vasculhava armários, abria a folhagem e ficava rindo por entre lágrimas. Engatinhava ainda quando saía à minha procura, farejando meu rastro. "Rodolfo, não faça seu irmãozinho chorar, não quero que ele fique triste!" Para que ele não ficasse triste, só eu soube que ela ia morrer. "Você já é grande, você deve saber a verdade" disse meu pai olhando reto nos meus olhos. "É que sua mãe não tem nem..." Não completou a frase. Voltou-se para a parede e ali ficou de braços cruzados, os ombros curvos. "Só eu e você sabemos. Ela desconfia mas de jeito nenhum quer que seu irmãozinho saiba, está entendendo?" Eu entendia. Na,sua última festa de aniversário ficamos reunidos em redor da cama. "Laura é como o rei daquela história" disse meu pai, dando-lhe de beber um gole de vinho. "Só que ao invés de transformar tudo em ouro, quando toca nas coisas, transforma tudo em beleza." Com os olhos cozidos de tanto chorar, ajoelhei-me e fingindo arrumar-Ihe o travesseiro, pousei a cabeça ao alcance da sua mão, ah, se me tocas-se com um pouco de amor. Mas ela só via o broche, um caco de vidro que Eduardo achou no quintal e enrolou em fiozinhos de arame formando um casulo, "mamãezinha querida, eu que fiz para você!" Ela beijou o broche. E o arame ficou sendo prata e o caco de garrafa ficou sendo esmeralda. Foi o broche que the fechou a gola do vestido. Quando me despedi, apertei sua mão gelada contra minha boca, e eu, mamãe, e eu?...

- Esqueci de oferecer biscoitos, olha aí, você gosta - eu disse tirando a lata do armário.

- É sua empregada quem faz?

- Minha empregada só vem uma vez por semana, comprei na rua acrescentei e lancei-Ihe um olhar. Que surpresa era essa agora? O que é que eu devia decidir? Eu devia decidir, ele disse. Mas o quê?... Interpelei-o: - Que é que você está escondendo, Eduardo? Não vai me dizer?

Ele pareceu não ter ouvido uma só palavra. Quebrou a cinza do cigarro no cinzeiro, soprou o pouco que the caiu na calça e inclinou-se para os biscoitos.

- Ah!... rosquinhas. Ofélia aprendeu a fazer sequilhos no caderno de receitas da mamãe mas estão longe de ser como aqueles. 
Ele comia sequilhos quando entrei no quarto. Ao lado, a caneca de chocolate fumegante. Eu tinha tomado chá. Chá. Dei uma volta em redor dele. O Júlio já está na esquina esperando, avisei. Veio me dizer que tem de ser agora. Ele então se levantou, calçou a sandália, tirou o relógio de pulso e a correntinha do pescoço. Dirigiu-se para aporta com uma firmeza que me espantou. Vi-o ensanguentado, a roupa em tiras. Você é menor, Eduardo, você vai apanhar feito cachorro! Ele abriu os braços. "E daí? Quer que a turma me chame de covarde?" Sentei-me na cadeira onde ele estivera e ali fiquei encolhido, tomando o seu chocolate e comendo sequilhos. Tinha a boca cheia quando ouvi a voz da minha mãe chamando:"Rodolfo, Rodolfo!" Agora ela o carregava em prantos, tentando arrancar-lhe o canivete enterrado no peito até o cabo.

- Procurei seu romance em duas livrarias e não encontrei, queria dar a uns amigos. Está esgotado, Rodolfo? O vendedor disse que vende demais.

- Exagero. Talvez se esgote mas não já.

A boca cheia de sequilhos e o suor escorrendo por todos os poros, escorrendo. A voz da minha mãe insistiu enérgica: "Rodolfo, você está me ouvindo? Onde está o Eduardo?!" Entrei no quarto dela. Estava deitada, bordando. Assim que me viu, sua fisionomia se confrangeu. Deixou o bordado e ficou balançando a cabeça. "Mas filho, comendo de novo?! Quer engordar mais ainda?..." - Suspirou, dolorida. "Onde está seu irmão?" Encolhi os ombros, não sei, não sou pajem dele. Ela ficou me olhando. "Essa é maneira de me responder, Rodolfo? Hein?!..." Desci a escada comendo o resto dos sequilhos que escondi nos bolsos. O silêncio me seguiu descendo a escada degrau por degrau, colado ao chão, viscoso, pesado. Parei de mastigar. E de repente me precipitei pela rua afora, eu o queria vivo, o canivete não! Encontrei-o sentado na sarjeta, a camisa rasgada, um arranhão fundo na testa. Sorriu palidamente. Ofegava. Júlio tinha acabado de fugir. Cravei o olhar no seu peito. Mas ele não usou o canivete? perguntei. Apoiando-se na árvore, levantouse com dificuldade, tinha torcido o pé. "Que canivete?..." Baixando a cabeça que latejava, inclinei-me até o chão. Você não pode andar, eu disse, apoiando as mãos nos joelhos. Vamos, monta em mim. Ele obedeceu. Estranhei; era tão magro, não era? Mas pesava como chumbo. $O$ sol batia em cheio em nós enquanto o vento levantava as tiras da sua camisa rasgada. Vi nossa sombra no muro, as tiras se 
abrindo como asas. Enlaçou-me mais fortemente, encostou o queixo no meu ombro e teve um breve soluço, "que bom que você veio me buscar..."

- Seu novo romance? - perguntou ele na maior excitação. Encontrara o rascunho em cima da mesa. - Posso ler, Rodolfo? Posso?

Tirei-lhe as folhas das mãos e fechei-as na gaveta. Era o que me restara: escrever. Será possível que ele também?...

- Não, não é possível, Eduardo - eu disse, tentando abrandar a voz. - Está tudo muito no início, trabalho mal no calor - acrescentei meio distraidamente.

Olhei para sua pasta na cadeira e adivinhei a surpresa. Senti meu coração se fechar como uma concha. A dor era quase física. Olhei para ele. - Você escreveu um romance. É isso? Os originais estão na pasta... É isso?

Ele então abriu a pasta. 


\section{Conto 3: Natal na Barca}

Não quero nem devo lembrar aqui por que me encontrava naquela barca. Só sei que em redor tudo era silêncio e treva. $\mathrm{E}$ que me sentia bem naquela solidão. $\mathrm{Na}$ embarcação desconfortável, tosca, apenas quatro passageiros. Uma lanterna nos iluminava com sua luz vacilante: um velho, uma mulher com uma criança e eu.

O velho, um bêbado esfarrapado, deitara-se de comprido no banco, dirigira palavras amenas a um vizinho invisível e agora dormia. A mulher estava sentada entre nós, apertando nos braços a criança enrolada em panos. Era uma mulher jovem e pálida. O longo manto escuro que lhe cobria a cabeça dava-lhe o aspecto de uma figura antiga.

Pensei em falar-Ihe assim que entrei na barca. Mas já devíamos estar quase no fim da viagem e até aquele instante não me ocorrera dizer-lhe qualquer palavra. Nem combinava mesmo com uma barca tão despojada, tão sem artifícios, a ociosidade de um diálogo. Estávamos sós. E o melhor ainda era não fazer nada, não dizer nada, apenas olhar o sulco negro que a embarcação ia fazendo no rio.

Debrucei-me na grade de madeira carcomida. Acendi um cigarro. Ali estávamos os quatro, silenciosos como mortos num antigo barco de mortos deslizando na escuridão. Contudo, estávamos vivos. E era Natal.

A caixa de fósforos escapou-me das mãos e quase resvalou para o. rio. Agachei-me para apanhá-la. Sentindo então alguns respingos no rosto, inclinei-me mais até mergulhar as pontas dos dedos na água.

- Tão gelada - estranhei, enxugando a mão.

- Mas de manhã é quente.

Voltei-me para a mulher que embalava a criança e me observava com um meio sorriso. Sentei-me no banco ao seu lado. Tinha belos olhos claros, extraordinariamente brilhantes. Reparei que suas roupas (pobres roupas puídas) tinham muito caráter, revestidas de uma certa dignidade.

— De manhã esse rio é quente - insistiu ela, me encarando.

- Quente? 
- Quente e verde, tão verde que a primeira vez que lavei nele uma peça de roupa pensei que a roupa fosse sair esverdeada. É a primeira vez que vem por estas bandas?

Desviei o olhar para o chão de largas tábuas gastas. E respondi com uma outra pergunta:

- Mas a senhora mora aqui perto?

- Em Lucena. Já tomei esta barca não sei quantas vezes, mas não esperava que justamente hoje...

A criança agitou-se, choramingando. A mulher apertou-a mais contra o peito. Cobriu-Ihe a cabeça com o xale e pôs-se a niná-la com um brando movimento de cadeira de balanço. Suas mãos destacavam-se exaltadas sobre o xale preto, mas 0 rosto era sereno.

- Seu filho?

- É. Está doente, vou ao especialista, o farmacêutico de Lucena achou que eu devia ver um médico hoje mesmo. Ainda ontem ele estava bem mas piorou de repente. Uma febre, só febre... Mas Deus não vai me abandonar.

-É o caçula?

Levantou a cabeça com energia. O queixo agudo era altivo mas o olhar tinha a expressão doce.

- É o único. O meu primeiro morreu o ano passado. Subiu no muro, estava brincando de mágico quando de repente avisou, vou voar! E atirou-se. A queda não foi grande, o muro não era alto, mas caiu de tal jeito... Tinha pouco mais de quatro anos.

Joguei o cigarro na direção do rio e o toco bateu na grade, voltou e veio rolando aceso pelo chão. Alcancei-o com a ponta do sapato e fiquei a esfregá-lo devagar. Era preciso desviar o assunto para aquele filho que estava ali, doente, embora. Mas vivo.

- E esse? Que idade tem?

- Vai completar um ano. - E, noutro tom, inclinando a cabeça para o ombro: - Era um menino tão alegre. Tinha verdadeira mania com mágicas. Claro que não saía nada, mas era muito engraçado... A última mágica que fez foi perfeita, vou voar! disse abrindo os braços. E voou. 
Levantei-me. Eu queria ficar só naquela noite, sem lembranças, sem piedade. Mas os laços (os tais laços humanos) já ameaçavam me envolver. Conseguira evitálos até aquele instante. E agora não tinha forças para rompê-los.

- Seu marido está à sua espera?

- Meu marido me abandonou.

Sentei-me e tive vontade de rir. Incrível. Fora uma loucura fazer a primeira pergunta porque agora não podia mais parar, ah! aquele sistema dos vasos comunicantes.

— Há muito tempo? Que seu marido...

— Faz uns seis meses. Vivíamos tão bem, mas tão bem. Foi quando ele encontrou por acaso essa antiga namorada, me falou nela fazendo uma brincadeira, a Bila enfeiou, sabe que de nós dois fui eu que acabei ficando mais bonito? Não tocou mais no assunto. Uma manhã ele se levantou como todas as manhãs, tomou café, leu o jornal, brincou com o menino e foi trabalhar. Antes de sair ainda fez assim com a mão, eu estava na cozinha lavando a louça e ele me deu um adeus através da tela de arame da porta, me lembro até que eu quis abrir a porta, não gosto de ver ninguém falar comigo com aquela tela no meio... Mas eu estava com a mão molhada. Recebi a carta de tardinha, ele mandou uma carta. Fui morar com minha mãe numa casa que alugamos perto da minha escolinha. Sou professora.

Olhei as nuvens tumultuadas que corriam na mesma direção do rio. Incrível. la contando as sucessivas desgraças com tamanha calma, num tom de quem relata fatos sem ter realmente participado deles. Como se não bastasse a pobreza que espiava pelos remendos da sua roupa, perdera o filhinho, o marido, via pairar uma sombra sobre o segundo filho que ninava nos braços. E ali estava sem a menor revolta, confiante. Apatia? Não, não podiam ser de uma apática aqueles olhos vivíssimos, aquelas mãos enérgicas. Inconsciência? Uma certa irritação me fez andar.

- A senhora é conformada.

- Tenho fé, dona. Deus nunca me abandonou.

- Deus - repeti vagamente.

- A senhora não acredita em Deus? 
- Acredito - murmurei. E ao ouvir o som débil da minha afirmativa, sem saber por quê, perturbei-me. Agora entendia. Aí estava o segredo daquela segurança, daquela calma. Era a tal fé que removia montanhas...

Ela mudou a posição da criança, passando-a do ombro direito para o esquerdo. E começou com voz quente de paixão:

- Foi logo depois da morte do meu menino. Acordei uma noite tão desesperada que saí pela rua afora, enfiei um casaco e saí descalça e chorando feito louca, chamando por ele! Sentei num banco do jardim onde toda tarde ele ia brincar. E fiquei pedindo, pedindo com tamanha força, que ele, que gostava tanto de mágica, fizesse essa mágica de me aparecer só mais uma vez, não precisava ficar, se mostrasse só um instante, ao menos mais uma vez, só mais uma! Quando fiquei sem lágrimas, encostei a cabeça no banco e não sei como dormi. Então sonhei e no sonho Deus me apareceu, quer dizer, senti que ele pegava na minha mão com sua mão de luz. E vi o meu menino brincando com o Menino Jesus no jardim do Paraíso. Assim que ele me viu, parou de brincar e veio rindo ao meu encontro e me beijou tanto, tanto... Era tamanha sua alegria que acordei rindo também, com o sol batendo em mim.

Fiquei sem saber o que dizer. Esbocei um gesto e em seguida, apenas para fazer alguma coisa, levantei a ponta do xale que cobria a cabeça da criança. Deixei cair o xale novamente e voltei-me para o rio. O menino estava morto. Entrelacei as mãos para dominar o tremor que me sacudiu. Estava morto. A mãe continuava a niná-lo, apertando-o contra o peito. Mas ele estava morto.

Debrucei-me na grade da barca e respirei penosamente: era como se estivesse mergulhada até o pescoço naquela água. Senti que a mulher se agitou atrás de mim

- Estamos chegando - anunciou.

Apanhei depressa minha pasta. $O$ importante agora era sair, fugir antes que ela descobrisse, correr para longe daquele horror. Diminuindo a marcha, a barca fazia uma larga curva antes de atracar. O bilheteiro apareceu e pôs-se a sacudir o velho que dormia:

— Chegamos!... Ei! chegamos!

Aproximei-me evitando encará-la. 
- Acho melhor nos despedirmos aqui — disse atropeladamente, estendendo a mão.

Ela pareceu não notar meu gesto. Levantou-se e fez um movimento como se fosse apanhar a sacola. Ajudei-a, mas ao invés de apanhar a sacola que Ihe estendi, antes mesmo que eu pudesse impedi-lo, afastou o xale que cobria a cabeça do filho.

- Acordou o dorminhoco! E olha aí, deve estar agora sem nenhuma febre.

- Acordou?!

Ela sorriu:

- Veja...

Inclinei-me. A criança abrira os olhos - aqueles olhos que eu vira cerrados tão definitivamente. E bocejava, esfregando a mãozinha na face corada. Fiquei olhando sem conseguir falar.

— Então, bom Natal! — disse ela, enfiando a sacola no braço.

Sob o manto preto, de pontas cruzadas e atiradas para trás, seu rosto resplandecia. Apertei-Ihe a mão vigorosa e acompanhei-a com o olhar até que ela desapareceu na noite.

Conduzido pelo bilheteiro, o velho passou por mim retomando seu afetuoso diálogo com o vizinho invisível. Saí por último da barca. Duas vezes voltei-me ainda para ver o rio. E pude imaginá-lo como seria de manhã cedo: verde e quente. Verde e quente. 